UNIVERSIDADE DE SÃO PAULO

FACULDADE DE FILOSOFIA, LETRAS E CIÊNCIAS HUMANAS

DEPARTAMENTO DE LETRAS ORIENTAIS

PROGRAMA DE PÓS GRADUAÇÃO EM LITERATURA E CULTURA RUSSA

Uma aventura: o teatro de Marina Tsvetáieva

Tradução e apresentação

Raquel Arantes Toledo Caregaro

São Paulo

2015 
UNIVERSIDADE DE SÃO PAULO

FACULDADE DE FILOSOFIA, LETRAS E CIÊNCIAS HUMANAS

DEPARTAMENTO DE LETRAS ORIENTAIS

PROGRAMA DE PÓS GRADUAÇÃO EM LITERATURA E CULTURA RUSSA

Raquel Arantes Toledo Caregaro

\section{Uma aventura: o teatro de Marina Tsvetáieva Tradução e apresentação}

Dissertação apresentada no Programa de PósGraduação em Literatura e Cultura Russa, do Departamento de Letras Orientais da Faculdade de Filosofia, Letras e Ciências Humanas da Universidade de São Paulo, para a obtenção do título de Mestre em Letras.

Orientadora: Prof. ${ }^{\mathrm{a}}$ Dr. ${ }^{\mathrm{a}}$ Arlete Orlando Cavaliere

São Paulo 
À Rebeca, pelo amor aos livros.

Ao Dario, pela maior parceria que eu poderia encontrar. 


\section{Agradecimentos}

Antes de tudo, quero agradecer a Deus, pela fé e pelo amor. Pela inspiração e pela superação de cada desafio pessoal que a dissertação me proporcionou.

Agradeço à minha mãe e ao meu pai por sempre me apoiarem e sempre me apresentarem aos amigos como a filha estudiosa (o que bem sei que não tão verdade, assim). Por mesmo sem entenderem exatamente o que o mestrado significa para mim, sempre se orgulharam e, assim, me motivaram. Agradeço aos meus irmãos. À Rebeca pela inspiração, à Rayana, que tanto me motivou com seu trabalho de conclusão de curso e ao José, que me fascina ao me mostra que a vida se abre novamente, agora diante dele.

Ao Marcos, à Ana, à Tatiana e, especilamente, à Tarahmis que tantas vezes não puderam contar comigo em reuniões familiares mas que sempre souberam que era nescessário para que eu realizasse esse sonho. Obrigada pelo amor e pela torcida.

Agradeço aos meus amigos queridos, com quem sempre pude dividir minhas angustias e que sempre me ajudaram a sorrir: Giovanna, Guilherme, Junior, Marcelo e Luca. Obrigada por nunca terem duvidado que eu conseguiria. Agradeço à Andressa, à Larissa, ao Felippe e ao Guilherme pela presença sempre oportuna e pela amizade tão pronfunda e reconfortante. Agradeço às minhas companheiras de anos de Letras, que hoje são, claro, muito, muito mais que isso. São memórias que levo comigo e promessas de ainda mais risadas futuras. Minhas amigas-vizinhas para todas as horas (principalmente às de desespero!): Louise, Jessika, Carolina e especialmente e com enorme gratidão à Natália, que revisou com tanto esmero o texto que aqui apresento. Ao Antônio, meu muito obrigada por tantas dicas e compras da Amazon divididas - e especialmente pela ajuda com o abstract, ufa! -; à Rafaela, por sempre se importar, sempre socorrer e sempre me ajudar a dizer o que eu insisto em guardar; à Livia pela companhia em absolutamente tudo, pelo apoio, pelas lágrimas e risadas que sempre dividimos. Aos meus queridos da Cosac Naify: Miguel, Livia D., Florencia, Heloisa, Marta, Gabriela, Milton e Paulo, que sempre partilharam comigo suas visões da Rússia e suas palavras de apoio; agradeço em particular à Letícia, sempre tão paciente. Agradeço à Eloah por tudo que dividimos, em especial o amor pela Rússia. 
Obrigada aos meus pastores e irmãos da Igreja Presbiteriana Jardim das Oliveiras que sempre oraram por mim e por minha família.

Meu obrigada mais do que essencial ao Rafael Falasco que me acompanhou de perto na redação de cada capítulo, de cada nota, de cada subtítulo, me ajudando a organizar meus horários, minha produtividade e me ajudando a primorar meu texto. Obrigada por se importar, por se empolgar e por me motivar. Seria muito mais sofrido sem você.

Agradeço aos professores da banca examinadora por lerem e avalierem meu trabalho. Agradeço à professora Denise pelas aulas particulares de russo, tão fundamentais. Agradeço à professora Aurora Bernadini, não só por seu precioso trabalho nos estudos pioneiros sobre Tsvetáieva, que além de serem fontes preciosas para a dissertação, me deram momentos de felicidade e realização, e também por suas críticas tão construtivas na banca de qualificação; é um privilégio contar com sua opinião. Agradeço a amizade e o carinho que recebi de Yulia Mikaelyan, além de toda a ajuda com o russo. Orgulho-me de nossa amizade.

Não tenho como terminar esses agradecimentos sem mencionar meus queridos professores do curso de russo, que tanto me marcaram com seus talentos: Noé, Elena, Homero, Bruno e Mário (tão fundamental na minha qualificação!). E, claro, agradeço de todo coração à minha querida orientadora, professora Arlete, que sempre me acolheu de forma calorosa e que sempre me motivou, me corrigiu, me ensinou e me inspirou com seu talento e sua paixão, mostrando que o amor é fundamental para executar um bom trabalho, seja ele acadêmico ou não (e nisso eu sempre acreditei e sempre acreditarei). Também quero dizer obrigada aos funcionários do DLO e à bolsa recebida pela Capes. Por dividir angústias e emoções, agradeço à Letícia Mei, parceira de longa data e agora, também, mestre!

Nada, nada do que hoje conquisto seria possível sem meu maior companheiro e amigo, meu marido Dario. Obrigada por ter cuidado tão bem da nossa casa, nossos gatos e nossas refeições (e nisso você se saiu especialmente bem!) ao longo do mestrado. E por ter cuidado tão bem de nós dois. Nenhuma linha seria escrita sem você, sem suas leituras, sem sua ajuda para digitar tudo que manuscrevi, sem seu bom humor. Te amo tanto. Obrigada por fazer esse sonho possível. 
O morrer que lhe vem daquela vida onde teve Seu sentido e onde conheceu amor e dor. Raine Maria Rilke 


\section{Resumo}

O trabalho discute uma faceta ainda pouco explorada da poeta Marina Tsvetáieva: seus textos dramáticos, em especial o ciclo Romantika (1916-1917). Para tanto, apresenta Uma aventura (1917), peça integrante do ciclo mencionado, em tradução não definitiva. Uma tentativa, ainda que distante, de recriar a voz que a poeta achou para si nos palcos da Rússia recém-soviética. Ao buscar localizar a produção para teatro ao lado da obra poética de Tsvetáieva, o presente trabalho comenta todas as peças teatrais escritas por ela, mas se detém especialmente em Uma aventura, na qual busca as motivações para construções dramáticas tão díspares em relação à realidade que Marina Tsvetáieva encontrava na sua cidadenatal. Lança-se mão de um breve comentário sobre a teoria do individualismo e da paródia para elucidar uma possível interpretação de Uma aventura. 


\begin{abstract}
This study discusses an underexplored side of Marina Tsvetáieva's work: her dramatic creations, specially the Romantika (1916-1917) cycle. In order to do so, it presents a non settled translation of Uma aventura (1917), a play from that cycle. It's an intent to recreate the voice that the poet developed for herself on the stages in Russia, during the beginning of the soviet regime. When comparing side by side Tsvetáieva's dramatic and poetic oeuvre, this study offers commentary on all her plays, while focusing specifically on Uma aventura, in which it searches for the reasons that would lead her to create theatrical inventions that were very different to those she would find in her homeland. In order to develop a possible interpretation of Uma aventura, a brief theory of individualism and parody is sketched.
\end{abstract}




\section{SUMÁRIO}

Apresentação 10

\section{Parte I}

Capítulo 1: Marina Tsvetáieva - vida e poética 13

NO TEATRO 22

COM OS CLÁSSICOS 26

ROMANTIKA 33

Capítulo 2: Marina Tsvetáieva - Uma aventura no drama 38

APONTAMENTOS DE ANÁLISE 38

BIOGRAFIA E FICÇÃO 47

SÍMBOLOS, INDIVIDUALISMO E PARÓDIA 51

\section{Parte II}

NOTA À TRADUÇÃO 61

UMA AVENTURA: TRADUÇÃO 62

ПРИКЛЮЧЕНИЕ: TEXTO ORIGINAL 127

Bibliografia 198 


\section{APRESENTAÇÃo}

A ideia deste estudo nasceu ainda no fim da graduação, em 2011, em conversas com a minha orientadora e professora, Dr. ${ }^{a}$ Arlete Cavaliere, quando juntas buscávamos um tema que envolvesse meus interesses: teatro russo no século XX e a representação da voz feminina no mesmo período. Quando a professora, em uma de nossas reuniões, indicou um livro que havia trazido recentemente da Rússia com peças de Tsvetáieva, a poeta já me era familiar.

Meu primeiro contato com a poética da escritora foi em uma aula de língua russa ministrada pela professora Elena Vássina, logo em um dos primeiros meses do curso de russo. Era costume da professora Elena trazer para a sala de aula poemas curtos para os alunos memorizarem e traduzirem para o encontro seguinte. Lembro-me claramente de ter pedido a ela que nos trouxesse na próxima aula algum poema de Tsvetáieva, poeta que conhecia de algumas pesquisas feitas na biblioteca da Universidade por conta própria. Jamais me esquecerei do belíssimo poema que ela trouxe, “Любовь", о primeiro poema russo que decorei. Lembro-me do impacto que senti ao ler em sala este poema e minha tradução. Uma voz emocional que, sem soar piegas, permitia-se falar sobre o amor em sua plenitude. Uma voz que questiona o que dizem do amor: ele não é fogo, não é punhal, é familiar, como nos é a palma de nossa própria mão, é o doce som da voz dos filhos.

Portanto, quando a professora Arlete mostrou o livro com peças de Tsvetáieva, não acreditei que aquilo seria possível: como uma poeta tão lírica em sua essência poderia legar sua voz íntima e pessoal a personagens e cenas que não fossem exatamente de sua vida? No mesmo momento, mesmo antes de ler as peças, sabia que aquela tinha de ser minha primeira pesquisa como pós-graduanda. Se, naquele pequeno poema, Marina já me tocara de forma arrebatadora, imaginei como não seriam os anos de mestrado ao lado dessa figura tão misteriosa e avassaladora.

O teatro de Marina Tsvetáieva é pouco estudado entre os especialistas em literatura russa em todo o mundo. São poucas as obras de crítica que se debruçam sobre essa produção tão rica e interessante e são ainda mais raras as traduções das peças para línguas ocidentais. Saber que estava entrando em um terreno pouco mapeado não me assustou, mas ao contrário, impulsionou a vontade de conhecer o trabalho de Marina por inteiro, em todas as suas manifestações poéticas, uma vez que essas manifestações 
são, em si, o melhor retrato de quem foi Tsvetáieva, como viveu e como entrou para a história.

O projeto nasceu ambicioso, por minha própria culpa: queria traduzir toda a obra dramática da autora. Mas como me orientou a professora Arlete, acabei focando a dissertação para a tradução de Uma aventura, penúltima peça do ciclo dramático Romantika, escrita por Tsvetáieva enquanto a escritora ainda frequentava e participava do teatro-estúdio de Vakhtângov. É a primeira peça em que aparece o personagem Giacomo Casanova, que será parte fundamental do que prentendo discutir aqui. A obra faz parte do mais longo dos dois ciclos dramáticos que Tsvetáieva escreveu ao longo da vida: Romantika engloba seis pequenos dramas escritos enquanto a autora estava envolvida com o terceiro teatro-estúdio, no ano seguinte ao da Revolução, quando já se encontrava em apuros financeiros e sem confiança nas mudanças anunciadas. O outro ciclo dramático, uma trilogia não finalizada, foi escrita posteriormente, já em exílio, e trata de duas personagens da mitologia clássica, sobre a qual discuti no primeiro capítulo.

A tradução de Uma aventura realizou-se ao longo de todo o período do mestrado e é fundamental para exemplificar o que era o teatro que Tsvetáieva acreditava ser possível para si: o teatro que fosse a própria poesia. Por isso, a escolha por acomodar a tradução como última parte da dissertação: Uma aventura é a materialização do que é debatido teoricamente nos dois capítulos que a precedem, assim, é possível ver em prática a produção de Tsvetáieva.

Sobre a estrutura da dissertação: além da tradução e do texto original em russo (parte II), a dissertação é composta de mais dois capítulos (parte I). O primeiro propõe o estudo mais amplo da relação Tsvetáieva-Teatro. Contempla, portanto, a aparição de ícones do teatro em seus primeiros escritos, seus amigos da cena teatral de 19171918, a obra História de Sônetchka, escrita em exílio sobre sua relação com o teatro moscovita e toda a sua obra dramática, que está circunspecta aos ciclos supracitados. Também é aqui que as relações entre teatro e poesia são exploradas.

O segundo capítulo da dissertação tem um viés mais analítico e se prende especialmente à construção de Uma aventura que, como dito, foi escolhida para ser a obra representante do ciclo Romantika para esses estudos. É aqui que são analisados os personagens, o enredo, o tempo e o lugar em que a ação decorre. As chaves que proponho para uma leitura aprofundada de Uma aventura apresentam-se em 
diferentes níveis: relação da peça com a biografia de Casanova (segundo a própria autora, fontr da peça), os elementos simbólicos presentes na obra, análise do mito do sedutor e como o sedutor criado por Tsvetáieva dialoga com o as demais obras de arte que se baseiam no mesmo tema. O viés paródico de Uma aventura é fundamental para que se esclareça a predileção de Marina por um tema tão distante de sua realidade no momento que em que escrevera Romantika.

O maior objetivo que persegui com essa dissertação é justamente este: entender porque, em 1918, Marina Tsvetáieva, diferentemente da maioria de seus colegas artistas, compôs uma obra que parece apartada do mundo russo em que vivia. Segundo a dualidade que se colocava à época, seria uma alienação? Seria algum tipo de protesto? Justamente essas questões foram as maiores motivações teóricas para aprofundar-me num aspecto ainda tão pouco estudado (e até negligenciado) sobre a profícua poeta. Acredito na importância de estudar o teatro de Tsvetáieva não como uma manifestação menor de seu gênio, mas como complemento de sua obra poética, como a procura de uma nova estética e, prioritariamente, como manifestação da mesma voz, dos mesmos ideais, da mesma paixão que sempre foi o que cativou especialistas em Tsvetáieva ao redor do mundo. Espero que esse trabalho seja uma contribuição minimamente relevante para o início de estudos voltados às demais facetas de uma poeta tão criativa e cativante. 


\section{PARTE I}

\section{CAPítulo 1}

\section{MARINA TSVETÁIEVA - VIDA E POÉTICA}

Marina Ivánovna Tsvetáieva nasceu em Moscou, em 9 de outubro de $1892^{1}$, numa família abastada financeira e intelectualmente. Viveu e escreveu durante alguns dos eventos mais turbulentos da história da Rússia: a Primeira Guerra Mundial, a Revolução Russa, a Guerra Civil e a grande fome, vindo a falecer no início da Grande Guerra Patriótica, denominação soviética para o que conhecemos como Segunda Guerra Mundial.

Os pais de Tsvetáeiva, Maria Aleksándrovna Meyn e Ivan Vladímirovitch Tsvetáiev, proporcionaram aos filhos um ambiente repleto de cultura. A mãe de Marina marcou a vida da filha através da música e da poesia, além de ensiná-la a admiração pela natureza. Tsvetáiev, por sua vez, era professor na Universidade de Moscou, filólogo e colecionador de arte. Foi o fundador e diretor do museu de belas artes de Moscou, hoje conhecido como Museu Estatal Púchkin de Belas Artes. A própria Marina comenta em seus diários como o ambiente familiar foi fundamental no seu desenvolvimento como poeta ${ }^{2}$.

Marina lançou seu primeiro livro de poema aos dezoito anos e, no mesmo ano, conheceu Serguei Efron, à época um estudante de Filosofia de dezessete anos. Casaram-se no ano seguinte, em 1912, o ano do nascimento da primeira filha do casal: Ariadna. Eles tiveram mais dois filhos: Irina, que ainda nasceu em Moscou, e Gueórgui (apelidado desde pequeno de Mur), nascido onde hoje reconhecemos a República Tcheca.

Além de ter passado pelas desgraças que marcaram a História mundial, a vida de Tsvetáeiva também passou por inúmeras desgraças pessoais, como a morte por fome de Irina, da segunda filha de Marina e Serguei Efron. O seu destino, como

\footnotetext{
${ }^{1} 26$ de setembro, no antigo calendário juliano.

${ }^{2}$ Cf. Marina Tsvetáieva. Vivendo sob o fogo: confissões, org. Tzevetan Todorov, trad. Aurora Bernadini. São Paulo: Martins Fontes, 2008, p. 80-82.
} 
aponta Todorov na introdução de Vivendo sobre o fogo: confissões, é um dos mais trágicos entre os artistas que sofreram no século XX.

Sua vida e sua obra não podem, em momento algum, ser dissociadas. Escrever foi o que a manteve viva até que as alternativas de sobrevivência em meio a guerra definharam e a poeta perdeu a vontade de escrever e, pior, de amar. O suicídio calou sua voz. Não para sempre, já que sua poesia (bem como toda a sua produção, poética ou não) tornou-se cada vez mais popular, estudada e traduzida ao longo do século XX. Hoje, pode-se afirmar que Marina Tsvetáieva é um dos grandes nomes da poesia de seu século, não somente na Rússia, mas em todo o mundo ${ }^{3}$.

A obra de Tsvetáieva não se encaixa em nenhuma corrente estética exclusiva. Ela não participou de nenhum grupo literário. Como veremos ao longo desta dissertação, apesar de sempre estar atenta aos diferentes movimentos e, em muitos casos, ter elogiado em seus poemas os poetas centrais de sua contemporaneidade (como o poema a Maiakóvski, e os ciclos à Anna Akhmátova, a Blok), manteve-se livre de qualquer amarra estilística que não fosse seu próprio ímpeto de escrever, seja aproximando-se dos simbolistas, seja aproximando-se dos futuristas. Sobre isso, afirma Elisabeth Burgos:

Su lenguaje osado, el jugar a la vez con el ruso moderno, el clásico y el lengaje popular, como lo hizo su admirado Pushkin en su época, la sitúan, aún hoy, más allá de la vanguardía. ${ }^{4}$

\footnotetext{
${ }^{3}$ Podemos fazer tal afirmação diante da vasta produção acadêmica e editorial sobre Tsvetáieva nas últimas décadas. Além disso, é possível apontar importantes artistas que se dedicaram a escrever sobre a poeta. Em especial, podemos citar dois textos: "La galaxia Tsvetáieva" (2000) do aclamado autor espanhol Enrique Vila-Matas para a revista Letrillas (Cf. bibliografia), no qual ele expressa sua emoção diante de poemas de Tsvetáieva traduzidos para o espanhol, bem como suas cartas e diários; outro texto que nos interessa é o artigo "Footnote to a poem" (1981) de Joseph Brodsky, publicado no já clássico compêndio de ensaios Less than one: selected essays (Cf. bibliografia), no qual ele disseca o longo poema "Новогоднеe", escrito por Marina em 1927 e que Brodsky considera um marco não só na poética de Tsvetáieva, mas na história da literatura russa de forma geral.

${ }^{4}$ BURGOS, Elisabeth. “Introducción”. In Cartas a las amazonas y otros escritos franceses, p. 19, apud. ALMEIDA, Paula Costa Vaz de. O 'Meu Púchkin' de Marina Tsvetáieva: tradução e apresentação. Dissertação de mestrado, FFLCH - USP, 2008.
} 
A insubordinação estilística e também política tornou-se marca da poética libertária da autora. Justamente por essa liberdade, Tsvetáeiva não teve receio algum de flertar com poetas que eram temporariamente mal vistos (ou estavam em “desuso”) no início do século XX (como Derjávin), de entregar-se ao estudo de Shakespeare, Rostand e Rilke enquanto o programa da época discutia Marinetti, ou mesmo declarar seu mais profundo amor por Púchkin, tantas e tantas vezes ${ }^{5}$. Pode-se dizer que a única diretriz que fora frequente na obra de Tsvetáieva era seu compromisso consigo mesma, com o amor, com seus alumbramentos de menina e suas paixões tão constantes e ardentes, mesmo que quase nunca concretizadas (seus "idílios cerebrais") ${ }^{6}$ na idade adulta.

Mesmo jamais se filiando a correntes artísticas ou a ideologias políticas, mantendo sempre seu pensamento e sua arte individualizadas, Tsvetáieva sinaliza em toda a sua poética referências claras às culturas clássicas, tanto russa quanto europeia, de diferentes maneiras e de diferentes épocas. Ela produz, assim, uma linha de criação lírica independente:

\begin{abstract}
Difícil falar-se em influências ou em coincidências. Em toda a sua obra em prosa ou em verso há diálogos e "transmutações" com poetas e escritores de todas as épocas e de todas as partes. Entretanto, no domínio universal da poesia, em sua essência e sua expressão, ela é Marina Tsvetáieva, única e inconfundível. ${ }^{7}$
\end{abstract}

Desde muito jovem, Marina já revela sinais de sua personalidade que ficarão sempre notáveis em sua obra. Nos seus escritos em prosa, ela relembra:

Minhas primeiras línguas: o alemão e o russo; a partir dos sete
anos, o francês [...]. Minha ocupação favorita, a partir dos
quatro: a leitura; a partir dos cinco: escrever. Tudo o que eu
amei, amei antes dos sete, depois, nada mais. Aos 47 anos posso

\footnotetext{
5 Vale lembrar o carinhoso texto memorialístico "Meu Púchkin", escrito por Tsvetáieva já no exílio, no qual a autora recorda seu primeiro contato com o poeta. Cf. Paula Vaz da Costa, op., cit.

6 "Essas paixões, com muita frequência de curta duração, raramente chegam a ser relações físicas, mas dão lugar ao que ela própria chama de 'idílios cerebrais' e inspiram ciclos de poemas: os versos dizem inicialmente seu amor, em seguida sua inquietude, por fim sua decepção" in TODOROV, T. A beleza salvará o mundo, trad. Caio Meira. Rio de Janeiro: Difel, 2011, p. 197.

${ }^{7}$ BERNARDINI, A. Indícios flutuantes em Marina Tzvetáieva, Tese de livre-docência, FFLCH USP, 1976, p. 13-14.
} 
dizer que tudo o que iria conhecer, conheci antes dos sete, depois só tomei consciência $[\ldots . .]^{8}$

Podemos questionar, mesmo diante da declaração supracitada, se suas admirações literárias ficaram mesmo só reservadas ao que ela conheceu na infância. Segundo Aurora Bernadini, "suas descobertas e afinidades variam de acordo com seu amadurecimento pessoal", , como é esperado que ocorra. Os alvos de sua mais jovem admiração são Napoleão I, Napoleão II, Edmound Rostand, Púchkin. Depois de tornar-se poeta publicada, o meio poético leva-a logo a conhecer e amar outros autores: Aleksandr Blok e Reine Maria Rilke são alguns deles.

Porém, Bernadini nos informa em Indícios flutuantes em Marina Tsvetáieva, que os primeiros dois livros de Tsvetáieva possuem uma forte dedicação aos amores da infância da poeta ${ }^{10}$. Álbum da tarde (1910), sua primeira coletânea, foi a porta de entrada de Marina no meio literário moscovita, onde foi bem recebida pela crítica e por demais poetas e artistas. Sua segunda coletânea, Lanterna mágica, foi publicada em 1912, ano do casamento da poeta com Serguei Efron. Tanto os poemas de Álbum da tarde como de Lanterna mágica possuem a mesma ambiência, que retoma o pequeno trecho da autobiografia de Marina, supracitada: "tudo que amei, amei antes dos sete". Esses primeiros livros pertencem ao que Bernadini considera a primeira fase da produção poética de Tsvetáieva. Nela, identificamos a presença da infância, das descobertas que fizera quando pequena, os encantos dos primeiros versos, dos primeiros mestres. E, também, a primeira assimilação da poesia de sua época em alguns vestígios simbolistas.

Se a obra de Marina Tsvetáieva tivesse ficado resumida às suas primeiras coletâneas (Álbum da tarde, Lanterna mágica e De dois livros ${ }^{11}$ ) escritas até 1913 , ou tivesse continuado nesse veio lírico e temático, ocuparia, dentro da História da Literatura Russa, um lugar muito especial como um dos poetas menores da época pós-simbolista [...]. ${ }^{12}$

\footnotetext{
${ }^{8}$ TSVETÁIEVA, M. Vivendo sobre o fogo: confissões, op. cit., p. 81.

${ }^{9}$ BERNARDINI, A. op. cit., p. 11.

${ }^{10}$ Id. ibid., p. 11.

${ }^{11}$ De dois livros é uma coletânea feita com poemas selecionados de Lanterna mágica e Álbum da tarde.

${ }^{12}$ BERNARDINI, A. op. cit., p. 27.
} 
O tom dos poemas de Tsvetáieva em sua primeira fase é intenso e mostra características que permaneceram na obra da poeta, tanto em sua poesia como em sua prosa. Sobre seus dois primeiros livros, escreveu S. Karlinsky:

\begin{abstract}
The earliest poems that found their way into her first two collections date from the winter of 1907-08. Their themes and ideas may be adolescent and occasionally naive, but technically they are the work of a master. [...] Like all her lyric poetry, those firts two books are a diary of her life, encounters, interests and current reading, all of it transfigured by the alchemy of poetry into a higher reality. ${ }^{13}$
\end{abstract}

"O amor desesperado por seu mundo russo da infância é o primeiro traço distintivo de toda a sua obra"14, afirma Bernadini. Nesse retorno à infância é fundamental perceber que ficará como traço da obra de Tsvetáieva a busca por um passado, que pode tanto ser o seu próprio, ou de sua vida familiar no bulevar Tvier, ou até mesmo uma história que se passou em uma cidade na Itália, séculos atrás.

Podemos interpretar esse recurso artístico tanto como um sentimento de inadequação a seu tempo, bem como um escapismo consciente de sua realidade. A produção teatral de Tsvetáieva, principalmente seu ciclo de peças Romantika, dialoga com essa busca ao passado, apesar do ciclo ter sido escrito somente em 1918. Trataremos mais adiante com maior minúcia sobre a produção dramática de Tsvetáieva.

O próximo livro de Marina, Versos juvenis (poemas escritos entre 1913 e 1915), aponta para uma nova fase em seu percurso poético. A síntese irá acompanhá-la nessa frutífera fase. Vale ressaltar a variação temática em relação ao que foi produzido anteriormente: o amor deixa de ser a grande referência no plano dos sentimentos, e a dor, a perda, a morte e a maternidade começam a apontar para um amadurecimento que é tanto temático quanto formal.

\footnotetext{
13 KARLINSKY, S. Marina Tsvetaeva: the woman, her world and her poetry. Cambrigde: University of Cambridge Press, 1985, p. 38.

${ }^{14}$ BERNARDINI, A. op. cit., p. 14.
} 
É neste momento que dois grandes nomes aparecem como referência constante na poesia de Tsvetáieva: Púchkin e Byron ${ }^{15}$. Napoleão Bonaparte, onipresente na primeira fase de Marina, começa a abrir espaço, aos poucos, para outros nomes.

Em 1916, Marina Tsvetáieva termina Verstas I, seu primeiro livro composto quase que integralmente de poemas e ciclos dedicados a grandes inspirações para sua arte. A obra será publicada somente em 1922, em Moscou. Além de Púchkin, neste livro Tsvetáieva homenageia Akhmátova e Blok com ciclos de poemas. O principal método de composição de Marina, tanto em poemas dedicados a Púchkin mas também, e principalmente, nos poemas dedicados a seus contemporâneos, é a emulação. Como forma de exercício estilístico e como forma de simbiose, de união ao ser louvado, Marina consegue transmutar sua voz à voz daquele que homenageia. Dessa forma, seus poemas dedicados a poetas que admira possuem o tom (elemento poético fundamental, uma essência do poético transfigurado em som, ritmo e tema) característico dos poetas homenageados. "Sua maestria poética chegou a tal ponto", diz Aurora Bernadini, "que, nos ciclos de poemas que ela dedica a Blok e Akhmátova, seus ídolos dessa fase, reproduz, de maneira surpreendente, a voz desses poetas". ${ }^{16}$ Assim, Marina vai construindo a sua própria $\operatorname{voz}^{17}$.

\footnotetext{
${ }^{15}$ Sobre a presença de Byron na sua poesia mais juvenil, Tsvetáieva escreveu: "Estava preparando uma coletânea - de 1913 a 1915 - os versos antigos ressurgiam e chamavam de volta à vida, eu os corrigia, os ordenava, completamente encantada pelos meus vinte anos e por todos aqueles a quem eu amava então: a mim própria - Ália - Seriója - Ássia - Piotr Efron - Sonia Parnok - minha jovem avó - os generais do ano de 1812 - Byron - e - não dá para enumerar todos!” in TSVETÁIEVA, M. Vivendo sob o fogo: confissões, op. cit., p. 173.

${ }^{16}$ BERNARDINI, A. op. cit., p. 28. Ainda podemos esmiuçar essa questão observando os ciclos de poemas mais relevantes que Tsvetáieva criou para seus contemporâneos. O primeiro, "Poemas a Blok” (“Стихи к Блоку”), é composto por dezesseis poemas escritos entre 1916 e 1921, ano da morte do poeta; o segundo é o ciclo "À Akhmátova” (“Ахматовой”), composto de treze poemas escritos em 1916. Em "Poemas a Blok", Tsvetáieva usa imagens, para descrever Blok, que primeiro apareceram nas obras do próprio poeta, tais quais o poeta-mártir e o anjo caído. Ela concebe a poética de Blok, emulando o homenageado, como uma não autoria que transcende os corpos e os gêneros e sublima o erotismo que há nesta admiração. Temos um exemplo dessa emulação já no primeiro poema do ciclo, "Na mão - um pássaro que cala" [trad. Aurora F. Bernadini]. É um poema elaborado em cima das possibilidades sonoras da palavra "Blok", no qual Tsvetáeiva aponta para temas da poética de Blok em associação à sonoridade do nome do poeta. No ciclo dedicado à Anna Akhmátova, Tsvetáieva apresenta a poeta como um ser humano superior
} 
Marina e Serguei têm sua primeira filha, Ariadna (Ália) em 1912; Irina, a segunda filha do casal, nasce em 1917. Em 1914, Efron une-se ao Exército Branco. Mesmo diante da eminente Revolução, permanecem unidos em Moscou. Em 1916, o casal começa a frequentar o Teatro de Câmara de Aleksandr Taírov onde atuam ao lado de Vera, irmã de Serguei. Esse foi o primeiro contato de Tsvetáieva com um grupo de teatro. Ela voltará ao ambiente cênico dois anos mais tarde.

A Revolução desestabiliza a vida da jovem família moscovita. Marina e Serguei viajam para a Crimeia sem as filhas e somente Marina volta de lá. Serguei segue outros rumos com o Exército Branco. Tsvetáieva e as filhas permanecem na Rússia somente até 1922. Antes de partirem, a poeta compõe mais duas obras: Acampamento de cisnes, somente publicado postumamente em Munique, 1957, tem como forte característica a reflexão sobre a Revolução e a questão socialista, é claro o apoio ao Exército Branco; a outra obra é Verstas II, uma coletânea de poemas escapistas escritos entre 1917 e 1921, mostra a "voluntária alienação" de Tsvetáieva diante dos debates de sua época, e diante do sofrimento e da privação que são impostos a ela pelas calamitosas circunstâncias do período pósrevolucionário. De todo esse sofrimento, o mais forte é a morte de Irina, sua filha mais nova até então, num abrigo para crianças, em 1922. Sobre a fuga poética de Tsvetáieva, escreve Bernadini:

aos demais, como um símbolo de um poder poético irrefreável, atrativo, mas ameaçador. Aqui, Marina, além da emulação da voz da poeta homenageada reapresenta temas caros à Akhmátova, como a busca pela Musa. Marina, porém, encontra a Musa na presença da própria Akhmátova: “Ó musa das lágrimas, a mais bela das musas!/ Ó tu, espírito indomável da noite mais branca!/ Sobre a Rússia desatas uma negra tormenta/ e os gritos trespassam-nos como flechas.// E recuamos, esmagados, e com um oh! abafado,/ mil vezes repetido, prestamos-te homenagem. Anna/ Akhmátova! O teu nome é um suspiro interminável,/ Que nos inomináveis abismos se despenha” [trad. António Mega Ferreira]. Em outro poema do ciclo, Tsvetáieva reconhece Akhmátova como a grande poeta russa, declarando que Anna é a própria Rússia. (cf., sobre poemas a Blok e à Akhmátova, Alyssa W. Dinega, A Russian Psyche: The Poetic Mind of Marina Tsvetaeva, na bibliografia).

${ }^{17}$ Falaremos mais profundamente sobre como Tsvetáeiva formula sua voz, sobre a questão da emulação como intertextualidade e sobre simbiose entre Tsvetáieva e os alvos de sua admiração poética ao analisarmos Uma aventura, no próximo capítulo da dissertação. 
Verstas II reúne os poemas da fuga para o passado e da voluntária alienação de um presente insuportável. As principais referências literárias se prendem a esta época: Manon Lescaut, Cagliostro, Casanova, Dickens.

Representam a culminação do romantismo tsvetaieviano. Sua dicção elegante deliberadamente refinada surpreende, se comparada à dos ciclos anteriores.

As fontes de inspiração são o mundo do teatro (de acordo com as informações biográficas, muito significativo nesta sua fase. A ela se prendem os ciclos "Versos a Sonetchka", "Irmãos" e "O comediante" $[\ldots]) .{ }^{18}$

Para o estudo que faremos a respeito das primeiras peças teatrais escritas por Tsvetáieva é importante que tenhamos em mente o universo presente em Verstas $I I$, já que as peças são escritas durante o processo de elaboração da coletânea de poemas. A vida de Marina é marca registrada em suas criações, portanto, as obras escritas numa mesma época revelam as várias faces da artista naqueles anos. A fase com viés mais romântico, todavia, fica reduzida a Verstas II e Romantika. A obra seguinte de Tsvetáieva, Ofício (com poemas escritos entre abril de 1921 e abril de 1922, lançada em Praga, em 1923), afasta-se da temática idílica e se aproxima das tendências poéticas da vanguarda literária: o cubofuturismo de Maiakóvski e Khlébnikov pode ser percebido através de alguns procedimentos poéticos. Bernadini destaca os seguintes padrões em sua criação: “as palavras são 'descarnadas', os versos são encurtados e o procedimento de paronomásia, com criação de termos a partir de uma raiz comum, se torna o traço característico de seu fazer poético" ${ }^{19}$.

Depois da Rússia, sua última coletânea de poemas curtos, foi escrita inteiramente no exílio, entre 1922 e 1925. Serguei Efron já havia deixado a Rússia quando Tsvetáieva enfrentou com as filhas as privações e a fome do período pós revolucionário, bem como a trágica morte de Irina. Em 1921, finalmente Marina recebeu a notícia de que Efron estava vivo e a esperava em Praga. Todavia, emigrar não foi uma decisão fácil para a poeta, que temia a recepção no hostil mundo ocidental. Diante das circunstâncias que vivia na recém-estabelecida União Soviética, que além de pobreza envolviam riscos de perseguição por parte da polícia comunista, Tsvetáieva decide partir com Ariadna para encontrar o marido.

\footnotetext{
${ }^{18}$ BERNARDINI, A. op., cit., p. 30.

19 BERNARDINI, A. "Prefácio" in M. Tsvetáeiva. Indícios flutuantes (poemas). São Paulo: Martins Fontes, 2006, p. L.
} 
A família viveu em Berlim, Praga e Paris. Mas em nenhuma dessas cidades Tsvetáieva conseguiu ser plenamente aceita como poeta, nem pelos russos emigrados como ela, nem pelos europeus em geral. A saudade da terra natal foi pungente durante todo o período do exílio.

A coletânea de poemas que marca fortemente esse período é justamente Depois da Rússia. Segundo Karlinsky, temos neste conjunto poético uma síntese do romantismo de Verstas II, o tom coloquial presente em Verstas I e o estilo marcado da poesia do século XX presente em Ofício $^{20}$.

Após Depois da Rússia, Marina diminuiu sua dedicação aos poemas curtos, dando espaço a outras produções também muito interessantes, como sua prosa crítica e memorialística, e também o teatro. Em 1927, dá inicio a uma trilogia teatral ligada aos mitos clássicos intitulada Teseu que seria composta das seguintes obras: "Ariadna", "Fedra" e "Elena". Todavia, a terceira peça nunca foi escrita. Falaremos mais sobre Teseu no próximo tópico deste capítulo.

Em 1939, Tsvetáieva voltou à Rússia com seu filho Mur. Serguei Efron e Ália já os haviam precedido e estavam determinados a se engajarem na campanha soviética durante a Segunda Guerra, uma vez que Serguei havia abandonado a luta contra os soviéticos enquanto estava fora da Rússia. Quando a guerra de fato eclodiu e Marina deixou de ter notícias de Efron e Ália (ele sumira nos cárceres soviéticos e ela fora enviada a um gulag, por onde ficou por dezesseis anos, afinal, claramente não eram confiáveis para o governo stalinista, uma vez que já haviam se envolvido com os Brancos e morado muitos anos no exterior). Durante a ocupação germânica no território soviético uma evacuação dos centros leva Tsvetáieva e o filho à cidade de Elabuga, na então República Tártara. Sem recursos, sem sua família (Mur certamente seria convocado ao front), sem condições de escrever, Marina Tsvetáieva suicida-se em agosto de 1941, deixando uma obra inigualável e até hoje permanece entre os grandes nomes da poesia do século XX.

\footnotetext{
${ }^{20}$ S. Karlinsky, Marina Cvetaeva - her life and art, apud. A. Bernadini Indícios Flutuantes em Marina Tzvetaieva, op., cit., p. 31.
} 


\section{No teatro}

Uma vez que temos em mente o percurso biográfico e poético de Marina Tsvetáieva, podemos nos debruçar minuciosamente nos momentos em que as artes dramáticas estiveram entre as atividades da poeta.

Em 1918, Marina Tsvetáieva morava somente com as duas filhas em Moscou e com elas enfrentava os anos econômica e politicamente complicados do comunismo de guerra. O marido, Serguei Efron, tinha ficado na Crimeia, onde haviam morado juntos por um breve período, sem as meninas. Marina voltou para encontrá-las e Serguei, sozinho, juntou-se ao Exército Branco. Ela só voltaria a encontrá-lo em 1922, no exílio.

A poeta não se declarou em nenhum momento partidária deste ou aquele ideal político. Não viu vantagens na Revolução Socialista: a pobreza e a fome em Moscou foram provas fidedignas para ela da ineficácia do projeto comunista. Mesmo assim, manteve amizades com artistas declaradamente comunistas e preferiu sempre se referir a si mesma como apolítica, desinteressada por estas preocupações terrenas. Ela escreveu em seu diário, em 1919: “Todo meu credo político é contido numa única palavra: frondeuse [crítica] e, para maior precisão, posso acrescentar outra: essentiellement [essencialmente]"21.

Marina já era uma poeta reconhecida e dominava completamente seu oficio nessa época, como vimos anteriormente. Seus dois livros de coletâneas, Álbum da tarde e Lanterna mágica, foram bem aceitos no meio literário ${ }^{22}$ e sua poética fora reconhecida pelo vigor pessoal que carrega e pelo domínio da arte. Porém, seus recursos financeiros, até a Revolução tão fartos, tornaram-se escassos e Marina precisou procurar meios de sobrevivência, desde trabalhos para os quais não se sentia apta e, até mesmo, pediu ajuda de amigos.

Foi nesse momento que Tsvetáieva conhecera o teatro-estúdio ${ }^{23}$ de Vakhtângov e abrira portas para diferentes experiências em sua vida. No grupo do estúdio, fez

\footnotetext{
${ }^{21}$ M. Tsvetáeiva, Vivendo sobre o fogo: confissões, op., cit.

${ }^{22}$ Cf. S. Karlinsky, Marina Tsveaeva: the woman, her wolrd, her poetry, op., cit.

${ }^{23}$ Sobre os teatros-estúdios, Jacó Guinsburg escreveu: “A procura por uma espiritualidade mais profunda, inclusive no palco, começava a fazer-se em 'estúdios' que, evitando a pesada carga de organização teatral vigente [do Teatro de Arte de Moscou, principalmente], lançavam-se pelas
} 
amizades que levará vida afora, mesmo que somente na memória; para citar alguns: Pável Antokolski, ${ }^{24}$ que se tornará um renomado poeta do período soviético, e Sonia Holliday, ${ }^{25}$ atriz no teatro-estúdio ${ }^{26}$. As novas experiências mencionadas manifestaram-se tanto em sua obra como em sua vivência: o grupo de amigos do teatro mantinha relações românticas tanto de natureza hétero como também homoafetivas e Marina acabou se apaixonando por Sonia Holliday. O envolvimento com os ensaios da trupe levou a poeta a escrever peças, pela primeira vez.

O período de envolvimento com o teatro fora tão marcante para Tsvetáieva que anos mais tarde, já no exílio, escreveu um livro em que rememora a época vivida no teatro-estúdio e comenta algumas das peças que produziu à época. História de Sonétchka (Повесть о Сонечке, 1937), como o título indica, é dedicado à atriz que tanto marcara a vida de Marina. Na obra, Tsvetáieva conta como conhecera o teatro de Vakhtângov (através do poeta Pavlik A. e de seu amigo Iuri Z.), como escrevera suas peças, e como foi a leitura da primeira delas, Tempestade de neve, para os atores do teatro e para o próprio Vakhtângov. Tsvetáieva confessa em História de Sónietchka que se empenhou para dar à Sonia as melhores personagens que pudesse escrever (incluindo "Menina", de Uma aventura). Somente ela seria a encarnação das mulheres que Tsvetáieva poderia imaginar, pois sabia o que é o verdadeiro teatro do amor, como afirma Marina no texto memorialístico. As peças foram escritas com a intenção de serem montadas pela trupe, o que nunca aconteceu. Marina descreve seu relacionamento com Sonia em História de Sónetchka como uma paixão platônica que se transforma em fortíssima amizade, negando qualquer envolvimento físico. $\mathrm{O}$ carinho por

sendas de experimentação cênica”. Cf.: J. Guinsburg. Stanislávski, Meyerhold e cia. São Paulo: Perspectiva, 2008, p. 22.

${ }^{24}$ Pável Grigorievitch Antokolski nasceu em São Petersburgo, em 1896. Foi um importante poeta soviético e veio a falecer em Moscou, em 1978. Para mais informações sobre ele, cf.: $<$ http://www.antokolsky.com/> (site oficial mantido pela família de Antokolski).

25 Não encontramos muitas informações sobre Sonia Holiday, somente o que nos disse dela Tsvetáieva. Nos seus diários reproduzidos em Vivendo sobre o fogo, Sónetchka aparece em anotações e cartas em diferentes épocas da vida da poeta. A última menção a ela é de 1940.

${ }^{26}$ A ambos Tsvetáieva escreveu poemas em 1919: "P. Antokolski” (П. Антокольскому) е о ciclo “Versos à Sonetchka” (Стихи к Сонечке). 
Sónetchka e os sofrimentos das privações em Moscou àquela época fazem Tsvetáieva rever sua postura sobre as relações afetivas e também rever o que pensa sobre si mesma. Descobre que para sobreviver à margem da história, se é que isso é possível, deve se reinventar: "serei fogo"27.

Além da breve experiência no teatro de Taírov de 1916, não há registros que comprovem qualquer alumbramento de Tsvetáieva pelo teatro russo antes dessa data. Podemos verificar, através de seus diários, que desde sempre ela leu e amou Edmond Rostand, chegando a traduzir sua obra L'Aiglon ${ }^{28}$. Também foi encantada por Sarah Bernhardt. Mas é significativo pensar que ambos são ícones do teatro francês. O teatro russo, claro, não era completamente desconhecido de Tsvetáieva, mas sempre fora o teatro ocidental que lhe chamou atenção.

Todavia, o caminho da composição do texto dramático não havia sido explorado pela poeta até então, uma vez que não há notícias de que tenha escrito alguma peça teatral antes deste momento. Mas, segundo ela mesma, tudo aconteceu naturalmente: "Je me suis mise à écrire des pieces - il était inévitable que cela se produise - ma voix était devenue trop forte pour les vers, mon souffle trop puissant pour la flute". ${ }^{29}$

Entre o fim de 1918 e o começo de 1919, durante um impulso criativo, como aponta Hélene Henry ${ }^{30}$, Tsvetáieva escreveu seis peças não muito longas: Valete de copas (Червонный Валет), A tempestade de neve (Mетель), Fortuna (Фортуна), O anjo de реdra (Каменньй Ангел), Uта aventura (Приключение), e sua peça mais bem acabada, Fênix (Феникс). Essas duas últimas peças retratam acontecimentos da vida de Giacomo Casanova e o último ato de Fênix foi publicado também como $O$ fim de Casanova (Конеи, Казанобы). São seis peças breves que trazem um clima de sonho, ambientadas em aventuras amparadas na história e no imaginário europeu. O tema que mais se destaca é o reencontro amoroso.

\footnotetext{
${ }^{27}$ Cf.: Marina Tsvetáieva, Vivendo sob o fogo: confissõesi, op., cit., p. 138-139.

${ }^{28}$ L'Aigon é uma peça em seis atos escrita por Edmond Rostand baseada na vida de Napoleão II. A estreia foi em 1900 com Sarah Bernhardt no papel-título.

${ }^{29}$ Hélene Henry. "Préface" in Marina Tsvetáieva, Romantika, trad. Hélene Henry. Paris: Gallimard, 1998, p. 10.

${ }^{30}$ Id., ibid., p. 10.
} 
As obras formam um conjunto, um ciclo coeso que mais tarde, nos anos de 1920, Marina chamará de Romantika (Романтика). O ciclo reinterpreta livremente o destino de personagens históricos ligados à sedução: Duque de Lauzan, Princípe de Ligne e Giacomo Casanova em dois momentos: jovem e apaixonado em Uma aventura, e maduro e risível em Fênix. As personagens femininas, no entanto, foram elaboradas, como dito, para a interpretação de Sonia Holliday. Falaremos detalhadamente das peças que compõem Romantika mais adiante neste capítulo.

A dramaturgia caminha de mãos dadas com a poesia, já que as peças que Marina escreveu são indissociáveis dos ciclos de poemas em que trabalhava na mesma época, como "Versos à Sonia", "O comediante" e "O aluno". A relação dialógica entre poesia e dramaturgia é construída pela primeira vez na obra de Tsvetáieva e a poeta anotou em seus cadernos que o poema tornara-se momentaneamente insuficiente para sua voz. Todavia, contradirá esse pensamento, na década de 20, alegando que o teatro fere a poesia, pois se alia ao que há de menos poético: a realidade, o visível. Em História de Sónetchka, Tsvetáieva afirma: "não nos esqueçamos que estamos no coração da falsidade: o teatro" ${ }^{31}$. Chega até mesmo a proibir que chamem Fênix de peça, alegando que o texto é simplesmente o amor, uma declaração de amor a Casanova ${ }^{32}$.

Só o poema é capaz de realizar-se sozinho em sua totalidade, sem se apoiar nos aparatos cênicos, base do "fenômeno teatral" essência para ter acesso a essa experiência espiritual que é a poesia. Marina nos apresenta uma dramaturgia que assume o direito de posicionar-se fora do teatro, tal como acontecimento cênico.

Romantika, é interessante notar, não foi a única incursão de Marina Tsvetáieva pelo texto dramático. Mesmo tendo abandonado temporariamente o teatro como veículo de sua arte após a experiência com a trupe de Vakhtângov, a poeta voltou

\footnotetext{
${ }^{31}$ ЦВЕТАЕВА, М. Повесть о Цонечке. Москва: Азбука Классика, 2010, p. 82.

${ }^{32}$ Marina escreveu, na introdução tardia (1921) que fez a "O fim de Casanova” (ato final de Fênix que foi publicado indepente): Это не пьеса, это поэма, - просто любовь: тысяча первое объяснение в любви Казанове.

${ }^{33}$ Expressão consagrada por Anatol Roselfend na obra Texto/Contexto I. São Paulo: Perspectiva, 1996.
} 
a visitar o texto dramático bem mais tarde, no exílio, ao buscar compor uma trilogia nos moldes e com os temas das tragédias mitológicas.

\section{Com os clássicos}

O apreço de Tsvetáieva pela mitologia clássica esteve presente em toda a sua produção poética, porém intensificou-se nas últimas coletâneas Ofício e Depois da Rússia. Nesta última, várias seções são dedicadas a personagens mitológicos, entre elas encontramos um ciclo "Fedra" e um "Ariadna", ambos compostos em 1923. Nos poemas destes ciclos, são as próprias Fedra e Ariadna que assumem o papel do eu-lírico e que versam sobre suas dores e suas paixões. Ainda em 1923, Marina, não por acaso, começa a trabalhar numa trilogia dramática, que se chamaria Teseu, cujas personagens-títulos de cada drama seriam exatamente Fedra, Ariadna e Elena. Como nos apontam Zara Torlona e Maria Fox, a escolha pela mitologia nas coletâneas poéticas e depois nas peças não são feitas ao acaso, mas fazem parte de um projeto poético de Tsvetáieva: trazer a visão do mito de uma forma diferente do que já foi feito por seus antecessores russos, isto é, não "modernizando" as relações e as personagens presentes nas histórias e não se preocupando em manter sua reinterpretação da história fiel àquelas aceitas pelos estudiosos do tema, mas preferindo tomar como fonte as releituras germânicas para as histórias clássicas, como as feitas pelo romantismo alemão: Heine, Novalis e Goethe.$^{34}$ No texto ensaístico Sobre a Alemanha (О Германии) escrito em 1919, Tsvetáieva declara (trad. de Torlone e Fox):

\footnotetext{
I might be saying something bizarre, but for me Germany is Greece continued, ancient, and youthful. The Germans are the heirs. And not knowing Greek, I will not accept from anybody's hands, from anybody's lips but the German that nectar, that ambrosia. $^{35}$
}

\footnotetext{
34 "The characters taken from classical mythology are chosen not at random but in connection with the central preoccupations of Tsvetaeiva's poetic system" apontam as autoras do prefácio "Soul and passion" e tradutoras de "Fedra" e "Ariadna" para o inglês. Cf.: Zara M. Torlone, Maria S. Fox, "Soul and passion" in Soul and passion: Marina Tsvetaeva's Classical Plays: Ariadna \& Phaedra, trad. Z. M. Torlone e M. S. Fox. Ohio: Staroe Vino, 2012.

${ }^{35}$ Id., ibid., p. X.
} 
A trilogia Teseu começou a ser composta pela peça "Ariadna" (1927) e em seguida "Fedra" (1928), porém, nunca foi concluída: Tsvetáieva não escreveu "Elena". O viés temático que a poeta buscou aprofundar nessas peças é de fundamental importância para toda a sua estética (e também para a sua ética pessoal, já que, como apontamos, vida e a obra da poeta são sempre interligadas): a paixão romântica verdadeira, mesmo que fatal e fadada ao fracasso. A predileção de Tsvetáieva por amantes inacessíveis ou, por vezes, não merecedores do sentimento amoroso é evidenciada nos sentimentos frustrados presentes nas peças clássicas, como a paixão de Teseu por Ariadna, depois a paixão da abandonada Ariadna por Teseu e a paixão quase incestuosa de Fedra por Hipolito. Diante disso, podemos concluir que Tsvetáieva não escolheu um caminho muito diferente de seus antecessores, pelo menos no que diz respeito à poesia latina, que considerava os mitos ligados às mulheres de Creta especialmente atrativos porque neles a paixão feminina era vocalizada, muitas vezes através da própria mulher ${ }^{36}$.

\section{Ariadna}

“Ariadna" foi pensada como a primeira peça da trilogia Teseu. É composta por cinco atos, sem divisão de cenas. A peça passa pela derrota do Minotauro por Teseu, mostrando desde a decisão voluntária do herói de ir à Creta derrotar a criatura no labirinto, até seu retorno a Atenas. Ariadna é figura fundamental na trajetória de Teseu, sua ajuda foi o que fez com que ele pudesse matar o Minotauro e sair do labirinto. A princesa de Creta, todavia, pedira a Teseu que após sua vitória prometesse levá-la embora de Creta com ele, promessa que o herói só cumpriu parcialmente.

Os demais personagens da peça são os reis Egeu (de Atenas) e Minos (de Creta), os deuses Poseidon e Baco, um padre, um oráculo, um mensageiro, um aguadeiro e os coros de moças, de jovens, de cidadãos e o povo. Os personagens secundários (mensageiro, estrangeiro, aguadeiro e o povo) e os coros estão presentes na abertura da peça e debatem o sofrimento do povo ateniense que se

\footnotetext{
36 Para entender melhor a questão feminina na poesia latina, indicamos a leitura de Rebecca Armstrong, Cretan Woman: Pasiphae, Ariadna, and Phaedra in Latin Poetry. Oxford: Oxford University Press, 2006
} 
repete toda vez que um tributo deve ser enviado a Minos e seu Minotauro. E são essas vozes que incitam a vontade de Teseu de vencer o desafio cretense.

O Teseu construído por Marina Tsvetáieva é irracional, busca a glória antes de tudo. E a busca frenética por essa glorificação muitas vezes faz com que ele tome atitudes equivocadas. Já a Ariadna que Marina nos apresenta é mais complexa do que costuma ser em demais representações, como a de Gustav Schwab ${ }^{37}$. Mesmo pressentindo que Teseu não fosse a opção mais segura para ela, principalmente quanto a relacionamento amoroso, Ariadna navega com o herói, sabendo tudo o que deixa para trás como filha do rei de Creta. Mesmo com esse ímpeto desbravador, a personagem cumpre o papel de mulher recatada que se espera (bem mais do que faz sua irmã Fedra, como veremos), e as decisões mais importantes do enredo da peça se passam longe de Ariadna, mesmo quando ela é o objeto do debate.

Ariadna não chega a ser uma personagem heroica clássica, mas cumpre perfeitamente o papel que a poeta-dramaturga pretendia para ela: "Not yet fully developed into a tragic heroine (as Phaedra is) she [Ariadna] nonetheless reflects Tsvetáieva's main preoccupation in the trilogy: unhappy love" ${ }^{\text {38 }}$. O que mais aproxima "Ariadna" de um texto nos moldes clássicos, portanto, não é a personagem título, mas a discussão que se dá entre Teseu e Baco, como veremos.

Sabe-se do mito que Ariadna é abandonada por Teseu durante a viagem, na ilha de Naxos enquanto dormia. Todavia, a leitura que Tsvetáieva faz desse abandono distancia bastante a composição da poeta das composições canônicas, como a de Schwab, e é, segundo Torlone e Fox, essencial para a modernização do mito desejada por Tsvetáieva. Ainda segundo as estudiosas ${ }^{39}$, o texto de Schwab também não segue a vertente mais aceita do mito e conta que Baco aparece em sonho a Teseu, o assusta e o ameaça, obrigando o herói a abandonar Ariadna em seu benefício. Nessa versão, o medo é a razão principal que faz Teseu abandonar a sua amada, o que mostra uma falha no aspecto heroico do personagem. Tsvetáieva

\footnotetext{
${ }^{37}$ Gustav Schwab (1792-1850) é autor do livro Sagen des klassischen Altertums, obra de referência que reconta os mitos clássicos e que é amplamente lida e estudada na Alemanha até hoje. Segundo a crítica, Tsvetáieva absorveu muito de seus conhecimentos sobre mitologia através do trabalho de Schwab (Z. Torlone, M. Fox, op. cit., p. X [nota de rodapé]).

${ }^{38}$ Z. Torlone, M. Fox, op. cit., p. XIV

${ }^{39}$ Id., ibid., p. XIV.
} 
subverte completamente essa passagem em sua peça: Teseu e Baco entram em um embate verbal enquanto Ariadna dorme. É esse embate que, ainda segundo as estudiosas americanas, faz com que a peça de Tsvetáieva aproxime-se da tragédia grega: “(...) the agon (or sharp conflict expressed in debate) between Bacchus and Theseus that recalls ancient tragedy most strikingly and forms the culmination of the play"40. O jovem herói, mesmo pressionado por Baco, não quer entregar sua amada, muito menos abandoná-la, ao contrário, decide lutar para levá-la consigo para Atenas. Não obstante, ao perceber que Baco tem a oferecer à Ariadna algo que ele não tem, a imortalidade, Teseu decide abandoná-la.

Portanto, no texto de Tsvetáieva, o ato de Teseu é um ato heroico, já que ele abre mão de seus desejos para possibilitar à Ariadna uma felicidade que ele crê mais completa. Abandonar Ariadna é uma prova que Tsvetáieva nos apresenta da generosidade e do amadurecimento do herói, que acontece ao longo da peça e culmina nesta atitude.

É digno de nota apontar que enquanto deus e herói discutem seu futuro, Ariadna dorme. E, mesmo após ser abandonada na ilha de Naxos, Tsvetáieva não dá voz à personagem, mas segue somente o herói em seu retorno ao lar. O desfecho da personagem na peça é decidido sem que se contemple os seus desejos. Já o final de Teseu o eleva como herói, pois é como "Tsvetaeva's idealization of the male protagonist, who despites his questionable conduct is still portrayed as a hero torn between passion and fate ${ } 41$. Temos, nestes dois personagens centrais, a demonstração da dualidade de comportamentos entre o masculino e o feminino, e em "Ariadna" há um favorecimento para o personagem masculino. Desde o momento em que decide partir com Teseu, Ariadna entrega a ele seu destino e suas vontades, abre mão de suas escolhas. O mesmo não acontecerá com a próxima amada de Teseu, Fedra, que se posiciona de tal forma que suas vontades jamais possam ser subjugadas, mesmo que isso lhe custe a vida.

\section{Fedra}

A segunda peça da trilogia pensada por Marina Tsvetáieva é "Fedra". A personagem-título da obra é irmã de Ariadna e a jovem esposa do velho Teseu.

\footnotetext{
${ }^{40}$ Id., ibid., p. XIV.

${ }^{41}$ Id., ibid., p. XV.
} 
Antes de se casar com Fedra, Teseu se casou com uma amazona, Hipólita, e juntos tiveram um filho: Hipólito. O enredo, portanto, que Tsvetáieva nos traz é a paixão de Fedra por seu enteado e as complicações daí decorrentes. É inevitável termos em mente, ao ler "Fedra", o "Hipólito" de Eurípedes, já que os enredos giram em torno do mesmo mito.

"Fedra" é uma peça em quatro atos, sem cenas demarcadas e com reduzida quantidade de personagens, se compararmos com "Ariadna": Fedra, Teseu, Hipólito, enfermeira, empregado da casa, amigos, empregadas da casa. Na obra, Tsvetáieva segue preceitos aristotélicos para a tragédia, como a unidade de tempo, contudo, tal qual em "Ariadna", busca dar sua reinterpretação da mitológica paixão de Fedra por seu enteado, e o faz principalmente ao deixar clara sua posição quanto à possibilidade feminina de articulação dos seus sentimentos, principalmente sua sexualidade.

O ciclo de poemas Fedra presente em Depois da Rússia é a primeira demonstração do imaginário que viria se concretizar na segunda peça da trilogia Teseu. E o primeiro poema que Tsvetáieva nos apresenta no ciclo trata justamente do padecimento físico de Fedra diante de impossibilidade de consumar sua paixão. Vejamos:

Lamentação

Hipólito! Hipólito! Dói!

Queima... Ardem as faces...

Cruel horror, escondido

Em Hipólito: o nome!

Como onda demorada

Contra a costa de granito

Por Hipólito inflamada!

Seu delírio e jura!

Mão na terra - até os ombros!

Dentes no cascalho - em migalhas!...

Unidos chorar e jazer!

A mente ao rubro pega fogo...

Como o pó de Herculano - na boca

$\mathrm{E}$ as narinas... Assim me murcho... E me cego

Hipólito, pior que os dentes

Da serra, e seco: areia e cinza!

A vareja no pranto aberto

Da ferida a latejar... Raivosa...

É - galope de égua ardorosa 
Tanto em "Ariadna" quanto em "Fedra" Marina mostra no texto dramático sua preocupação com a voz da mulher que, se na primeira peça é abafada, na segunda coloca-se diretamente, como no poema presente em Depois da Rússia. Mesmo consciente da dificuldade que se impõe entre si e Hipólito, Fedra deixa claro a ele seu desejo. Das dificuldades que se entravam nesta (não) relação, já comentamos sobre o fato de Hipólito ser enteado, filho da esposa anterior de Teseu, marido atual de Fedra. Além disso, logo no primeiro ato, ao se conhecerem, Hipólito diz à Fedra que serve Artemis, a deusa virgem, e pergunta que deus Fedra serve. Ela responde: Afrodite, a deusa da paixão. A impossibilidade do amor, portanto, impõe-se também no plano das relações transcendentais. A questão da relação familiar entre Fedra e Hipólito não recebe a importância costumeira na peça de Tsvetáieva, uma vez que outras questões vão se estabelecendo como impedimentos.

No segundo ato da peça, Fedra já está apaixonada e seu sentimento também se manifesta fisicamente; ela comenta com a enfermeira sobre as fortes batidas que solapam seu coração, comparando-as aos galopes de cavalos (imagem também presente no ciclo de poemas "Fedra") e confessa que a razão disso é Hipólito. Fedra encontra na enfermeira uma incentivadora para que vá em busca de sua satisfação, motivando-a ao dizer que o amor deve ser soberano diante de toda e qualquer lealdade. Assim como na peça de Eurípedes, a enfermeira enumera para Fedra os sucessivos casos de mulheres apaixonadas que acabaram em desgraça, sugerindo uma maldição hereditária que necessita ser rompida.

Depois de um ato completamente voltado aos sentimentos da personagem central, temos um ato dedicado a apresentar as razões da castidade de Hipólito. Além de ser servo da deusa Artemis, virgem e, por isso, acreditar que está acima dos poderes de paixão, ou seja, de Afrodite, o jovem tem razões familiares para não amar mulher alguma. O empregado conta a Hipólito a vida de sua mãe como amazona. Também conta que Hippolita morreu em batalha, defendendo Atenas da invasão das próprias amazonas, mas não por amor a Teseu, e sim por amor a seu filho.

${ }^{42}$ TSVETÁIEVA, M. Depois da Rússia, trad. Nina Guerra e Filipe Guerra. Lisboa: Relógio d’Água, 2001, p. 159. 
The image of Hippolyta as a woman who did not love her husband and who fought for her son is more valuable. Hippolyta, to the end, was entirely within the female kingdom. Theseus, to the end, was enemy for her son. Just the same ([concerning] relations with woman) is Hippolytus. ${ }^{43}$

Segundo a própria Tsvetáieva, como supracitado, o argumento de um filho que foi salvo pela mãe em batalha, que pela batalha ficou órfão era o mais forte possível para a peça, para dar razão à castidade de Hipólito, mais forte que sua devoção à Artemis: assim como sua mãe somente o amou, ele somente amará sua mãe. A mulher dividida entre dois papeis: a guerreira e a mãe, dualidade é representada pelos seios da amazona: um que serve à batalha e outro que alimenta a criança. A devoção pela deusa grega da caça, da batalha e da virgindade o faz repudiar toda mulher que não seja amazona como era sua mãe. E o repúdio é manifesto quando, no ato seguinte, recebe a carta de Fedra e mais tarde, novamente, ao dialogar com a própria Fedra, ao final do ato, rejeitando o último e desesperado pedido da heroína: que juntos morram.

O último ato começa com Fedra dormindo, debilitada, enquanto é assistida pela enfermeira, personagem de maior importância para que as ações sejam articuladas. Ao perceber que Teseu aproxima-se, prepara uma história para explicar porque Fedra encontra-se prostrada, de cama: Hipólito tentou seduzir a esposa do próprio pai. Teseu imediatamente enfurece-se com o filho, declarando inclusive que ele nada mais é seu. Após negar seu filho, pede ao deus Poseidon que o mate. Por meio do coro, sabe-se que tal ato se concretiza. Depois, através do empregado, Teseu sabe que foi Fedra quem tentou seduzir seu filho e então arrepende-se amargamente de seus atos.

Diante das constantes negativas de Hipólito, Fedra reconhece a si como uma pessoa isolada do mundo a seu redor. Mesmo tendo Teseu a seu lado, ela não o ama. A solidão de Fedra pode ser vista como uma projeção dramática dos sentimentos da própria Marina, autoexilada de seu país há tantos anos. O silêncio de Ariadna também pode trazer esse aspecto biográfico, como uma voz que existe, mas é abafada, afastada, tratada como desimportante. Tsvetáieva, como sabemos

${ }^{43}$ MAKIN, M.. Marina Tsvetaeva: The Poetics of Appropriation. Oxford: Clarendon Press, 1993, p. 268, apud., Z. Torlone, M. Fox, op. cit., p. XVIII. 
pelos seus escritos pessoais, não se adaptou ao grupo de emigrados russos que estavam em Paris, República Tcheca ou Alemanha o que, como diz Todoróv, é mais uma demonstração da "insubordinação ao coletivo" ${ }^{4}$. Nas palavras da própria poeta:

\begin{abstract}
Então, entendo-me mal com a emigração russa, vivo quase que só com meus cadernos - e minhas dívidas - e, se vez ou outra minha voz faz-se ouvir, é sempre a verdade, sem cálculo nenhum. [...] Estou completamente sozinha, tanto na vida quanto no trabalho - como em todas as escolas de minha infância: no estrangeiro - "a russa", na Rússia - "a estrangeira" - com muitos amigos que nunca vi e não verei jamais. Completamente sozinha - com minha voz. ${ }^{45}$
\end{abstract}

Além desse traço em comum, as peças comprovam que a maior preocupação de Tsvetáieva na composição do texto trágico é o relacionamento malfadado, que culmina no isolamento da personagem-título que falha ou age inadequadamente em sua busca por afeto. Alguns dos aspectos que Tsvetáeva traz para as peças clássicas já estão presentes na sua primeira experiência como dramaturga, no ciclo Romantika, tais como referências à mitologia clássica, a apropriação de uma "mitologia" moderna (representada pelos personagens sedutores) e o apreço pelo tema do desamor ou, em muitos casos, pela impossibilidade do relacionamento homem-mulher ser fruto de plena felicidade.

\title{
Romantika
}

Já comentamos sobre a situação da Rússia e da poeta em 1918, quando se envolvera com o terceiro teatro-estúdio e escreve seu primeiro ciclo dramático. Marina não teve o gênero dramático como prioridade na sua carreira de escritora, mas os seus momentos envolvida com o drama trouxeram dois importantes ciclos de peças que ajudam muito na percepção da vida e poética de Marina Tsvetáieva. O último ciclo a que se dedicou foi, como apontamos, a trilogia não finalizada Teseu, mas nos interessa analisar especialmente o ciclo de maior volume e de maior significado na breve carreira de dramaturga de Tsvetáieva, Romantika.

\footnotetext{
44 TODOROV, T., op. cit., p. 30.

${ }^{45}$ TSVETÁIEVA, M. Vivendo sobre o fogo: confissões, op. cit., p. 390.
} 
O teatro de Tsvetáieva nunca foi encenado enquanto a poeta viveu. Somente uma das peças de Romantika, "Tempestade de neve" foi uma vez objeto de uma leitura cênica feita pela própria autora. Segundo Hélene Henry, uma das únicas especialistas em Tsvetáieva no mundo que se dedicou ao estudo de Romantika ${ }^{46} \mathrm{e}$ tradutora do ciclo para o francês, "Tempestade de neve" foi bem aceita por todos no teatro-estúdio, que receberam a obra com entusiasmo, mas nunca chegaram a concretizar algum trabalho que envolvesse o material. Apesar de Tsvetáieva ter buscado ao escrever Romantika a forma teatral, como algo realizável, o teatro tsvetáievano é essencialmente lírico, como disse a própria poeta sobre a última peça do ciclo, Fênix. Só o poema é capaz de realizar-se absolutamente, portanto, o teatro deve deixar de ser teatro para que possa existir diante do absoluto. Marina, no entanto, cria um texto teatral que assume o direito de ser tratado como poesia. Porém, antes de entender o lugar de Romantika como poesia, é importante entendê-lo como drama.

As seis peças que integram o ciclo flertam com o teatro tradicional. São situações, paixões, conflitos bem delimitados, personagens centrais delineados e sempre acompanhados de comparsas pitorescos; alguns monólogos quase filosóficos ou diálogos que se desenham como em golpes de esgrima verbal. A construção do verso se dá ora em tetrâmetro ora em pentâmetro, muitas vezes sem rimas; mas em Fênix o ritmo e a rima oriundos do verso tetrâmetro onieguiano trazem ao texto uma densidade especial que não vemos nas outras peças. Além disso, é forte uma influência neo-romântica que se pode notar além do tema dos encontros e desencontros amorosos: o individualismo, a busca pelo prazer e a busca por seu próprio destino fazem dos dramas de Tsvetáieva obras de certa forma ligadas ao romantismo. Há também notas simbolistas fortes, como os elementos da natureza tão recorrentes e que sempre são presságio ou símbolo de algum acontecimento: a lua, o fogo, a tempestade tornam-se signos da dimensão poética do ser absoluto que Tsvetáieva parece buscar.

\footnotetext{
${ }^{46}$ Ao visitarmos o Museu Marina Tsvetáieva em Moscou (em outubro de 2013), tivemos acesso às publicações já feitas em todo o mundo de traduções de livros de Marina e somente dois especialistas dedicaram-se ao estudo de Romantika, H. Henry (tradutora francesa de Romantika) e Jos Holtzer (tradutor holandês do teatro completo de Marina).
} 
Além disso, o resgate de personagens históricos, principalmente Casanova, mostra como Romantika está inserido no universo tsvetáievano. O personagem reverbera o tom da coletânea Verstas II, como citamos no capítulo anterior e também é presença constante nos diários da poeta, como na passagem escrita em 1933, em que Tsvetáieva, já mais velha e há alguns anos fora de Moscou, faz uma avaliação de sua vida: "O projeto de minha vida era: ser amada aos dezessete por Casanova (um estrangeiro!) - ser abandonada - e educar um filho dele, maravilhoso. E depois - amar a todos" ${ }^{\$ 7}$. E, podemos ainda questionar, não seria Casanova (apesar de ter de fato existido, diferente de D. Juan, por exemplo) um tipo de ser mitológico mais "moderno"? Acreditamos que sim, afinal, o imaginário e as lendas que cercam o famoso sedutor passam de geração em geração, chegando a inspirar filmes, livros e demais produções artísticas até hoje.

História e psicologia são, em Romantika, apenas a superfície das diferentes tessituras das peças. Os personagens do dramas romanticos se movem além do tempo, além da realidade, através do espaço convencional da poesia. O tempo, as horas, os dias têm outro valor. Aí Tsvetáieva encontra seu desafio cênico: montar o etéreo no teatro, expressão artística tão marcada pela materialidade sígnica. Henri acredita inclusive na leitura de cada personagem como voz de um poeta: "Les destins de Casanova, d'Henrietta, de Lauzun questionnent, au-delà de l' 'aventure', un destin des poètes et de la poésie, ambassadrice de Psyché en notre monde ${ }^{\sharp 8}$. A relação entre os personagens das peças românticas de Marina com os poetas e, principalmente, a relação da própria Marina com seus personagens pode ser analisada como uma "escrita performática". Por "escrita performática" (ou “escrita como performance") podemos entender a transmutação de Tsvetáieva em cada um dos personagens que ela criou, como se fosse autora e atriz de cada um dos papéis presentes em Romantika ${ }^{49}$. Vamos analisar essa transmutação de Tsvetáieva em seus personagens quando nos aprofundarmos nos comentários sobre a peça que é objeto de nosso trabalho, Uma aventura, no segundo capítulo dessa dissertação.

\footnotetext{
${ }^{47}$ TSVETÁIEVA, M. Vivendo sobre o fogo: confissões, op. cit., p. 306.

${ }^{48}$ HENRI, H. op. cit., p. 19.

${ }^{49}$ Para aprofundar-se nesta proposta analítica, indicamos a leitura de "Wrinting as a Performance: The Case of Marina Tsvetáieva", de Alexandra Smith. O artigo foi publicado no New Zeland Slavonic Journal, 2003, p. 143-53.
} 
Assim como toda a obra da poeta, não é possível classificar a dramaturgia de Tsvetáieva dentro dos moldes da literatura então existente. Não é realista ("teatro do sonho", como a autora o chamou, não pode mesmo ser um teatro fiel à representação do real), nem simbolista, pensando em suas vertentes mais teóricas, como nos mostra Henri ${ }^{50}$. Contudo, trata-se de um teatro que dialoga com referências e estereótipos já consagrados nos palcos ou mesmo consagrados na cultura, como é o caso do Embaixador francês e do Embaixador espanhol que aparecem no terceiro ato de Uma aventura, que são representações da visão mais estereotipada que se pode ter de um espanhol e de um francês. Tsvetáieva faz, portanto, exercícios de fórmulas teatrais, como já fizera, por exemplo, Aleksandr Blok ao buscar na commedia dell'arte a referência para a sua "Barraquinha de feira".

Além dessa relação com Blok, é possível relacionar Romantika a um outro ciclo de pequenos dramas de um poeta também não muito profícuo na arte dramática: Pequenas tragédias, de Aleksandr Púchkin. Também escritas num repente, as cinco pequenas peças de Púchkin se revelam como um possível modelo para o ciclo que Tsvetáieva compôs.

\begin{abstract}
Pouchkine a beaucoup hésité avant d'assigner à ses pièces une dénomination: scènes dramatiques, esquisses dramatiques, études dramatiques, essai d'étude dramatique. Tsvetaïeva, publiant en 1922 "La fin de Casanova", a chosi "essai dramatique". Cela suffit à signer une appartenance commune à un théâtre de la réflexion et de l'expérimentation, où la convention théâtrale et l'émotion dramatique sont mises, on l'a vu, au service de la quête de définition. ${ }^{51}$
\end{abstract}

É possível ler as Pequenas tragédias como peças ligadas ao romantismo, de cunho psicológico, especialmente pelo individualismo presente nos personagens, e a busca pelo etéreo, que também encontramos em Tsvetáieva. Segundo Perpétuo Franco:

Svetlana Evdokimova, na introdução de Alexander Pushkin's little tragedies, nota a afinidade entre as obras de Púchkin e outras experimentações de autores românticos europeus "especialmente aqueles que procuram explorar o potencial do monodrama e transformá-lo em uma nova tragédia romântica, como Wordsworth e Byron"; esta nova tragédia romântica, de

\footnotetext{
${ }^{50}$ HENRI, H. op. cit., p. 22.

${ }^{51}$ Id., ibid., p. 24.
} 
cunho psicológico, não teria mais como prioridade a ação externa, e sim o personagem, seu mundo interior e seus estados de alma. ${ }^{52}$

A fala de Mozart, na peça "Mozart e Salieri" explicita bem essa vertente do teatro puchkiniano, que ecoa em Romantika:

\author{
Ah, se todos sentissem desse jeito a força \\ Da harmonia! Ah, não: desse jeito \\ O mundo não teria como perdurar; ninguém ia ficar \\ Se inquietando com as necessidades da vidinha cotidiana; \\ Todos se entregariam com gosto à arte. \\ Somos os poucos escolhidos, os felizes ociosos, \\ Desprezamos as coisas úteis e miseráveis, \\ E somos os sacerdotes da beleza pura. ${ }^{53}$
}

As Pequenas tragédias ainda voltarão à nossa análise. Uma em especial nos interessará para comentarmos mais detalhadamente Uma aventura. Mas, desde já, podemos declarar que Mozart, especialmente Don Giovanni, presente na obra dramática de Púchkin também é lembrado por Marina Tsvetáieva, o que estreita ainda mais os laços dialógicos entre os ciclos dramáticos.

Romantika, segundo Henri e também conforme minhas próprias observações, não é um tema ainda caro aos estudiosos de Tsvetáveia em todo mundo, mas publicações recentes, como o texto de Alexandra Smith, as traduções de Torlone e Fox e a própria tradução de Romantika para o francês mostram que não há em Marina Tsvetáieva escritos que não sejam dignos de tradução e pesquisa. Com a tradução e análise de Uma aventura, pretendemos abrir caminho para que essa área da poética de Tsvetáieva seja alvo de pesquisas nos estudos russos também no Brasil.

\footnotetext{
52 PERPÉTUO FRANCO, I. "Posfácio" in A. Puchkin, Pequenas tragédias, trad., notas e posfácio Irineu Franco Perpétuo. São Paulo: Globo, 2006, p. 47.

${ }^{53}$ PUCHKIN, A. Pequenas tragédias, op. cit., p. 113.
} 


\section{Capítulo 2}

\section{MARINA TSVETÁIEVA - UMA AVENTURA NO DRAMA}

\section{Apontamentos de análise}

A ação de Uma aventura transcorre no século XVIII, na Itália e, como informado logo de início aos leitores, Marina buscou como fonte o tomo $\mathrm{V}$ das Memórias de Casanova ${ }^{54}$, de onde foi retirada a epígrafe que abre a peça: uma frase da amante do conquistador (e personagem central de Uma aventura) sobre si mesma: "Esquecerás também Henrietta"

A estrutura da obra é composta por cinco atos sem divisão de cena. O tempo e o espaço variam ao longo dos atos, sem qualquer compromisso com a realidade fenomênica. Um exemplo é a passagem do segundo para o terceiro ato: não sabemos como, nem por quais meios e nem por quê ela ocorre. O único traço histórico que localiza as personagens em outrora é a citação direta do espaço onde ocorre a história nas memórias autobiográficas de Casanova. É característica marcante do texto o diálogo sagaz, rápido, abundante em ecos (como a repetição da palavra "certo" na fala do Embaixador francês no terceiro ato), refletindo em uma crescente tensão entre as personagens. A construção do verso preza pela emulação da fala, apresentando diálogos naturais, pouco empolados e com inversões sintáticas pouco bruscas, que não causariam estranheza aos ouvidos russos. Um jogo de tetrâmetros e pentâmetros iâmbicos, com algumas rimas, domina Uma aventura assim como quase a totalidade das peças do ciclo Romantika, com exceção de Fênix, na qual Marina preferiu fazer uma homenagem a Puchkin e escolheu os versos preponderantes em Evguêni Oniêguin.

\footnotetext{
${ }^{54}$ CASANOVA, Giacomo. Memorias. Madri: Aguilas Ediciones, 1982.

${ }^{55} \mathrm{O}$ respeitado biógrafo de Giacomo Casanova Ian Kelly dedicou um capítulo de Casanova: muito além de um grande sedutor (tradução de Roberto Franco Valente. Rio de Janeiro: Zahar, 2008) ao relacionamento de Casanova e Henrietta. O título do capítulo é "Tu também esquecerás Henrietta", fazendo alusão à mesma frase.
} 
Os primeiros quatro atos da peça se passam em 1748, em diferentes cidades da Itália: Cesena, Parma e "outra cidade italiana" ${ }^{56}$. O quinto ato se passa treze anos após o primeiro, isto é, em 1797. A passagem do tempo é fundamental para entendermos a personalidade e as reações do Casanova já mais velho, como veremos mais adiante. Embora tenha um papel central na peça, vale ressaltar que Casanova não é o único protagonista do texto. As ações de Henrietta, jovem amante do conquistador italiano, servem de estopim para o desenvolvimento do enredo. Os demais personagens são secundários, mas auxiliam no desenrolar da ação dramática rumo ao seu desenlace, ainda que sempre circuncritos a um único ato: Capitão e Duque estão presentes no primeiro ato; Proprietária de loja de roupas e suas duas funcionárias estão no segundo ato; Corcunda, o violoncelista Belo Sandro, Pedant, embaixador espanhol, $1^{\circ}$ espanhol, $2^{\circ}$ espanhol, embaixador francês, $1^{\circ}$ francês e $2^{\circ}$ francês são os personagens do terceiro ato; o quarto ato é protagonizado somente pelo casal central; Menina aparece somente no quinto ato. Todos estes personagens são planos, sem nuances psicológicas mais elaboradas e a existência de cada um no enredo da peça está inteiramente ligada ao desenvolvimento dramático do casal central. Na lista de personagens, Tsvetáieva descreve como "marionetes" (марионетки) os seguintes personagens do terceiro ato: embaixador espanhol, $1^{\circ}$ espanhol, $2^{\circ}$ espanhol, embaixador francês, $1^{\circ}$ francês e $2^{\circ}$ francês.

O casal principal da peça não é composto exatamente pelas personagens que esperamos encontrar em uma peça russa do século $\mathrm{XX}$, principalmente se nos debruçarmos sobre outros textos teatrais da época, como a primeira versão de Mistério bufo, de Maiakóvski, escrita no mesmo ano de Uma aventura em $1918 .^{57}$

\footnotetext{
${ }^{56}$ Tempo e local da ação: 1o ato: Quarto de hotel em Cesena, 1748. 2o ato: Mesmo quarto de hotel, 1748. 3o ato: Vila no interior de Parma, 1748. 4o ato: Quarto do Hotel Balança, em outra cidade italiana, 1748. 5o ato: Mesmo quarto de hotel, treze anos depois. Horário dos encontros: tarde e noite. (Время и место встреч I картина - комната гостиницы в Чезене, II картина - та же комната гостиницы, III картина - загородная вилла в Парме, IV картина - комната гостиницы “Весы” в другом итальянском городе - 1748 г. V картина - та же комната гостиницы, 13 лет спустя Час встреч: вечер и ночь).

${ }^{57}$ Para maiores informações sobre Mistério bufo, cf. Arlete Cavaliere, "Nota à presente edição" e “O teatro de Maiakóvski: mistério ou bufo?” in Vladímir Maiakóvski, Mistério bufo, trad. Arlete Cavaliere. São Paulo: 34, 2012
} 
É indispensável ter em mente que Tsvetáieva escreveu no período da Moscou revolucionária para a apreensão das possíveis representações de figuras como Casanova e Henrietta no texto ${ }^{58}$.

Segundo a biografia de Kelly ${ }^{59}$, Giacomo Casanova andava errante pela Europa, tentando fugir das últimas paixões que causara, quando se instalou num hotel da cidade italiana de Cesena. Mas antes de nos voltarmos para a história que se encontra nas biografias de Giacomo Casanova, é importante captarmos o enredo de Uma aventura.

A peça de Tsvetáieva começa com Casanova dormindo no hotel, sem qualquer explicação de como e porque o conquistador estava lá. No meio da noite, enquanto ele dorme em um quarto com um mapa estrelar preso à parede e livros espalhados pelo chão, entra um hussardo, Henri, que viaja acompanhado por outro cavaleiro, o Capitão. Nesse começo, enquanto sonha, Casanova balbucia nomes de mulheres e títulos de livros. Henri acorda Casanova ao acaso, derramando nele uma gota de óleo.

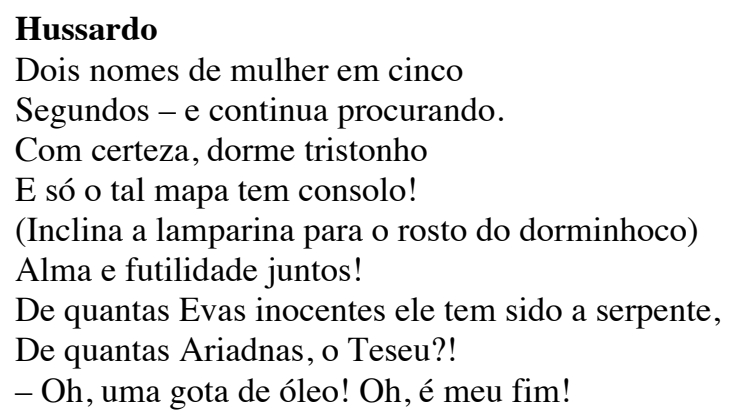

\section{Casanova (saltando na escuridão)}

Quem está aí?

Le-duque? Socorro! Sbirri! Morte! Rosina!

\footnotetext{
58 Apesar da estranheza que causa essa temática alicerçada em tempos tão diversos dos quais Tsvetáieva vivia, vale lembrar que ela não é a única dramaturga a trazer elementos do passado europeu para o teatro russo do século Xx. Basta lembrarmos de "Barraquinha de feira", de Aleksandr Blok, que como já mencionamos buscou na commedia dell'arte a base para seu texto. Além disso, vale lembrar que o século XVIII guarda em seu seio, assim como o século XX, uma grande revolução, a Revolução Francesa. Portanto, diferente do que pode nos dizer o sensocomum, Marina não se alienou completamente de seu tempo ao dedicar-se às paixões de Casanova, como veremos.
}

${ }^{59}$ KELLY, I. op. cit., p. 111. 
Aqui Tsvetáieva faz uma referencia à mitologia (que é uma fonte de inspiração constante principalmente em outras composições, como vimos): Psiquê, proibida de ver a face do marido Cupido, decide quebrar a proibição e se aproxima dele, no meio da noite, com uma lamparina; uma gota de óleo da lamparina cai em Cupido e o desperta, o que provoca a separação do casal ${ }^{60}$. Também as outras referências mitológicas do trecho (Teseu e serpente) são interessantes de comentar, já que mostram como aquele Hussardo tinha uma imagem e uma avaliação moral sobre Casanova mesmo antes de dialogarem. Ao compará-lo a Teseu e à serpente, Henrietta deixa claro que a fama do conquistador já havia se espalhado e que ela já sabia exatamente no quarto de quem estava. É possível crer que ela, vestida como Hussardo, não entrara num quarto qualquer, ao acaso, mas que tenha procurado entrar no quarto do legendário veneziano.

Depois de acordado, Casanova interroga Hussardo até descobrir que viaja com um homem mais velho, o Capitão, e que seu nome é Henri. No fim do ato, será revelado que Henri/Hussardo é Henrietta e que ela adotara uma identidade masculina porque, segundo nos elucida o texto de Kelly ${ }^{61}$, isto era necessário para que a mulher tivesse alguma liberdade ao viajar sozinha pela Europa à época. Henrietta e Casanova apaixonam-se perdidamente e começam a viver, já no primeiro ato, uma breve história de amor repleta de simbolismos ligados à natureza (o maior deles, sem dúvida, a presença constante da lua. Tsvetáieva, na lista de personagens, chega a descrever Henrietta como "luz da lua").

Casanova, tanto em Uma aventura como nas biografias (tanto nas escritas por ele quanto nas escritas sobre ele), nunca havia se apaixonado tão perdidamente por ninguém, como fica sugerido no fim do primeiro ato e evidente no início do segundo. A primeira fala de Casanova no segundo ato é uma declaração de amor, e Casanova segue se declarando enquanto Henrietta (ainda apresentada como "Henri" por Tsvetáieva, ao introduzir as falas da personagem) mostra-se indiferente, quase desconfiada, e até chega a extorqui-lo, pedindo dinheiro, o que

\footnotetext{
${ }^{60}$ Para mais informações sobre Psiquê e Cupido, indicamos a leitura do capítulo XI de $O$ livro de ouro da mitologia: histórias de deuses e heróis (Cf. bibliografia).

${ }^{61}$ "Seu travestismo [de Henrietta] era um sinal de emancipação sexual e social”, I. Kelly, op., cit., p. 112.
} 
ele imediatamente aceita e ainda oferece mais, chegando a lhe dar um anel de ouro e diamantes, do qual ela faz pouco caso:

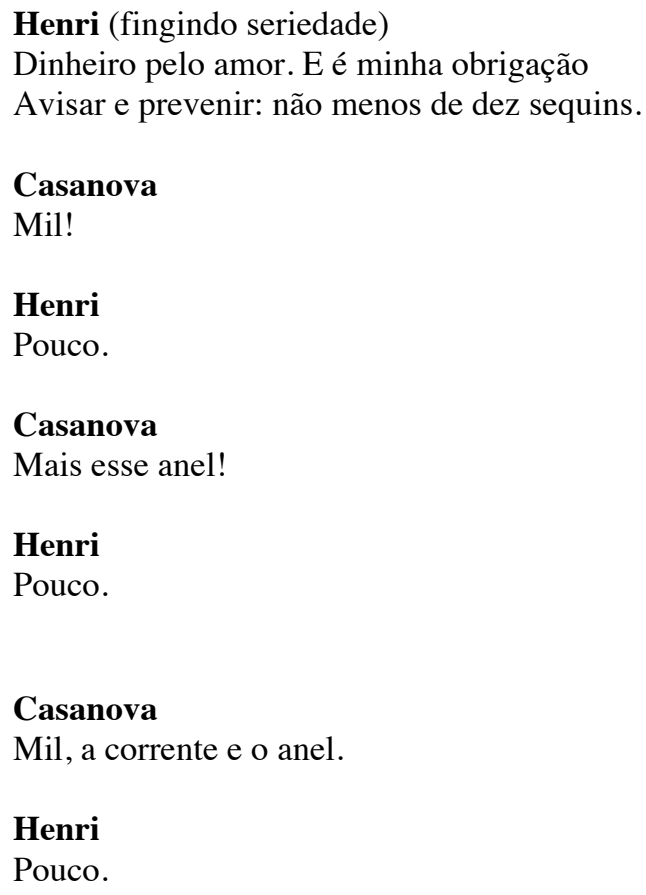

Também é no segundo ato da peça que ele recebe a Proprietária de uma confecção de roupas em seu quarto de hotel. A Proprietária procura a "signora" (синьора), com roupas novas feitas sob medida, o que demonstra que Casanova a havia chamado em algum dia anterior para agradar outra mulher. O diálogo em que Casanova explica à Proprietária que não há outra mulher além da que está diante dele, e que a Proprietária não consegue ver (já que quem está diante deles é Henri, isto é, Henrietta vestida como homem), este diálogo dá à peça certo momento de humor, ou até mesmo de comédia de erros:

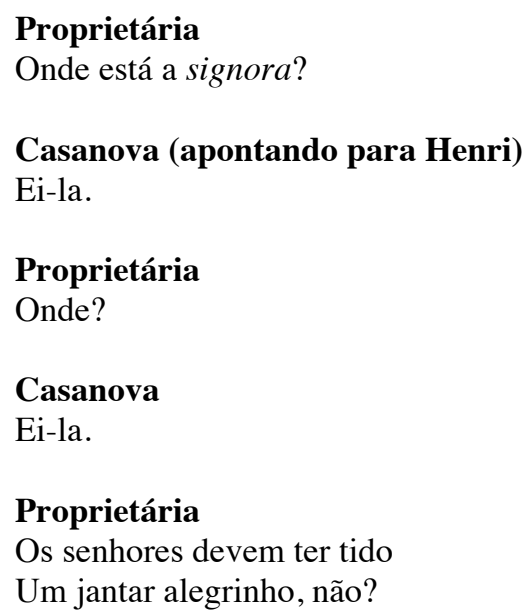




\section{Casanova}

Estou lhe dizendo,

Eis a signora!

\section{Proprietária}

Juro por tudo que há de sagrado

Que signora não vejo nesse quarto...

Muito pelo contrário.

\section{Casanova}

Para por logo fim à discussão:

A signora, cansada da

Sem rigor moda feminina,

Jogou no jardim a luvinha,

Deixou de ser a senhorita...

Agora se fez signor.

\section{Proprietária}

Sim, claro - que inépcia

(para as artesãs)

Vejam, minhas filhas, que peripécia!

(para Casanova)

Senhor, como pode ser? Loira era

a signora que vi. Esta aqui é morena.

$\mathrm{E}$ - oh! - mais gordinha...

E o rosto - uma lua redonda!

Jamais me confundiria.

Casanova (com um riso falso)

Confundiu-se por completo, costureira.

\section{Proprietária (acalorada)}

Como pode ser, senhor?

O senhor nos lábios a beijou,

E ainda de Rosina a chamou:

"Rosina, rainha minha".

Quando o mal entendido tem fim, a Proprietária e as artesãs que com ela trabalham entregam vestidos para que Henrietta possa prová-los e, assim, finalmente deixar de usar roupas masculinas.

Ao saírem de cena Proprietária, Henri e as artesãs para as provas de roupas, Casanova é mais uma vez surpreendido por uma visita. Dessa vez se trata do Capitão, o homem húngaro com quem Henrietta viajava há três semanas. Ele conta a Casanova como conheceu e o que sabe dela. A conversa de ambos é interrompida pela volta das damas à cena. Henrietta (pela primeira vez aparece "Henrietta" como personagem, e não mais Henri ou Hussardo) está usando um vestido, trajes femininos da época, e encanta aos cavalheiros. Novamente a sós, 
Casanova diz à Henrietta: "Era lobo, agora serei cordeiro". O conquistador enfim fora conquistado.

O terceiro ato, "Violoncelo", é o que mais demonstra a atmosfera de sonho que, como citamos, caracteriza todo o ciclo Romantika. Ele se passa em Parma, numa festa num jardim da casa do personagem Corcunda. Não sabemos como e porque Herietta e Casanova estão lá com outros vários personagens, que ainda não haviam aparecido no texto. Os personagens, todos homens, são os oficiais espanhóis e franceses (o que indica que a festa é da alta sociedade), o intelectual Pedant e o disforme anfitrião. Todos eles ficam abertamente encantados com Henrietta, com sua beleza e com sua sensibilidade. Ela, apesar de alegrar-se com os galanteios, deixa claro seu envolvimento exclusivo com Casanova.

$\mathrm{O}$ personagem mais interessante desse ato (e talvez o personagem mais complexo além do casal de protagonistas em toda a peça) é o violoncelista Belo Sandro. De alma artística e misteriosa, Sandro tem falas sempre muito desconectadas da realidade externa, olhando muito para dentro de si e se sensibilizando com a atmosfera onírica da festa. Ele não é um dos convidados da festa, mas sim alguém que é chamado pelo Corcunda para oferecer música aos convidados, quando Henrietta expressa a vontade de dançar.

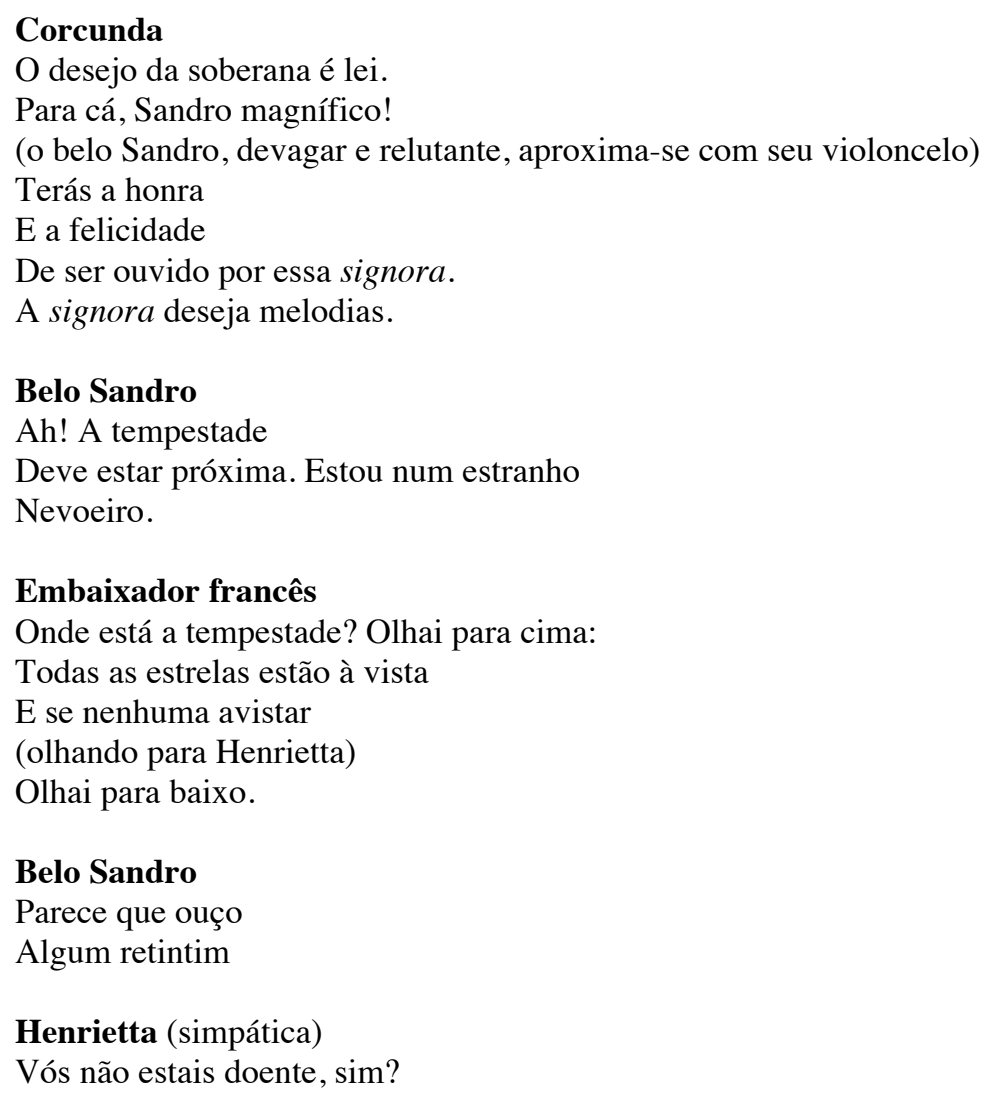




\section{Belo Sandro}

Sim, adoeço. Não consigo tocar.

\section{Corcunda}

Músicos - pessoas estranhas!

Querem que imploremos por horas, anos, séculos...

Henrietta (olhando carinhosamente para Sandro)

Não se pode zangar com tais extravagâncias

Como mulheres: tocam como querem,

Quando querem, para quem querem...

(Para Sandro estendendo a mão)

Maestro,

Sois meu aliado.

Belo Sandro (inclinando-se)

Como o arco e a acorda.

Henrietta (aproximando-se do violoncelo)

Vamos ver se ainda somos amigos,

Violoncelo, alma da minha alma?

(ela senta e toca)

\section{Alguém \\ Estou dormindo?}

\section{Outra voz}

Não, é um sonho que sonhamos.

Os homens, ligados demais às coisas terrenas, não têm sensibilidade para entender o Belo Sandro, mas ele encontra em Henrietta uma interlocutora. Ela prova de fato ser seu par em alma ao tocar o mesmo instrumento de Sandro e emocionar a plateia. Ao finalizar seu número, Henrietta recebe das mãos do Corcunda uma carta que acabara de chegar. Assustada, percebe: sete carimbos. Diz a Casanova, na última fala do ato: "Meu amor - devemos separar-nos".

Diante dessa nova realidade começa o quarto ato. O casal num quarto do Hotel Balança em "outra cidade italiana". Henrietta de malas prontas e nervosa para partir. Casanova magoado, já que ele desejava unir-se eternamente à Henrietta. Ela, todavia, não pôde aceitar, ainda mais diante da misteriosa carta que a fez querer partir. A estabilidade do relacionamento, que parecia existir no ato anterior, desaparece. A despedida do casal é conturbada e Casanova não aceita o abandono.

Henrietta (e por um segundo, Henri)

Como um lobo branco - é um Casanova fiel!

(mudando o tom)

Só mais uma coisa: nunca e em lugar algum 
Tente descobrir quem sou eu - ou me condenarão à morte.

E mais uma coisa: ama

Uma outra. Uma outra, não. Ama a todas. Loucuras -

Três eu fiz em minha curta vida.

$\mathrm{Tu}$ - és a terceira e última - e derradeira.

Que horas são?

Casanova

Então vais sozinha?

\section{Henrietta}

Sim, assim como eu cheguei.

\section{Casanova}

Não, isso não pode ser!

\section{Henrietta}

Tudo é possível sob a lua!

(luz da lua)

Olha, a lua

Será os lampiões acesos pelo caminho...

Henrietta, apesar de ter uma razão secreta para partir contida na carta, também parece duvidar da possibilidade de amar. Antes de partir e desconfiando que possa "Casanova ser fiel", arranha uma frase no vidro da janela do quarto de hotel com um anel de ouro que ganhou do parceiro no primeiro ato. Depois, vai embora e abandona o jovem apaixonado (que tem 23 anos nesse momento da ação) no quarto de hotel, e assim acaba o quarto ato.

Casanova não superou aquele amor, o que podemos comprovar no quinto e último ato da peça, que se passa treze anos depois dos demais. Chegando, sem perceber, na mesma cidade (que não sabemos qual é), no mesmo quarto do mesmo Hotel Balança, Casanova, agora com 36 anos, já não se parece em quase nada com o Casanova de outrora. Acompanhado de uma menina italiana de dezessete anos, já aparenta ser, finalmente, o Casanova cuja fama se espalhou pelou mundo: devasso, unicamente preocupado em tirar o máximo proveito de uma jovem moça e sentimentalmente inacessível:

\footnotetext{
Casanova [à Menina]

O que é pecado?!

O destino de todas as moças é pecar e chorar,

E chorar e pecar, e chorar de novo,

E depois as casulas da igreja bordar.
}

A Menina, sem conhecer a história de amor de treze anos atrás, encontra por acaso a lembrança do relacionamento com Henrietta: 


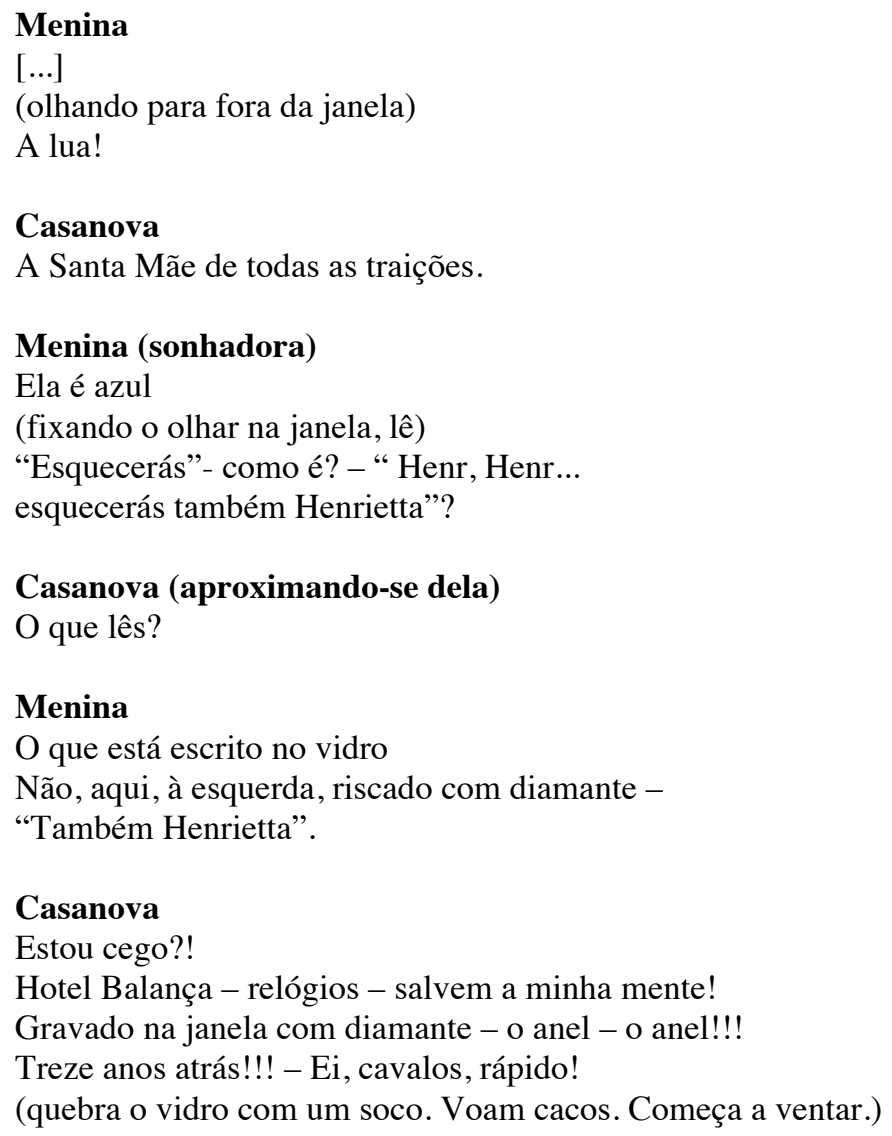

Além de trazer à memória a imagem da lua, que era tão cara a Henrietta (e que, claramente, marcou Casanova com rancor: "a Santa Mãe de todas as traições"), a Menina consegue ler o que foi riscado com o anel de diamante no vidro, há treze anos. Casanova reage de forma catártica e se desespera diante das memórias e, ainda mais, diante da coincidência de ter vindo para o mesmo quarto, no mesmo hotel. Depois de algumas falas, todavia, acalma-se com ajuda da Menina e cumpre na prática o que já havia sido sentenciado treze anos antes: esquece Henrietta nos braços de uma amante qualquer.

\section{Biografia e ficção}

Na passagem sobre Henrietta, na biografia de Casanova escrita por Ian Kelly, podemos ver que o enredo que Tsvetáieva cria não é tão diferente do que está registrado nos escritos memorialísticos do famoso sedutor: Giacomo Casanova estava em Cesena, hospedado numa simples pensão, quando ouviu um tumulto no corredor. Ao aproximar-se, viu que um oficial húngaro discutia com o senhorio 
italiano, porém não falavam a mesma língua. O senhorio italiano desconfiava que o húngaro estava abrigando ali uma mulher, o que era crime, e fez questão de chamar os sbirri, guardas da Inquisição, para que resolvessem o imbróglio. Casanova decidiu se envolver, evitou que os impiedosos sbirri chegassem ao quarto do húngaro, percebeu que o senhorio italiano tentava extorquir o húngaro ao levantar a suspeita sobre seu companheiro de viagem, e então serviu de intérprete para que o senhorio e o viajante pudessem se comunicar. E assim os ânimos se acalmaram:

\footnotetext{
E tudo se passou da velha maneira veneziana: um pouco de charme, alguns contatos, alguns olhares enviesados diante das maneiras equivocadas dos homens e da mania que se tinha de depenar os turistas... e tudo foi resolvido. ${ }^{62}$
}

O húngaro logo tratou de agradecer Casanova e lhe contou sobre sua companhia: de fato era uma mulher francesa, vestida como um soldado, cabelos bem curtos, sua amante. Aquele arranjo social e sexual atraiu Casanova imediatamente: ele se encantou pela ousadia, pela beleza e pela inteligência de Henrietta e a chamou, em seus escritos, de "uma aventureira". Ela era a promessa de uma paixão imediata e evanescente. Casanova decidiu, então, falar com o húngaro, pedindo para que ele deixasse Henrietta, liberando-a para ser sua amante. O húngaro concordou e deixou Cesena. Henrietta e Casanova tornaram-se companheiros e amantes naquele momento.

Assim como em Uma aventura, Henrietta conta a Giacomo que já havia feito três loucuras na vida, porém na obra de Tsvetáieva, não temos mais detalhes sobre seu passado; já pela biografia de Casanova descobrimos que uma das loucuras de Henrietta foi ter se separado de seu marido, com quem tinha um filho que abandonara, não sem culpa. Ela também revela a Giacomo que estava de partida para Parma e ele se oferece para ser seu protetor, no lugar do húngaro. São suas palavras, reproduzidas por seu biógrafo:

\footnotetext{
Não sinto só amizade por você. Eu a amo tanto que se torna absolutamente necessário que a posse completa da sua pessoa me faça feliz, ou então que eu permaneça aqui, deixando você ir embora com o oficial... Saiba, madame, que é possível a um
}

\footnotetext{
${ }^{62}$ KELLY, I. op. cit., p. 112.
} 
francês esquecê-la, mas um italiano, a julgar por mim mesmo, nunca teria esse poder. ${ }^{63}$

Ou seja, depois de ter falado com o húngaro, Casanova convence Henrietta de que pode ser seu acompanhante, mas o poder de decisão está todo na mão dela. O começo e o final da relação tornaram-se poderes de Henrietta naquele momento (o que também vemos em Uma aventura: é ela que decide quando se beijarão nos lábios e quando devem se separar). Era a primeira vez que Casanova passava por aquele tipo de situação: entregue e vulnerável diante de uma mulher. Todavia, segundo Kelly, "ela o tratou como um menino apaixonado desde o começo (e é possível que ela fosse quase dez anos mais velha que ele)". Mesmo assim, ela aceitou ir com ele para Parma. Giacomo sentiu que havia encontrado sua alma gêmea.

É interessante saber que a cidade de Parma, no fim dos anos 1740, quando o casal lá chegou, atravessava um ponto crucial de sua história: "[Em 1748] a cidade fora cedida a D. Felipe, o infante da Espanha. Entretanto este fizera, ao mesmo tempo, um casamento muito oportuno com a princesa Louise Elisabeth, filha do rei Luís XV, da França" ${ }^{64}$. Portanto, quando Giacomo e Henrietta chegaram a Parma, a cidade tornava-se cada vez mais francesa e espanhola. Este fator histórico ilumina personagens que poderiam parecer aleatórios em Uma aventura, principalmente aqueles que compõem o terceiro ato: os funcionários das embaixadas francesa e espanhola.

Em Parma, Casanova comprou à Henrietta toda a sorte de itens de indumentária feminina, inclusive um anel de ouro e diamantes, para que ela deixasse de se vestir como um soldado. Tsvetáieva também esteve atenta a isso, já que é por generosidade de Casanova que sua personagem deixa de se vestir como um hussardo. Também em Parma Henrietta mostra seus dotes musicais: ela tocou viola de gamba, um instrumento semelhante ao violoncelo, em um recital que ocorrera na cidade e ao qual havia faltado um músico. A cena também aparece em Uma aventura, quando Henrietta assume o violoncelo do Belo Sandro, que está impossibilitado de tocar. O casal permaneceu em Parma por três meses, descritos por Casanova, segundo Kelly, como os mais felizes de sua jovem vida (na época,

\footnotetext{
${ }^{63}$ Id. ibid., p. 113.

${ }^{64}$ Id. ibid., p. 115.
} 
Casanova tinha por volta de 24 anos). O fim do relacionamento biográfico é similar ao que encontramos na ficção: no que Kelly chama de uma garden-party, Henrietta recebeu uma carta, uma resposta a outra correspondência que enviara e sobre a qual Giocomo não tinha conhecimento. Em sua carta, ao que indicam as memórias de Casanova, ela havia escrito para a sua família na França. Não sabemos o exato conteúdo das cartas, mas elas fizeram com que a amante decidisse partir, para corrigir seu passado. Ela decidiu que era hora de se separarem. Para poder voltar para a França, a família de Henrietta enviou uma quantia de dinheiro que deveria ser retirada num banco em Genebra. Casanova, desorientado e sofrendo, decide ir com ela até lá e, de Genebra, ele voltaria para a Itália e ela seguiria seu próprio caminho. Hospedaram-se no Hôtel des Balances (que Tsvetáieva chama na peça apenas de Hotel Balança) e lá se despediram de forma quase tão intensa como no texto da poeta. Nas palavras de Kelly e do próprio Casanova:

\begin{abstract}
No Hôtel des Balances, em Genebra, eles se separaram. "Nas últimas 24 horas, a única eloquência que podíamos manifestar eram... as lágrimas... Henrietta não tinha esperanças ilusórias... ela me pediu que não procurasse por ela e que fingisse não conhecê-la caso viesse a encontrá-la [novamente]." Ela lhe enviou uma carta do primeiro posto de troca, em Châtillon, dizendo apenas "Adieu", e deixou gravada, com anel de diamante que ele comprara para ela em Parma, uma mensagem na janela do quarto. ${ }^{65}$
\end{abstract}

A mensagem é a mesma que Tsvetáieva usou em sua peça: "Esquecerás também Henrietta". A cena com a Menina criada por Tsvetáieva para compor o último ato não encontra respaldo na biografia de Giacomo Casanova, mas é sabido que ele continuou a vida de sedutor, sem esquecer, porém, aquela mulher vestida de homem que para sempre o tocara. Segundo Kelly, mesmo mais velho ao escrever suas memórias, o conquistador italiano cita Henrietta como a mais memorável mulher que já encontrara, e diz: "não, eu não a esqueci, e é um balsamo para a minha alma toda vez que me recordo dela" ${ }^{\prime 66}$.

Na biografia de Casanova, Kelly conta como foi a reação de Giacomo quando se encontrou novamente com a sentença da ex-amante na janela do Hôtel des

\footnotetext{
${ }^{65}$ Id. ibid., p. 117.

${ }^{66}$ Id, ibid., p. 117.
} 
Balances, em Genebra, treze anos após a despedida: ele não só se assustou como percebeu que não era o homem que pretendia ser, e que a vida passava diante de seus olhos sem que ele se sentisse de alguma forma realizado. Foi o começo de uma crise nervosa que voltaria em outros momentos da sua vida, apoiada pelas alucinações que a sífilis, cada vez mais grave, lhe causava.

Para finalizar essa breve explicação biográfica, temos que apontar que o casal voltou a se comunicar, em Aix-en-Provence, na França, em 1769. Nessa pequenina cidade francesa, Casanova teve uma de suas maiores crises nervosas e alucinações. Na mesma cidade morava Henrietta, que ao saber que estava lá seu antigo amigo e que passava por problemas de saúde, contratou anonimamente uma enfermeira que cuidou de Giacomo até que ele melhorasse. Depois que Casanova descobriu o endereço exato da ex-amante e lhe mandou uma carta os dois mantiveram uma longa correspondência, mas nunca mais se encontraram.

\section{Símbolos, individualismo e paródia}

O texto dramático de Tsvetáieva é repleto de simbologias, traço determinante de sua poética. E o símbolo com maior presença em Uma aventura é a lua, a luz da lua. Sempre relacionada à Henrietta, a lua marca a trajetória do relacionamento do casal central e, como vimos no quinto ato, exaspera Casanova. A lua é repleta de significados e, essencialmente, é um símbolo da passagem do tempo, graças às suas quatro fases, que indicam o começo, o meio e o fim de tudo. Essa primeira definição corresponde ao uso do símbolo que Tsvetáieva fez: a lua nasce com Henrietta (ela já é a "luz da lua" quando descrita na lista de personagens da peça) e acompanha a personagem até a partida definitiva, no quarto ato: "Adeus! solitária - sobre mim e sobre ti/ A lua sem lar". O que guia a personagem em sua fuga é a luz da lua, que tenta vencer a escuridão da noite, como foi Henrietta ao tentar vencer a escuridão dos sentimentos sempre tão individualistas de Casanova. Mas assim como a lua sempre parte para que o dia nasça, o relacionamento do casal central também não foi eterno, como a lua já simbolicamente anunciara durante todo o enredo; e ligada à ideia da noite, a lua é também associada ao sonho, ao devaneio noturno (como foi Henrietta para Casanova: chegou no meio 
da noite, como em sonho e, no meio de uma outra noite, partiu). E, por fim, a lua é metáfora antiga para o feminino, a força da mulher e suas artimanhas ${ }^{67}$.

$\mathrm{Na}$ peça, Tsvetáieva parece indicar um hiato no comportamento ardiloso e conquistador pelo qual Casanova tornou-se conhecido e a razão para esse hiato é Henrietta. Portanto, é interessante perceber que durante quatro atos, enquanto o personagem está sob os efeitos do amor, o leitor não encontra o Casanova imortalizado por sua fama, mas um Casanova às avessas: em vez de conquistador, apaixonado; em vez de volúvel, disposto a se comprometer; em vez de abandonador, o abandonado. Henrietta, portanto, é quem assume o papel do conquistador, daquele que não busca outra coisa em uma relação que não seja sua satisfação pessoal e individual.

É importante termos em mente a inversão dos papéis esperados para cada protagonista, pois falaremos disso com mais minúcia adiante, ao estudarmos Uma aventura como uma obra paródica. Antes, porém, é importante entendermos a construção das personagens, principalmente através do uso do arquétipo do personagem sedutor (que primeiro se manifesta em Henrietta e, só depois, em Casanova, que é o arquétipo do sedutor por excelência).

Ian Watt, na obra Mitos do individualismo moderno, elege quatro mitos ${ }^{68}$ derivados da transição do sistema social e intelectual medievos para o sistema dominado pelo pensamento individualista moderno. Antes de tudo, se faz necessário que definamos “mito" segundo Watt:

\begin{abstract}
A definição de mito com que trabalho no momento de escrever a abertura desse livro é: uma história tradicional largamente conhecida no âmbito da cultura, que é creditada como uma crença histórica ou quase histórica, e que encarna ou simboliza alguns dos valores básicos de uma sociedade. ${ }^{69}$
\end{abstract}

E os mitos modernos eleitos por Watt são Fausto, Dom Quixote, Dom Juan e Robinson Crusoé. Segundo o estudioso, essa transição da Idade Média para a modernidade foi marcada pelo notável desenvolvimento de seus significados originalmente renascentistas para os posteriores significados românticos. O

\footnotetext{
${ }^{67}$ Sobre simbologias, indicamos a leitura do Dicionário de símbolos (cf. bibliografia).

${ }^{68}$ Ian Watt, Mitos do individualismo moderno, trad. Mario Pontes. Rio de Janeiro: Zahar, 1997.

${ }^{69}$ Id. ibid., p. 16
} 
estudioso busca seus mitos na ficção, mas não os vê como simples invenções ficcionais, e sim como "homens de carne e osso e que irão florescer enquanto os

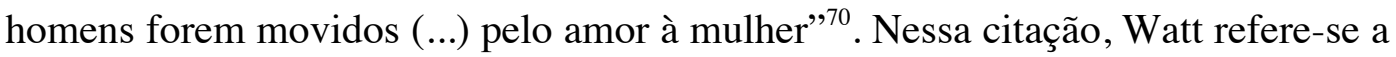
um dos mitos que estuda em seu livro: Dom Juan, o arquétipo daquele que busca suas satisfações amorosas e sexuais sem se preocupar com o outro ou com a conduta social, priorizando apenas manter-se livre de envolvimentos românticos para conquistar novos amantes. Diante dessa definição, podemos afirmar que Casanova, mesmo não sendo um personagem inteiramente ficcional (falamos aqui "inteiramente" porque sua fama vai além de sua existência a ponto de quase transformá-lo num ser ficcional), é portador das características que Watt vê em Dom Juan e por isso é análogo ao sedutor espanhol. O próprio Watt vê em seus mitos a dualidade limítrofe entre o real e o ficcional:

Fausto, Dom Quixote, Dom Juan e Robinson Crusoé existem numa espécie de limbo, onde talvez não sejam vistos como personagens verdadeiramente históricos, mas também não como simples invenções de natureza ficcional. ${ }^{71}$

Podemos ver Casanova como uma desses mitos de Watt: não está somente inscrito como personagem histórico, já que sua vida já se transformou tantas vezes em ficção e sua fama sobrepujou-se sobre sua existência; nem somente como ficção, já que existiu, viveu e deixou relatos e memórias.

Dito isto, interessa-nos reconhecer o Casanova de Tsvetáieva como personagem na filiação de Dom Juan para que possamos tentar entender porque a poeta tanto destacou o personagem em Uma aventura; compreender, portanto, como um personagem sedutor, segundo o arquétipo estabelecido por Watt, seja ele Dom Juan ou Casanova, constrói-se como mito moderno representante do individualismo capaz de se "reinventar" por meio da maestria de Tsvetáieva durante a Moscou de 1918.

Watt afirma que Dom Juan (ou o mito do sedutor, como preferimos) caracteriza-se por querer seguir seu próprio caminho, e não aquele que é tido como o caminho oficial, entrando em conflito, no Renascimento, com a força da ContraReforma, uma vez que valores como moral e justiça são negligenciados pelo

\footnotetext{
${ }^{70}$ Id., ibid., p.14

${ }^{71}$ Id., ibid., p. 15.
} 
sedutor. Podemos fazer um paralelo com Uma aventura: os personagens sedutores que Tsvetáieva põe em cena são o exato oposto do que se deveria representar na época em que Tsvetáieva os criou. Valores como a coletividade, a busca pelo comum, a luta dos trabalhadores passam longe das questões sentimentais da aristocracia europeia que encontramos em Uma aventura.

Podemos aproximar Casanova, Henrietta e Tsvetáieva, pois os três apresentam um traço em comum: os três buscam sua individualidade. Casanova, como Henrietta, decidiu viver sua vida em busca do prazer, mesmo que isso fosse de encontro aos preceitos da Contra-Reforma; Tsvetáieva também decidiu viver sua vida "no absoluto",72, não submetendo sua arte, sua força criativa e sua vida à imposição de qualquer ideologia, mesmo quando isso parecia obrigatório: escolheu não viver uma vida coletiva, mas viver uma vida subjetiva, pessoal, a seu modo, sem abrir mão da individualidade.

Correlacionando o casal central de Uma aventura à biografia de Tsvetáieva, podemos arriscar flagrar em Romantika personagens que, como ela, buscam seu próprio prazer, seus meios subjetivos de vida. Tsvetáieva expressa em sua poética um estilo de vida, a repudiar os esforços em prol da coletivização da sociedade russa da época. Dessa forma, Romantika constitui uma manifestação discreta, sem alardes, mas de forte poder poético, de recusa à ideologia do "coletivo", que o novo regime se propunha a instaurar na Rússia. O ciclo de peças, como podemos ver através de Uma aventura, é um elogio ao individualismo, à busca do "eu" e de seus desejos. É também louvor ao amor, à satisfação íntima do afeto e do sexo e aos relacionamentos de outrora.

Vale ainda ressaltar o papel da mulher, figurado em Henrietta, como senhora absoluta de sua sexualidade e de seu destino, como expressa a própria vida de Tsvetáieva (e que ecoa em suas composições futuras para teatro, como "Ariadna" e "Fedra"). Se sabemos que Marina escreveu o papel de Menina, em Uma aventura, para Sónetchka, a alusão da heroína Henrietta como escrita de si mesma deve ser ponderada, ou melhor, a escrita pode figurar como uma representação de sua ideologia pessoal de vida. A capacidade de Tsvetáieva em se transmutar em seus próprios personagens já foi abordada pela crítica ${ }^{73}$. Podemos, portanto,

\footnotetext{
72 TSVETÁIEVA, M. Vivendo sobre o fogo: confissões, op. cit., p. 139.

${ }^{73}$ A. Smith, op., cit., p. 143-53.
} 
ilustrar essa característica da composição da personagem Henrietta: apesar de Tsvetáieva não ter se vestido de homem e viajado incógnita, como fez sua personagem, é possível apreender em Henrietta traços de sua criadora nas longas falas poéticas (ver no quarto ato, especialmente), na sua atitude em relação ao seu próprio destino, domando-o mesmo diante de imprevistos e no compromisso com sua individualidade. Henrietta, portanto, constitui um exemplo de uma experiência poética comum na obra de Tsvetáieva: a transmutação de sua voz em um eu-lírico ou personagem como escrita de um "eu" autobiográfico.

Henrietta também viveu o papel que desenhou para si, segundo o que Casanova escreveu sobre ela, quando começaram a usar identidades falsas na elegante comunidade de Parma (o que não acontece na peça de Tsvetáieva). Kelly aponta essa interessante coincidência, que permite aproximarmos ainda mais criadora e criatura. Marina e Henrietta: "Pois Henrietta não estava desempenhando um papel: ela era a personagem que representava"74.

A postura envolvente de Henrietta transforma Casanova, ele passa a representar um conquistador às avessas, como já referimos, ou como prefere Linda Hutcheon $^{75}$, podemos considerá-lo um sedutor ironizado, isto é, que age de forma oposta ao que se esperaria do arquétipo que representa. Ao trazer à cena um mito já tão explorado na história da literatura, como é o mito do sedutor, vemos que Tsvetáieva filia-se a outros autores que já se debruçaram sobre o tema do domjuanismo e do casanovismo, tais como Púchkin, Byron e Mozart. Há, neste sentido, elementos paródicos, dialógicos e intertextuais na poética de Tsvetáieva que nos interessa ressaltar.

A paródia é um processo artístico que integra boa parte da criação artística russa, principalmente se levarmos em conta uma definição mais ampla do termo:

No entanto, interessa [...], ao lado da concepção bakhtiniana de paródia, a utilização mais ampla do conceito, de acordo com a acepção etimológica do termo referida pelo poeta e crítico Haroldo de Campos e que encerra a ideia de "canto paralelo" e

\footnotetext{
${ }^{74}$ I. Kelly, op., cit., p. 116.

${ }^{75}$ Linda Hutcheon, Uma teoria da paródia: ensinamentos das formas de arte do século XX, trad. Tereza Louro Pérez. Lisboa/Rio de Janeiro: Edições 70, 1989.
} 
não deve ser necessariamente entendida no sentido de imitação de burlesca. ${ }^{76}$

Entretanto, a definição de Bakhtin ${ }^{77}$ para a paródia (recurso estilístico que tem fim essencialmente cômico) não nos parece pertinente para a apreensão da obra dramática de Marina Tsvetáieva. Mais vale, talvez, focalizar a paródia como um recurso mais amplo, como também considera Hutcheon: "Há de ter-se já tornado claro que aquilo que aqui designo por paródia não é apenas aquela imitação ridicularizadora mencionada nas definições [anteriores]"78.

Dos conquistadores que existiram antes do Casanova de Tsvetáieva, interessanos apontar dois, em especial, pela proximidade da autora com as obras desses artistas. O primeiro, e o mais citado sobre o tema, é Dom Giovanni de Mozart. O segundo é "O convidado de pedra" de Púchkin.

A consagrada ópera Dom Giovanni foi à cena pela primeira vez em Praga, a 1787. O próprio Giacomo Casanova esteve presente na première e, segundo Kelly, ajudara no libreto, que fora escrito por seu amigo Lorenzo da Ponte. O enredo da ópera traz à cena uma representação clássica do mito: o colecionador de conquistas femininas que se abala diante do sobrenatural: a estátua de pedra que aparece para matá-lo e, assim, aplicar justiça a todos os que sofreram em suas mãos. O famoso servo de Dom Giovanni, Leporello, é lembrado nominalmente por Tsvetáieva em Uma aventura, logo quando o Hussardo/Henrietta entra no quarto de Casanova:

\footnotetext{
Hussardo

Não se erguerá para ajudar

Vosso Leporello - E porque:

Nessa noite, não descansará

Do senhor o servo singelo.
}

\footnotetext{
${ }^{76}$ Arlete Cavaliere, "A arte do discurso: a paródia” in Nicolai Gógol, O nariz \& A terrível vingança. São Paulo: Edusp, 1990, p. 137. A citação de Haroldo de Campos que encontramos no texto de Cavaliere está em em Oswald de Andrade - trechos escolhidos. Rio de Janeiro: Agir, 1967.

${ }^{77}$ Mikhail Bakhtin, Problemas da poética de Dostoiévski, trad. Paulo Bezerra. Rio de Janeiro: Forense-Universitária, 1981.

${ }^{78}$ L. Hutcheon, op. cit., p. 16.
} 
Já "O convidado de pedra", uma das peças de Púchkin que compõem as Pequenas tragédias, refaz somente o clássico final do mito Dom Juan. Os personagens centrais presentes na obra do poeta russo já estavam em Dom Giovanni, inclusive a epígrafe da pequena tragédia é citação de uma fala de Leporello.

O Dom Juan de Púchkin, de passagem por Madri (como estava de passagem por Cesena o conquistador de Tsvetáieva), envolve-se com duas mulheres (como acontece em Uma aventura): Laura e Dona Anna. Anna é a filha do Comendador, que será morto por Dom Juan e que voltará como estátua. Ou, na peça de Púchkin, "convidado de pedra".

Ainda segundo Linda Hutcheon, é intrínseco à paródia a imitação caracterizada pela inversão irônica, marcando sempre a diferença em vez da semelhança, e o riso não precisa aparecer para que chamemos de paródia o recurso estilístico de imitação baseada em ironia. A inversão irônica é facilmente percebida em Uma aventura ao nos depararmos com o conquistador transformado em alvo da conquista.

Um Casanova amável, todavia, não é exclusividade do gênio de Tsvetáieva. Apesar dos demais conquistadores, conhecidos provavelmente por ela (já que era assumidamente leitora de Púchkin e facinada pela arte de Mozart), como Dom Giovanni, existirem quase que inteiramente para seduzir e ludibriar mulheres, um autor ousara inverter o mito. Um Dom Juan perseguido por mulheres é o que nos apresenta Lord Byron em sua obra Dom Juan, como está dito no começo do épico, busca um herói diferente ${ }^{79}$.

Dom Juan de Byron é um dos maiores poemas do romantismo inglês, segundo Watt $^{80}$, e chegou a ser considerado por muitos como uma obra de infinita genialidade, o que reflete em sucesso editorial até os dias de hoje, especialmente em língua inglesa. A base de sua criação é a inversão básica do enredo, transformando o Dom Juan em um sedutor passivo, e como tal, seduzido por várias mulheres. Chamar este personagem de Dom Juan é claramente uma opção irônica, uma vez que o mito já era amplamente difundido em 1818, quando o autor

\footnotetext{
${ }^{79}$ BYRON, L. Dom Juan. Londres: Penguin Classics, 2004.

${ }^{80}$ I. Watt, op. cit., p. 214.
} 
começou a obra ${ }^{81}$. O Dom Juan do poeta inglês é diferente: tem um pequeno número de casos amorosos, sendo o último deles com a imperatriz russa Catarina, a Grande, a cujos desejos sexuais ele se rende depois de se submeter a uma série de provas exigidas pela importante amante. Desses pequenos casos, apenas um envolve verdadeiros e mútuos sentimentos de amor, que é o relacionamento com Haydée; nos demais casos, ele é apenas atacado pelas mulheres. Não temos em Byron um personagem quase ausente em Tsvetáieva: o criado cômico, presente nas demais representações do mito do sedutor. Em Uma aventura o Duque, companheiro de aventuras de Casanova, tem uma aparição pouco relevante no final da peça, pouco decisivo para o enredo se comparado com o Leporello de Mozart. Para Hutcheon, o Dom Juan de Byron é um perfeito exemplo do que ela formula teoricamente como paródia e, portanto, acreditamos que Uma aventura também seja.

Das várias funções da paródia, Hutcheon menciona seu efeito para ressacralizar ou para dessacralizar um modelo já existente ${ }^{82}$. Uma vez que a paródia tem o efeito ressacralizador, ou seja, trazer novamente ao patamar do sagrado aquilo que fora esquecido ou desprezado, os procedimentos de Marina Tsvetáieva para a construção de Uma aventura podem ser apreendidos por meio dessa conceituação. Ao lançar mão de um personagem devasso ironizado, transformado em romântico e tornando-o não uma representação da promiscuidade, mas da vulnerabilidade do ser humano, um representante da paixão profunda, a poeta parece ressacralizá-lo por meio de um profundo dialogismo cultural, inserindo-o no tempo-espaço da nova Rússia que tomava corpo em 1918. O texto constitui, afinal, como disse Marina Tsvetáieva, conforme já citamos e como sugeriram nossas reflexões, uma ode ao amor. E, por seus procedimentos estilísticos, promoveu um elogio ao relacionamento amoroso, inspiração fundamental tanto para a criação de toda a poética, bem como motivação para a vida pessoal de Marina Tsvetáieva.

Os seus procedimentos estilísticos e dramáticos renovam, assim, a defesa de um estilo de vida e de um estilo de arte indissociáveis. O teatro de Tsvetáieva, em

\footnotetext{
${ }^{81}$ A primeira aparição do mito a que Watt faz referencia data de 1616 e é El burlador de Sevilla $y$ el convidado de piedra, de Tirso de Molina (nascido Gabriel Téllez (1581?-1648). Cf., para maiores informações, o capítulo “O burlador e Dom Juan” de I. Watt, op. cit., p. 100-27).

${ }^{82}$ L. Hutcheon, op. cit., p. 26.
} 
especial o ciclo a que Uma aventura pertence, Romantika, constitui, certamente, uma obra de resistência e de resiliência, de autoafirmação e autopreservação: a vocalização de uma visão de mundo, refletida na vida e na arte de sua autora. 
PARTE II

Uma aventura

Tradução 


\section{Nota à tradução}

Traduzir a lírica de Marina Tsvetáieva é um desafio para quem se aventura por essa seara. O texto dramático escrito pela poeta não é diferente, trata-se de uma escrita não linear que apresenta frases fracionadas, um árduo trabalho para o tradutor, inclusive na compreensão do texto, que se apresenta de forma tão única. O estilo da peça aqui apresentada é difícil de ser recuperado em língua portuguesa. Tentamos superar a dificuldade através da recriação poética, mas consciente de que a tradução proposta não se considera finalizada ou definitiva. É, sim, um caminho tradutório ainda inconcluso. Mesmo sabendo que não alcançamos a maestria rítmica e de rimas de Tsvetáieva, acreditamos que a presente tradução, como uma possível aproximação poética que preza, antes de tudo, pela clareza do enredo, nos ajuda a exemplificar o que a poeta elaborou quanto à sua dramaturgia, nosso principal objetivo nesse trabalho.

O texto original que foi base para a nossa tradução está presente no volume Избранные произведения, publicado em 1984, além da versão virtual presente no site <www.tsvetayeva.com>. No auxílio para cotejo, pudemos contar com a tradução do russo para o francês de Hélene Henry para o ciclo Romantika. E com as indispensáveis leituras feitas pelas colegas russas, especialmente Yulia Mikaelyan, que nos ajudaram, verso a verso, a compreender as referências, o ritmo, as escolhas sintáticas e semânticas de Marina Tsvetáieva.

Para chegar à versão aqui apresentada, também pudemos contar com a leitura de Livia Azevedo Lima, especialista em dramaturgia. As incontáveis interveções, sempre elucidativas e criativas, da orientadora Profa. Arlete Cavaliere foram impressindíveis para que o texto se aproximasse um pouco da fluência e do lirísmo que podemos encontrar na maestria do texto russo de Marina Tsvetáieva. 


\section{Uma aventura peça em cinco atos}

Vous oublierez aussi Henrietta

Vós esquecerás também de Henriqueta ${ }^{83}$

${ }^{83}$ No original, a epígrafe aparece em francês e, em seguida, em russo: Вы позабудете и Генриэтту. 


\section{Lista de personagens}

Giacomo Casanova - no primeiro ato, 23 anos; no último, 36. Carvão pontiagudo. Henri-Henrietta - 20 anos, luz da lua.

Capitão - quase 50 anos, velho militar.

Menina - 17 anos. Pura juventude e pura Itália.

Duque - da mesma idade de Casanova. É seu servo e companheiro de combate.

Um Casanova exagerado.

Corcunda - como todos os corcundas.

Violoncelista - 18 anos, uma videira.

Pedant - encantadora ruína.

Proprietária da loja de roupas - italiana, uns 40 anos, faladeira.

1a funcionária e 2a funcionária - meninas.

Embaixador francês, Embaixador espanhol, 1o espanhol e 2o espanhol, 1o francês e 20 francês - marionetes.

Tempo e local da ação:

1o ato: Quarto de hotel em Cesena, 1748.

2o ato: Mesmo quarto de hotel, 1748.

3o ato: Vila no interior de Parma, 1748.

4o ato: Quarto do Hotel das Balanças, em outra cidade italiana, 1748.

5o ato: Mesmo quarto de hotel, treze anos depois.

Horário dos encontros: tarde e noite.

Minhas fontes de pesquisa: Tomo IV de Memórias de Casanova. 


\section{Primeiro Ato}

\section{Uma gota de óleo ${ }^{84}$}

Noite. Casanova, largado, dorme no sofá, próximo do mapa das estrelas. Dá para perceber que ele caiu no sono sem querer. No chão, vê-se livros jogados. As chamas das três velas do candelabro queimaram até o final. O começo da cena é no escuro total.

Uma batida e uma voz através da porta.

- - - Permiti-me subir.

- - - Vós estais está ocupado? Dormis?

Por acaso estais sozinho? Que silêncio de túmulo!

Viva o exemplo do gato e do ladrão!

(Jovem hussardo, com uma lamparina, à porta)

Está claro como na adega! - Lamparina, ilumine

Como uma tocha ao vento.

Casanova (enquanto dormia)

Javotte, és tu?

Comprei-te pulseiras!

\section{Hussardo}

Deve ser delírio.

\section{Casanova (ainda dormindo)}

Mas se o conde te visitar mais uma vez...

\footnotetext{
${ }^{84}$ Referência à história mitológica de Cupido e Psiquê, que Tsvetáieva também explora em vários de seus poemas curtos. Segundo a mitologia, Psiquê, humana, é proibida de ver seu marido, Cupido. Entretanto, durante uma noite de sono de Cupido, Psiquê ascende uma lamparina, aproxima-a do rosto do amado e vê a face maravilhosa de Cupido. Uma gota de óleo, porém, cai no braço do deus e o desperta, colocando um fim, temporário, na relação dos dois. É neste ato que se encontram pela primeira vez Casanova e Henrietta.
} 
Queres saber? Que o Diabo te carregue.

\section{Hussardo}

Que Deus me proteja!

(examina os livros espalhados por todos os lados)

O que estamos lendo? Dante. Ariosto.

"O significado dos astros." "Os sete companheiros do esqueleto"

Asmodeus tinha ou não rabo...?

Casanova (do mesmo jeito)

Então darei as pulseiras à Rosina!

Hussardo (à escrivaninha)

Uma pena afiada, um carimbo, uma balança...

Cartas e cartas! O cesto cheio de papéis! Uma festança.

Oh! Um sapatinho de mulher! Como há de ser

Como num único sapato o caminho percorrer?...

\section{Casanova (igual)}

Rosina!

\section{Hussardo}

Dois nomes de mulher em cinco

Segundos - e continua procurando.

Com certeza, dorme tristonho

E só no tal mapa tem consolo!

(Inclina a lamparina para o rosto do dorminhoco)

Alma e futilidade juntos!

De quantas Evas inocentes ele tem sido a serpente,

De quantas Ariadnis ${ }^{85}$, o Teseu?!

85 Ariadna é a personagem-título de outra peça de Tsvetáieva, como explicamos no primeiro capítulo desta dissertação, além de ser mais uma referência à mitologia clássica presente em Uma 
- Oh, uma gota de óleo! Oh, é meu fim!

Casanova (saltando na escuridão)

Quem está aí?

Le-duque? Socorro! Sbirri ${ }^{86}$ ! Morte! Rosina!

(Confusão)

Hussardo (acendendo a lamparina)

E disse Deus: faça luz!

Nem polícia, nem Rosina,

Só tremula a lamparina.

Eu, o vizinho Hussardo

Das farras vosso aliado.

\section{Casanova}

Eu dormi e estou sonhando?

Como chegastes até aqui?

\section{Hussardo}

Entrei pela porta.

Mas se aqui não se faz assim

Pela janela posso sair.

\section{Casanova}

Le-duque!

\section{Hussardo}

Não se erguerá para ajudar

Vosso Leporello ${ }^{87}$ - E porque:

aventura. "Serpente", referência ao mitológico casal Adão e Eva, é um dos poucos momentos em que a cristandade é trazida pelo texto de Tsvetáieva.

${ }^{86}$ No original cбuppbı. Sbirro, em italiano, significa guarda, policial que serve à Inquisição. 
Nessa noite, não descansará

Do senhor o servo singelo.

\section{Casanova}

Sois ladrão?

\section{Hussardo}

Um pouco.

\section{Casanova}

Estranho. A corrente está intacta

E o elo também... Não, ladrão não sois... Quem dera?

Sois marido de alguém! - Quimera! Bom demais para marido!

Então, senhor, o que precisais?

Que loucura vós atrais?

Hussardo (confiante, sentando-se no braço da cadeira)

Possuo uma estranha molestia

A insônia é minha tragédia.

\section{Casanova}

Ah, já conversamos demais, basta!

Ide dormir, curar a bebedeira.

Hussardo (com firmeza)

Prefiro o túmulo à cama!

\section{Casanova}

E na nuca, colocai uma compressa.

Hussardo (melódico)

Oh, não se curarão

${ }^{87}$ Leporello é o servo de Don Giovanne na ópera de mesmo nome, de Mozart. 
Com afetuosa compressa

Este coração,

Esta cabeça.

Oh, sou mais insone do que a coruja!

Assim como vós,

Mestre da insônia!

\section{Casanova}

Então, não sois um marido?

\section{Hussardo}

Marido não sou.

\section{Casanova}

E não sois ladrão?

\section{Hussardo}

Não sou, não.

\section{Casanova}

E não sois credor?

\section{Hussardo}

Claro que não!

\section{Casanova}

Nem marido, nem ladrão e nem credor -

Por que, então, batestes aqui?

Pelo som das esporas e pelos cordões,

Sois Hussardo, sedutor das damas.

Falais como louco,

Rostinho de anjo. 


\section{Hussardo}

Mentira e verdade.

\section{Casanova}

Como é melodiosa

Vossa jovem voz.

Mas, afinal -

Por que estais aqui?

(Vê-se um raio de luz da lua)

\section{Hussardo}

Por que sobre o leito

Este raio de luz da lua a brilhar?

\section{Casanova}

Quem sois?

\section{Hussardo}

Sou um raio de luz lunar.

Todos os caminhos posso trilhar.

\section{Casanova}

Quem sois?

\section{Hussardo}

Como a lua é companheira da Terra -

De Casanova serei eterna companheiro.

Para todos, sou o hussardo Henri,

Nada valho.

\section{Casanova}

Ainda assim, minha criança, que diabos

Fazeis aqui? 


\section{Henri}

Uma aposta.

\section{Casanova}

Aposta?

Henri (colocando a mão no ombro de Casanova)

Casanova, olhai pela janela!

Como o mundo enlouquece sob a luz do luar!

Tudo vai passar, tudo se esquecerá... Nem tudo vai ficar:

Henri ou Henrietta? Ternura ou apostar?

\section{Casanova (compreendendo)}

Henri? - Henrietta?

(salta)

\section{Henri}

Deixai-me! Não me toqueis!

Casanova (fora de si)

Apostar ou carinho?

\section{Henri (sorrindo)}

Que insolência!

Pelo jogo ardente da dúvida Hussardos

E mulheres deixam-se levar.

(Entra o Capitão.)

\section{Capitão}

Fechei a porta pois faz frio. 
Perdão, senhor, ${ }^{88}$ por essa visita

em horário tão tardio, no meio da noite.

Os cavalheiros, nessa hora, descansam em seus leitos.

Isto, é certo, é sagrado.

Mas a culpa é desse jovem ardiloso.

A noite mal chega e esse preguiçoso,

Rápido e sagaz, foge do leito,

Do qual sou vizinho.

Não adianta procurar. Respostas não há.

De manhã, sempre a mesma resposta:

Onde esteve, sobrinho? - Na missa.

O que o senhor diria sobre isso?

\section{Casanova}

Tudo no mundo - apenas nomes!

Há quem fale astro e quem fale lua.

Henri, hoje. Amanhã, Henrietta.

\section{Capitão}

O que quer dizer?

\section{Casanova (fervendo)}

Senhor, por este hussardo,

Agora, estou louco.

A insônia não é par do sono.

Bem, em suma, para palavras não desperdiçar:

$\mathrm{Eu}$, Casanova, dinheiro ou sangue

Estou disposto a pagar

\footnotetext{
88 "Senhor", no original, cyдapb, é a forma de tratamento estabelecido entre Capitão e Casanova. Os verbos usados pelos personagens, em russo, estão conjugados na segunda pessoa do plural. $\mathrm{Na}$ tradução, escolhemos manter na terceira pessoa do singular, como é usual em português quando usamos o pronome "senhor".
} 


\section{Capitão}

Eu sou soldado e não negocio do amor alheio.

Os velhos húngaros -

Honram o amor e a juventude..$^{89}$

Mas derramar o sangue de estranhos,

Hoje, o coração - não vai deixar.

(Para Henrietta)

Está livre!

(Ele sai)

Henri (Apoiando a perna na janela)

Parece que a Lua se apagou

E no céu profundo mergulhou.

A pobre Lua esquecei

E da gota de óleo lembreis.

89 A tradução francesa de Uma aventura [Romantika. Paris: Gallimard, 1998] torna o trecho assinalado mais claro dos que são de fato os versos originais de Tsvetáieva. Em francês: Nous autres/ Vieux Hongrois, nous honorons/ jeunesse et amour. Já, no russo, Tsvetáieva não deixa claro se o Capitão se considera um "velho húngaro": Чтят любовь/ И юность - старые венгерцы. 


\section{Segundo Ato}

Na noite seguinte. No mesmo quarto. Henri - que trocou o uniforme de hussardo por encantadoras roupas masculinas da época - e Casanova conversam sentados em lados opostos do sofá.

Casanova (continuando o diálogo interminável)

Eu vos amo!

\section{Henri}

Que voz encantadora!

\section{Casanova}

E vós não me amais!

\section{Henri}

Nem tudo

é tão simples sob a luz da lua, Casanova!

São sete os degraus na escada do amor...

\section{Casanova}

Então já estou no oitavo!

\section{Henri}

E há centenas de milhares,

Centenas de milhares de verstas entre "sim" e "não".

\section{Casanova}

E ainda não vos beijei uma só vez.

\section{Henri}

Nem todos os caminhos levam à Roma. 


\section{Casanova (com receio)}

Não, Roma pode nos ser perigoso.

Vamos à Parma! $!^{90}$

Eu vos amo.

\section{Henri}

Belas palavras!

\section{Casanova}

Mas vós não me amais.

\section{Henri}

...e lábios...

\section{Casanova}

Um amor ardente, assim, nunca amei.

E nunca mais assim amarei.

Henri (profundamente sério)

Assim: nunca. Mas outras mil vezes: diferente.

Apaixonado - sim. Fortalecido - sim

Desconhecido - não.

\section{Casanova}

O que olhais?

\section{Henri}

Olhos encantadores!

Beijá-los, que encanto...

90 A sugestão de irem a Parma está presente na biografia de Casanova, já que ele teria acompanhado Henrietta à Parma, onde teriam se estabelecido por alguns meses como casal. Cf. capítulo 2 desta dissertação. 
(Casanova aproxima-se. Henri afasta-se, rindo)

Não, não - como a luz da lua: só quando adormecer.

Não se esqueça: nós somos aventureiros.

No começo o dinheiro, depois o amor.

Casanova (voltando à realidade)

Que dinheiro?

Henri (fingindo seriedade)

Dinheiro pelo amor. E é minha obrigação

Avisar e prevenir: não menos de dez sequins.

\section{Casanova}

Mil!

Henri

Pouco.

\section{Casanova}

Mais esse anel!

\section{Henri}

Pouco.

\section{Casanova}

Mil, a corrente e o anel.

\section{Henri}

Pouco.

\section{Casanova}

Maldita 
Derrota de ontem $!^{91}-\mathrm{E}$ as fivelas!

\section{Henri}

Pouco.

Casanova (em desespero)

E essa caixinha!

\section{Henri}

Pouco! pouco! pouco!

\section{Casanova}

$\mathrm{O}$ que exigireis?

Henri (encosta o dedo no peito de Casanova)

Esta alma -

para sempre, e esta

pistola turca - para um tiro mortal.

(Examinando a pistola)

É turca?

Casanova (como que sonhando)

Sim, sim.

\section{Henri}

Dás a mim? $?^{92}$

${ }^{91}$ No original, “Чертов/ вчерашний проигрыш!”. Apesar de não estar claro, é possível deduzir que Tsvetáieva faz referência às constantes apostas nos jogos de carta, hábito (ou vício) de Casanova testificado em suas memórias. Verificar I. Kelly, na bibliografia.

${ }^{92}$ As escolhas dos pronomes de tratamento usados entre as personagens variam de acordo com suas relações. A partir desta fala, Henri / Henrietta e Casanova começam a se tratar por $m b$, que em nossa tradução equivale à segunda pessoa do singular, $t u$, que em russo simboliza o tratamento usado entre pessoas mais intimas, um relacionamento menos formal. Essa alteração do uso do 


\section{Casanova (concordando)}

Dou.

\section{Henri (como uma criança)}

E não me tomarás?

\section{Casanova}

Não...

\section{Henri (gesticulando)}

Vamos, vamos, messere $!^{93}$

Depois, não choreis,

O preço é alto demais para tais bens!

Curvai.

(Casanova inclina a cabeça.)

Este primeiro beijo

$\mathrm{Na}$ insensata fronte, para que sejais bondoso e ciente.

Iremos, passo a passo, adiante:

Como ordenou o Senhor: antes dos olhos, a fronte...

\section{Casanova (furioso)}

Quando então nos lábios?

\section{Henri (sério)}

Escuta, meu amigo!

Deus criou seu mundo divino em uma semana.

Uma mulher é como cem mundos. Numa só alma unificada -

Como tornar-me mulher em um só dia?

pronome simboliza também uma alteração no relacionamento dos personagens, que deixa de ser formal para passar a ser afetuoso.

${ }^{93}$ No original, мессэре. Messere, em italiano, é a forma arcaica de signore. Mantivemos a expressão em itáliano, conforme o original russo, mas signore equivale a senhor, em português. 
Ontem era hussardo - usava esporas e espada,

Hoje - um anjo com laços de cetim,

Mas amanhã - talvez - como saber? Quem sabe?!

Casanova (cerrando os punhos)

Juraste me enlouquecer!

(Batem na porta. Casanova fora de si:)

Quem é?

\section{Voz atrás da porta}

Lojas de roupa Santa Croce..$^{94}$

Henri (erguendo-se nas pontas dos pés)

Beijastes a face - beijemos os olhos!

(Entra a Proprietária seguida por duas artesãs.)

Proprietária (empurrando as artesãs)

Eu primeiro! Todas ao mesmo tempo não dá.

Olá, signores. ${ }^{95}$

\section{Casanova}

Em boa hora!

A signora estava cansada de esperar.

\section{Proprietária}

Mas eu, eu mal consegui carregar!

Três boas moças para essa encomenda

${ }^{94}$ No original, "santa cruz" aparece em italiano, porém, em cirílico Санта-Кроче. Optamos por deixar em italiano.

${ }^{95}$ O mesmo se passa em "senhores". No original, aparece em italiano e cirílico (синьоры). Em nossa tradução, seguimos o critério adotado em casos anteriores e mantivémos em italiano. Em alguns casos, Tsvetáeiva utliza o termo russo сударь ои господ nos diálogos envolvendo a Proprietária e Casanova. Quando assim foi, traduzimos para o equivalente em português, "senhor". 
Três noites ficaram os olhos sem pregar.

Dorina ficou até suada,

E Janine teve soluços,

Mas fizeram o trabalho com miçangas

Como notas de uma sonata.

Onde está a signora?

Casanova (apontando para Henri)

Ei-la.

\section{Proprietária}

Onde?

\section{Casanova}

Ei-la.

\section{Proprietária}

Os senhores devem ter tido

Um jantar alegrinho, não?

\section{Casanova}

Estou the dizendo,

Eis a signora!

\section{Proprietária}

Juro por tudo que há de sagrado

Que signora não vejo nesse quarto...

Muito pelo contrário.

\section{Casanova}

Para por logo fim à discussão:

A signora, cansada da

Sem rigor moda feminina, 
Jogou no jardim a luvinha,

Deixou de ser a senhorita... ${ }^{96}$

Agora se fez signor.

\section{Proprietária}

Sim, claro - que inépcia!

(para as atersãs)

Vejam, mihas filhas, que peripécia!

(para Casanova)

Senhor, como pode ser? Loira era

A signora que vi. Esta aqui é morena.

$\mathrm{E}$ - oh! - mais gordinha...

E o rosto - uma lua redonda!

Jamais me confundiria.

Casanova (com um riso falso)

Confundiu-se por completo, costureira.

Proprietária (acalorada)

Como pode ser, senhor?

O senhor nos lábios a beijou,

E ainda de Rosina a chamou:

"Rosina, minha rainha".

Henri (pensando em voz alta)

O cetim para olhos escuros encomendado -

Combinará agora com os olhos claros.

A vida jurou: tudo se fará cinzas...

${ }^{96} \mathrm{O}$ verso "deixou de ser uma senhorita" não está no texto de Tsvetáieva, mas foi acrescido na tradução de modo que se reproduzisse o ritmo do verso russo, que nessa estrofe enfatiza as tônicas em $o$. Para isso, mantivemos na sequencia três versos de oito sílabas poéticas, com tônicas finais na vogal i. Em russo: “А чтобы спор покончить скоро, -/ Синьора, утомивши взоры/ Непостоянством женских мод,/ Кинула чепчик в огород/ И порешила быть -синьором!” 
(coloca a mão no ombro de Casanova)

Querido, zangado não estou contigo.

\section{Primeira artesã}

E nenhuma palavra de desagrado!

\section{Segunda artesã}

E nenhuma gotinha de ódio.

Proprietária (descarregando caixas de papelão)

Veja que mimos, signora!

Quatro vestidos, signora!

\section{Primeira artesã}

E ela não chora!

\section{Segunda artesã}

Nem se enfurece.

\section{Casanova}

Henrietta - Henri!

Henri (sobre os vestidos)

Um tem as cores da lua minguante,

O outro - as cores do alvorecer!

Proprietária (continuando)

Lenços! Mantilhas!

\section{Henri}

São magníficos vossos presentes.

Mas uma coisa esquecestes:

Uma capa - da cor do tempo. 
Assim, com grande golpes -

nossa vida prepara nosso peito...

\section{Proprietária}

Belo pensamento, senhora.

Agora vamos as medidas ajustar, senhora.

Henri (falando para o nada)

Uma capa - empoeirada e poderosa.

Uma capa - pobre e gloriosa.

Proprietária (segurando o pesado vestido)

Aqui apertamos, ali diminuímos,

Neste ponto alfinetamos, ali reduzimos...

(Henri, Proprietária e Artesãs saem)

\section{Casanova}

Mil trovões! Geniosa! Tenho razão!

Não é uma vendedora, e sim uma demônia. Mas Henri - é como aço!

Nem a sobrancelha moveu! Nem pestanejou - que coisa! - Louvado

Seja Deus nas alturas - pelo amor! - quem está aí?

\section{Voz atrás da porta}

É o capitão de ontem.

\section{Casanova}

Ah, vós? Entrais.

\section{Capitão (entrando)}

Eu queria ter, de amigo para amigo -, uma conversa sincera convosco

Sobre o que ontem ocorreu. Permitis, messere? 


\section{Casanova}

Sou todo ouvidos.

Capitão (encolerizando-se)

Essa criatura vos ama.

\section{Casanova}

Essa criatura é a minha noiva!

\section{Capitão (imperturbável)}

Talvez a mãe tenha morrido cedo

E de longe, balançou o seu berço

Sob o céu proceloso. É um obscuro começo.

Obediente como uma criança, gentil, inteligente O velho Horácio a ela dedicaria suas odes! -

Mas de repente colocou trajes masculinos,

Vagueia pelas janelas, como se fosse a própria lua,

Sóbria depois de beber, e sem vinho - ébria.

\section{Casanova (ameaçador)}

Poderíeis ser mais gentil, velhote?

\section{Capitão (imperturbável)}

Ora canta versos à honra de Platão.

Ora, chispa para a sela. Onde vai? É uma ordem!

Espero uma, duas horas. Chega voando.

\section{Casanova}

E então?

\section{Capitão}

Um duelo lutou

Com um dos favoritos da corte polonesa. 
Tudo por um comandante!

\section{Casanova}

Como em vossa mão parou este tesouro?

\section{Capitão}

$\mathrm{Na}$ época eu estava, há três semanas,

Em Civitavecchia ${ }^{97}$, no hotel...

(estala os dedos)

\section{Casanova}

Dane-se qual hotel!

\section{Capitão}

E eis que, de trança fininha,

Um hussardo vai pela escada e, atrás dele...

(Pausa. Suspiro de felicidade)

O outro hussardo.

Sois bom, eu não; tendes vinte anos, eu sou velho -

Jovem ou não - todos têm o direito de morrer!

Arrasado! Encantado! Como metal atraído

Para o ímã. Um ia à frente, e nosso Henri atrás dele.

Esvaneceu a fumaça de um charuto - mas outra fumaça no coração penetrou

Quando ela, cílios como flechas,

Em mim, como que por acaso, a capa de chuva encostou.

\section{Casanova}

E então...

\section{Capitão}

E então, foi assim: das duas janelas do meu quarto

Vejo tudo pela janela deles. Ele não é marido e nem noivo,

\footnotetext{
${ }^{97}$ Civitavecchia é um condado italiano da região do Lácio, província de Roma.
} 
Nem mesmo irmão - dele para nada ela tem precisão!

Sentados para jantar - mais parece um funeral!

Quietos, não comem! Os lábios fechados.

O outro vai deitar.

Eu, rude e estúpido -

Chamo meu servo: veja! - ele olha, queixo caído.

Chame-a para vir aqui!

\section{Casanova}

Que diabo!

\section{Capitão}

Por dez sequins.

\section{Casanova}

Ela foi?

\section{Capitão}

Foi. E fomos ao parque.

Eu contando moedas a ela.

Ela ri: pensa que não tenho

Meus sequins? - de supetão,

Joga a bolsa a meus pés.

\section{Casanova}

Uma deusa!

\section{Capitão}

Eu não sei até hoje,

Messere, que serpente a mordeu - mas é simples a conclusão:

$\mathrm{O}$ outro dormia. Como um casal de amigos,

A Cesena uma carruagem nos levou.

E não nos separamos desde então. 


\section{Casanova}

Então

Quem é ela? De onde veio?

\section{Capitão}

Do desconhecido.

Do nevoeiro. Do engano. Talvez, de um romance.

Ou de um protetor malevolente.

Ou de um marido violento; - poucas luas ela viveu.

Mas este século viveu loucamente.

\section{Henrietta (entrando)}

Permitam interromper...

(Casanova e Capitão levantam atônitos)

... senhores...

\section{Capitão}

Relâmpagos e escuridão!

Santa Madona - cavalo e esporas!

Ah! Sou um tolo. Ah! Sou um canalha!

\section{Proprietária}

Bem, que achais da senhora?

\section{Primeira artesã}

Uma doçura!

\section{Segunda artesã}

Um anjo!

\section{Primeira artesã}

Mãe de Deus! 


\section{Capitão}

Como pode! - onde repouso meus olhos?

Proprietária (com falsa modéstia)

Para uma primeira prova,

Não é tão mal, não?

Casanova (só agora acordando)

Das forças divinas é a fusão!

\section{Proprietária}

Juro, ninguém usa

Um vestido com tamanha elevação!

\section{Capitão}

Renuncio ao vinho e às cartas.

Proprietária (recebe uma bolsa de moedas de Casanova)

Que sequins barulhentos!

Agora é junho!

(a Casanova)

Deixe que março vos presenteie

Semelhante filha

(à Henrietta)

A vós - um filho semelhante.

(A Proprietária e as Artesãs fazem uma reverência e saem)

\section{Capitão (suspira)}

Eu também, caros amigos,

Suspirando me vou. 
Henrietta (distraída) ${ }^{98}$

Tão cedo?

\section{Casanova}

Por que a pressa?

\section{Capitão}

Fazer o quê? - negócio urgente.

(para Casanova)

Vossa juventude me agrada.

(para Henrietta)

Sou vosso admirador - sempre.

(sai)

Casanova (dando um anel à Henrietta)

Hoje um anel, amanhã uma pulseira

Henrietta (em sintonia)

Hoje loucura, amanhã - desapego.

\section{Casanova}

Veja - não escalarás as janelas de outros Casanovas.

\section{Henrietta}

Eu não sou mais um ladrão, e nem um gata -

Eu sou vossa escrava.

\section{Casanova}

Meu destino tu és!99 Fatal e triste felicidade!

\footnotetext{
${ }^{98}$ Em russo: светски, que, literalmente, pode ser traduzido como "leigo", "mundano" ou "secular". Optamos por "distraída" por acreditarmos que compõe melhor a cena, em português.

99 A partir desse ponto da peça, Casanova e Henrietta tratam-se por $m b$. Optamos por traduzir os diálogos usando a segunda pessoa do singular.
} 
(silêncio)

Henrietta?

\section{Henrietta}

Casanova?

\section{Casanova}

Esconde os olhos...

Não estás feliz?

\section{Henrietta}

Estou feliz - mas em silêncio.

Uma vez, em nosso castelo, a mulher do guarda florestal

Previu na borra do café...

\section{Casanova}

Em nosso castelo?

\section{Henrietta}

Eu me enganei... sem querer...

Não ouças!

\section{Casanova}

Henrietta, onde é o teu castelo?

Quem és tu?

\section{Henrietta}

Um mistério.

\section{Casanova}

Tu não me dirás? 


\section{Henrietta}

Um mistério,

Casanova! E a adivinhação no café -

foi só um estúpido grunhido sonolento das babás.

\section{Casanova}

Não acreditas, pensas talvez - que serei grosseiro,

Serei gentil, serei cuidadoso.

Era lobo, agora serei cordeiro.

Posso essa mecha de teu cabelo beijar?

Henrietta (fechando os olhos)

Nos lábios. 


\section{Terceiro Ato}

\section{Violoncelo}

Terraço de uma casa, numa vila em Parma. Noite. Degraus que levam para o jardim.

\section{Primeiro francês}

Festa muito estranha. Cavaleiros aos milhares,

Mas nossas damas...

(olha para Henrietta, que conversa com Pedant)

\section{Segundo francês}

Não pode ser que no céu

Existam duas luas...

\section{Primeiro francês}

Mas há estrelas, além da lua.

É encantadora e parecida de modo estranho

À luz da lua.

\section{Segundo francês}

E a algum encantado sonho.

\section{Primeiro francês}

As pessoas aqui não se conhecem.

\section{Segundo francês}

É claro,

Nosso anfitrião é excêntrico - e curvado -

E também está apaixonado.

Não pretende, de modo algum, ser notado,

Admiradores à porta de sua amada estão vetados. 


\section{Primeiro francês}

E aquele

Ao lado dela, seco e ardente e queimado como o carvão no hades,

Quem é ele?

\section{Segundo francês}

Que pergunta! É certo um amigo,

O marido não é, certo?

(analisando Casanova)

Parece que já

O vi em algum lugar... ah! Sim - estou certo!

Aquele que arruinou o banco, um tal de

Farucci ou Ferucci.

(saem conversando)

Corcunda (aproximando-se de Henrietta e de Pedant)

Criatura celestial, agrada-vos o vosso

Erudito interlocutor?

\section{Henrietta}

Interlocutor?

Como ousaria chamar com palavra tão imprópria

Este pilar de sabedoria notória

Diante de quem me ponho de joelhos?

\section{Pedant}

Se o próprio Cícero, realizasse

O retorno pelas águas do Lete, ${ }^{100}$

Sob este arco de madeira, belos discursos

Promulgasse,

Juro, o arco não refutaria um discurso com tal deleite. ${ }^{101}$

\footnotetext{
${ }^{100} \mathrm{Um}$ dos rios de Hades. Lete causa esquecimento àqueles que bebem ou mesmo encostam em suas águas.
} 


\section{Henrietta}

Encabulai-me.

Pedant (com uma saudação)

A mais cortês dentre todas as mulheres sob a lua

Ouvi Pedant-Cavaleiro:

Diante de tal figura encantadora, ficam tímidos

Não só Cícero, como a própria Vênus.

(sai)

\section{Corcunda}

E o que dizes desse jardim,

Embora do Cupido não seja refúgio,

(tudo por culpa da corcova), mas das nove irmãs

Imortais, das quais sois a décima...

\section{Henrietta}

Esse jardim obscureceu,

Para sempre aos meus olhos, o jardim de Versailles.

Corcunda (animadamente)

Conheceis Versailles?

Henrietta (friamente)

De certa forma, sim.

Conheci de passagem...

${ }^{101}$ Pedant, como o próprio nome indica, é o personagem que possui falas mais truncadas no original. Apesar de priorizarmos em nossa tradução a compreensão do texto, mantivemos inversões sintáticas e lançamos mão de um amplo leque lexical para dar conta da personalidade criada por Tsvetáieva. 


\section{Corcunda}

Lembro que a signora, em nosso

Encontro na ópera - a data

Em meu coração bem gravada -, revelou uma paixão por medalhas.

\section{Henrietta}

Sou apaixonada,

Por tudo que é eterno.

\section{Corcunda}

Eu vou me acalentar

Com a esperança de que meus Cellines ${ }^{102}$

Mereçam... - tudo culpa da corcova!

Não me lisonjeio com a suave esperança

De receber de vós: um sorriso.

Henrietta (apontando para Casanova)

Permitam-me

Convidar o cavaleiro...

Corcunda (sarcástico)

A predileção

Ainda é por ele?

Henrietta (com precisão)

Ele está unido a mim,

E eu, a ele. Venha, cavaleiro.

(Henrietta, Casanova e Corcunda saem)

\footnotetext{
${ }^{102}$ Benvenuto Cellini foi um pintor e escultor francês do Renascimento. Viveu entre 1500 e 1571 em Florença. Pendant, ao citá-lo, faz uma exibição de sua erudição, que é parte de um comportamento caricato que Tsvetáieva desenvolve como um dos traços do personagem.
} 


\section{Primeiro espanhol}

O anfitrião está apaixonado!

Segundo espanhol (insinuando com a mão à altura do corcunda)

Não é difícil

Perder a cabeça! Juro pela capa

E pela espada do hidalgo: ${ }^{103}$ exceto a espada,

Tudo - por um único olhar!

\section{Primeiro espanhol}

Trabalho em vão...

(O Embaixador espanhol e o Embaixador francês aproximam-se, conversando)

\section{Embaixador espanhol}

Oh! - sobre o que é a acalorada conversa??

\section{Embaixador francês}

De quem é o trabalho?

\section{Primeiro espanhol}

É belo e eterno

O trabalho do espanhol: capturar

O não capturável. Agora é isso.

\section{Embaixador espanhol}

Ah! Faleis da nossa diva estrangeira!

Mas por que tão sem esperança?

\section{Primeiro espanhol}

Don

\footnotetext{
${ }^{103}$ No original, гидальго. Optamos por usar a expressão espanhola, hidalgo, por acreditar que é proposital que palavras de língua espanhola estejam nas falas de personagens oriundos dea Espanha.
} 
Antônio, se em uma hora

A bela o peito não arfa

Quer dizer que está feliz e, quer dizer que

Não precisa mais nem de vós - nem de vós - nem de vós.

(a si mesmo)

Nem do vosso servo, nem de todo universo,

Nem mesmo do infante.

\section{Segundo espanhol}

Falem mais baixo!

Os corcundas são espertos e tudo ouvem.

(os dois espanhóis se afastam)

\section{Embaixador espanhol}

E quem é ela?

\section{Embaixador francês}

Certamente não é italiana.

Essa silhueta esbelta e seus olhos maravilhosos

São como a margem do lago, que seduz e reluz.

(com um sorriso)

Que importa a sua pátria?

Quando de todas as mais belas é: aquela espuma que deu forma à Vênus?

E quem é o seu Páris?

\section{Embaixador espanhol}

Algum trapaceiro,

Um mestre em agarrar a fortuna

Pela barra da capa.

E que olhos tem!

\section{Embaixador francês}

E que pele! 
Como se fora de porcelana.

Mas não sou um conhecedor de homens.

As beldades, sim. E elas bem nos conhecem.

(Aparece Henrietta de braços dados com o Corcunda)

\section{Embaixador espanhol}

Vênus junto de Vulcão.

\section{Embaixador francês}

Não, talvez Diana

Com o fauno cativo.

\section{Corcunda}

Devolvo

A oitava maravilha do mundo - nossa musa!

\section{Embaixador francês}

Eu troco oitava por primeira, amigo,

e - somos assim, os franceses -

Melhor "Dama do Coração" do que "Musa"

Henrietta (olhando para Casanova)

Sei também ser a Dama da Alma.

Embaixador francês

E não é a mesma coisa?

\section{Henrietta}

Chamarei o coração de ponteiro dos segundos;

E a alma de quadrante estrelar.

\section{Corcunda}

Divino! 


\section{Pedant}

Maravilhoso!

\section{Embaixador francês}

E acertado.

\section{Pedant}

Sois como Espinoza - para qualquer pergunta

Tem a resposta.

\section{Henrietta (risonha)}

O mês de setembro ${ }^{104}$

Deu-me um lar -

(olhando para o céu)

- O Hotel Balança.

Bem, meu relógio, queridos amigos,

Funciona graças ao relojoeiro Espinoza. ${ }^{105}$

(Do jardim, vêm as primeiras notas do minueto. Henrietta para Casanova)

Escute, Giacomo! O minueto!

Meu amigo e cavalheiro - a postos.

\section{Pedant}

Divinal, eu vos tecerei um soneto

Em que Espinoza rimará com Rosa.

(Dançam o minueto)

\footnotetext{
${ }^{104}$ Setembro é o mês do aniversário de Marina Tsvetáieva no antigo calendário (no atual: 8 de outubro).

${ }^{105}$ Baruch Espinoza (1632-1677) é um dos grandes nomes da filosofia moderna. Tsvetáieva, porém, traz à peça uma faceta não muito difundida do grande pensador: ele teria sido de fato relojoeiro em sua época.
} 


\section{Embaixador espanhol}

Nada é para mim um xale espanhol

Perante ela!

\section{Pedant}

Pela primeira vez o Pedant arrepende-se

De ter estudado as ciências

E não o minueto!

\section{Corcunda}

Maldita seja minha corcova!

\section{Casanova}

Henrietta!

\section{Embaixador francês}

Vós me levastes a Versailles!

(Pausa)

Humilde, acredito e espero,

Que ao se abanar com esse leque

Seu terno descanso será breve?

\section{Henrietta}

Que encantador ministro!

Vós me obedecereis?

\section{Embaixador francês}

Hoje e sempre.

\section{Henrietta}

Não leveis convosco este capricho

Para vossa lista negra:

Não quero mais dançar. 


\section{Embaixador francês}

Uma dança me deveis.

\section{Pedant}

Eu estou paralisado.

\section{Embaixador espanhol}

Não. Mesmo diante da Rosa das Rosas

Não esqueço que sou espanhol.

(sai)

\section{Henrietta}

Eu quero música.

\section{Corcunda}

O desejo da soberana é lei.

Para cá, Sandro magnífico!

(o belo Sandro, devagar e relutante, aproxima-se com seu violoncelo)

Terás a honra

E a felicidade

De ser ouvido por essa signora.

A signora deseja melodias.

\section{Belo Sandro}

Ah! A tempestade

Deve estar próxima. Estou num estranho

Nevoeiro.

\section{Embaixador francês}

Onde está a tempestade? Olhai para cima:

Todas as estrelas estão à vista

E se nenhuma avistar 
(olhando para Henrietta)

Olhai para baixo.

\section{Belo Sandro}

Parece que ouço

Algum retintim

Henrietta (simpática)

Vós não estais doente, sim?

\section{Belo Sandro}

Sim, adoeço. Não consigo tocar.

\section{Corcunda}

Músicos - pessoas estranhas!

Querem que imploremos por horas, anos, séculos...

Henrietta (olhando carinhosamente para Sandro)

Não se pode zangar com tais extravagâncias

Como mulheres: tocam como querem,

Quando querem, para quem querem...

(Para Sandro estendendo a mão)

Maestro,

Sois meu aliado.

Belo Sandro (inclinando-se)

Como o arco e a acorda.

Henrietta (aproximando-se do violoncelo)

Vamos ver se ainda somos amigos,

Violoncelo, alma da minha alma?

(ela senta e toca) 


\section{Alguém}

Estou dormindo?

\section{Outra voz}

Não, é um sonho que sonhamos.

Embaixador espanhol (apertando o coração)

Como uma faca!

Embaixador francês (acariciando o próprio peito)

Como o mel!

\section{Corcunda}

Como um espírito bom de luto

Vai embora para outro mundo...

Belo Sandro (pela primeira vez sentindo-se humano)

Lairi - aprendiz!

O que tocastes para nós?

Henrietta (a ele)

Algo meu

(olhando para Casanova)

Para mim

(o Corcunda um momento antes foi chamado pelo servo, aproxima-se de Henrietta e das pessoas em volta dela)

\section{Corcunda}

Perdão por interromper vossa graça...

Enviaram uma carta a vós - o mensageiro não diz -

Quem a enviou.

(todos saem) 


\section{Henrietta}

Onde está a carta?

(não a abrindo)

Oh, os sete carimbos!

(a Casanova)

Meu amor - devemos separar-nos. 


\section{Quarto ato}

\section{Hotel Balança}

Noite. Um amontoado de malas de viagem. Uma vela acesa. Na mesa, apoiando a cabeça sobre as mãos, está Casanova. Henrietta, vestida para viajar, nervosamente anda pela sala.

\section{Henrietta}

Que horas são?

\section{Casanova}

De hora em hora

essa mesma pergunta?

\section{Henrietta}

Justo esta noite meu relógio parou

Talvez para sempre,

Em lugar do tempo, a eternidade: o ponteiro revoou!

\section{Casanova}

Quebrastes?

\section{Henrietta}

Não, fostes tu, que ao dormir,

Deixaste-o cair.

\section{Casanova}

Eu não me lembro.

\section{Henrietta}

Lembras?

Tu ainda gritaste: o que é esse tinido?

E eu te disse rindo: o coração! 
(olhando o relógio)

Minguer Espinoza, sábio filósofo,

Mas que péssimo relojoeiro sois.

\section{Casanova}

Henrietta!

Logo nos separaremos. Senta-te aqui, querida,

Como - queres? - a despedida.

Henrietta (balançando a cabeça)

Não.

\section{Casanova}

Tu não queres?

\section{Henrietta}

Não importa o que queremos, meu amigo.

Enquanto viveres, sempre vais querer tudo,

Mas esta Vida agora é Morte.

Os soldados estão sempre frente à morte.

Ah! Não esqueças a pistola turca,

Teu presente.

\section{Casanova}

Meu pequeno menino! Henrietta!

Um último apelo?

\section{Henrietta}

Pois não.

\section{Casanova (como um criança)}

A noite é profunda, a carruagem é grande

E nós tão pequenos... 
Eu te juro, descerei

Na primeira curva!

Henrietta (à janela)

Nas casas,

Em todos os lugares, as luzinhas se apagam.

(vira-se a Casanova)

É inútil.

\section{Casanova}

Não tens alma!

\section{Henrietta}

Deves ter razão.

\section{Casanova}

Em suas veias corre o luar.

\section{Henrietta}

Pode ser que sim,

Pode ser que não.

\section{Casanova}

Diz-me - em despedida -

És anjo ou demônio?

\section{Henrietta}

É um segredo alheio.

Paremos com isso.

(olhando o relógio)

Pobre relógio!

E veja só que justamente

Na placa do hotel uma balança aparece. 
Onde o encontro eterno termina para sempre,

Como derrete a neve...

(colocando a mão no coração)

Tenho medo de que para sempre

Aqui morra a lei do equilíbrio!

(tira o anel do dedo e dá a Casanova)

Leva de volta.

\section{Casanova (arrogante)}

Nem cartas, nem aneis

Levarei de volta!

\section{Henrietta (como um eco)}

Nem juramentos, nem cartas

Tudo em vão.

\section{Casanova (fervendo)}

Ah! É assim?

\section{Henrietta (para si mesma)}

Para quê?

Não, querido, o adeus - é um adeus!

(escreve algo com o anel no vidro, a janela está aberta, o anel cai na noite)

Pronto, se foi.

\section{Casanova (estourando)}

Que belo amor!

Tudo por causa de malditos sete carimbos -

Ao diabo. Na noite, para sempre...

Que amor é esse, senão isto: uma aventura!

\section{Henrietta}

Vamos parar com isso. Deves 
Me prometer apenas isso. Se na vida ainda

Nos encontrarmos novamente, não poderás

Titubear. É teu dever. Compreende?

\section{Casanova (amargo)}

Compreendo.

Amor e dever, tudo isso também é novo...

Henrietta (e por um segundo, Henri)

Como um lobo branco - é um Casanova fiel!

(mudando o tom)

Só mais uma coisa: nunca e em lugar algum

Tente descobrir quem sou eu - ou me condenarão à morte.

E mais uma coisa: ama

Uma outra. Uma outra, não. Ama a todas. Loucuras -

Três eu fiz em minha curta vida.

$\mathrm{Tu}$ - és a terceira e última - e derradeira.

Que horas são?

\section{Casanova}

Então vais sozinha?

\section{Henrietta}

Sim, assim como eu cheguei.

\section{Casanova}

Não, isso não pode ser!

\section{Henrietta}

Tudo é possível sob a lua!

(luz da lua)

Olha, a lua

Será os lampiões acesos pelo caminho... 
(apaga a vela, inclina-se sobre o encosto da cadeira, coloca as mãos na cabeça de Casanova.)

Um dia, nas memórias de outrora,

Tu irás escrevê-las já grisalho,

Ridículo, esquecido, fora de moda, uma estranha

Sobrecasaca roxa, em algum lugar

Num castelo esquecido por Deus - em exílio -

Sob o uivo dos lobos - sob ventos tempestuosos - a duas velas...

Só, só, sozinho - depois de acabar com todo amor,

Casanova! Mas teus olhos,

Eu vejo teus olhos: os mesmos que em carvão

Tudo transformam, os mesmos que, em pó e cinzas,

Transformaram a minha vida - eu vejo...

E as cartas brotam das mãos.

Cartas antigas - de mãos velhas,

Velha - senil, eis estas minhas...

(aperta as mãos dele às suas.)

Algum dia, nas memórias de outrora,

Alguma mulher como eu,

Como... mas, que horas são?

(Casanova silenciosamente mostra a ela seu relógio)

Já é tão tarde!

Eu juro que sonharei contigo!

(Coloca a pistola no cinto. À porta.)

Adeus! - solitária - sobre mim e sobre ti

A lua sem lar.

Casanova (a ela)

Diga-me.

Henrietta (balançando a cabeça)

Todos, sob a grande lua,

Jogamos no escuro. 
(Desaparece sob raio da luz da lua) 


\section{Quinto ato}

\section{Treze anos mais tarde}

Quarto do Hotel Balança, onde despediram-se Henrietta e Casanova. Casanova com sua milésima primeira namorada, entram. Um turbilhão de alegria.

\section{Menina}

Morais aqui?

\section{Casanova}

Hoje sim,

Mas amanhã...

\section{Menina}

Que gosto de conde tendes!

Santo Jesus! Sofá, cômoda, e lustre...

Tudo como se fostes ilustre!

E o chão é todo coberto por tapetes!

Tenho um só medo em minha mente:

Que isso não seja o tempo presente,

Temo acordar de repente.

\section{Casanova}

Onde está teu marido?

\section{Menina}

Dormem os meus maridos.

\section{Casanova}

E como te chamas?

\section{Menina}

Mimi. 
Quero jantar.

\section{Casanova}

Eu amo

Nas mulheres: o apetite!

\section{Menina}

Oh, eu até diria ao rei:

Quem alimentado não está,

Amar não poderá!

\section{Casanova}

Assim é com as crianças:

Dar de comer - e nanar!

\section{Menina}

Sim, sim, primeiro me alimente,

Depois pode abraçar!

\section{Casanova}

O que vamos comer?

\section{Menina}

Qualquer coisa!

Vamos, já que convidas!

E até a louça hei de jantar!

A colher e a faca -

Para o bolso, só para lembrar!

Casanova (divertindo-se)

E gansos

No bolso, para lembrar? 


\section{Menina}

Tudo no bolso!

Casanova (com um suspiro cômico)

Bem, folhearemos este

Romance gastronômico!

Beijas assim como comes?

\section{Menina}

Beijo assim como como.

Bebo assim como beijo - e canto,

Assim como bebo!

\section{Casanova}

Encarnação do Éden!

Le-duque! Não me ouve! Velho truque!

Preguiçoso, Le-duque! Insolente! Le-duque!

Le-duque (colocando a cabeça através da porta)

$\mathrm{O}$ que foi?

\section{Casanova}

O que foi, seu malandro,

Não te atrevas a ficar sonhando!

Apressa-te ao dono do hotel,

diz - logo, seu parvo -

que venha aqui vinho farto

E comida de todos os lugares da Terra,

E se não, diga que o conde...!

\section{Le-duque}

Bom conde! 


\section{Casanova}

Maldito temperamento!

\section{Le-duque}

Tão conde como eu!

\section{Casanova (com raiva)}

Vou te matar!!!

(friamente)

E o que sobrar, vai na sua

Boca cair, glutão!

\section{Le-duque}

Ficará aqui!

\section{Casanova}

Filho do cão!

\section{Le-duque}

Tal, messere, patrão

Tal o servo

\section{Casanova}

Insolente, calado!

\section{Le-duque (inflamado)}

Se sou filho do diabo - dele és o pai!

Por obra vossa, todo o mundo

Tem chifres, messere

Casanova (com um meio sorriso)

Maldito palhaço!

Fora!!! 


\section{Le-duque}

Londres, Roma, Paris - onde colocardes

O vosso olhar - em toda Europa

Estão os vossos diabinhos.

(Casanova arremessa nele o tinteiro, mas ele desvia e foge)

\section{Casanova (em seguida)}

Tolo!

(para a Menina)

Suspirou como em um sonho...

Entristeceste ou cansaste de ouvir?

\section{Menina}

Penso só no que no jantar vou pedir

E em quanto dinheiro podeis repartir.

(pensativa)

As baratas têm bigodes horríveis...

Vou para casa - um pote vazio e uma vassoura velha...

\section{Casanova}

E o que tu gostarias de ter?

\section{Menina}

Uma casa. Um relógio.

Um lacaio de ouro e muito, mu-uito dinheiro.

\section{Casanova}

Para que precisas de tanto dinheiro?

\section{Menina}

Para quê?

Eu não era nada, tudo serei. 
(sentenciosa)

Como a flor precisa de água,

Assim, dinheiro é preciso para viver.

Pelo menos para verter,

De manhã, não um pouco de creme no café

Mas em um monte de creme o café.

(sacudindo a sua saia)

Para ao diabo remeter esses trapos.

Para me mover em meu próprio carro.

Casanova (em volta dela)

Encantadores pezinhos!

Encantadores olhinhos.

\section{Menina}

Admiradores - como uma ninhada.

Um oferece a comida, o outro o licor...

(batendo palmas)

Para a beleza - o amor,

E para calvície - a risada!

\section{Casanova}

A própria sabedoria!

Menina

Bem que eu poderia.

\section{Casanova}

Quantos anos tens?

Menina

Dezessete.

Oxalá tragam logo o jantar! 


\section{Casanova}

E depois nanar.

\section{Menina}

Minha cama seria azul,

não - escarlate. E na cabeceira - o Cupido.

E de covinhas em toda parte e gordinho, gordinho.

\section{Casanova}

Pareces ainda brincar de boneca?

\section{Menina (ofendida)}

Nunca!

\section{Casanova}

Admite, quase nunca...

\section{Menina}

Quando eu era jovenzinha,

Eu brinquei de mamãe e filhinha.

\section{Casanova}

Queres cuidar de verdade de uma bonequinha?

\section{Menina}

Assim como vós - tudo quero -

Não, não quero. - Ridículo! - Vai coachar

Como um sapo!... não, pecado!

\section{Casanova}

O que é pecado?!

O destino de todas as moças é pecar e chorar, 
E chorar e pecar, e de novo chorar,

E depois as casulas ${ }^{106}$ da igreja bordar.

\section{Menina}

Eu vou chamá-la: meu Amor,

E no batismo seu nome será Liza.

(acelerando o ritmo da fala)

e sobre a cama, com seda rosa bordada,

muitas borlas, o baldaquirno a deixa enfeitada

E nele dormiria isolada; e sinto pavor

Quando roncam e faz calor,

E a dona vem me saudar, eu -

Veja - só!: uma cusparada nos olhos!

(cuspindo)

Assim, assim, assim lançada na testa dela

Uma moeda de ouro. Não uma, milhares!

E toma, toma, toma por ter-me

Deixado gelada no porão. - Demora a nossa refeição?

De qualquer forma, o tempo passa em vão,

Posso vos cantar uma canção.

Quereis?

\section{Casanova}

Cante neste momento!

\section{Menina}

Não sois avarento?

Dar-me-eis algum dinheiro?

(Casanova, rindo-se, esconde dela no peitilho algumas moedas. Ela dá um ganido e canta)

A paixão bate como martelo

A ternura serra a serra.

${ }^{106}$ Casula é a vestimenta que o sacerdote usa sobre a alva e a estola ao rezar a missa. 
Era alegre o ouro amarelo

Vira cinza e seca.

É melhor - enquanto não perde o colorido

Os olhos marejados.

Querido, passeia com as donzelas,

Por entre rosas, como ordenou a Providência!

Lá estão os jardineiros no jardim,

E a rosa está sozinha, enfim!

Por entre a trilha dos amantes,

A lua vai me guiar adiante...

(interrompe)

A canção é curta, mas nos conduz à Roma!

A música é bonita?

\section{Casanova}

Contemplei tua boca rosada,

E tua pequena nuca...

\section{Menina (ofendida)}

Que estranho o que olhais enquanto estou a cantar!

(olhando para fora da janela)

A lua!

\section{Casanova}

A Santa Mãe de todas as traições.

Menina (sonhadora)

Ela é azul

(fixando o olhar na janela, lê)

"Esquecerás"- e o que mais? - “ Henr, Henr...

esquecerás também Henrietta”? 
Casanova (aproximando-se dela)

O que lês?

\section{Menina}

O que está escrito no vidro

Aqui, à esquerda, riscado com diamante -

“Também Henrietta”.

\section{Casanova}

Estou cego?!

Hotel Balança - relógios - salvem a minha mente!

Gravado na janela com diamante - o anel - o anel!!!

Treze anos atrás!!! - Ei, cavalos, rápido!

(quebra o vidro com um soco. Voam cacos. Começa a ventar.)

\section{Menina}

Que rosto assustador!

Por que gritais tanto?

\section{Casanova}

O que fazeis? Quem és? Fora, miserável, suma!

(para a janela)

Meu amor! Meu menino-lua!

\section{Menina}

Só me cabe dizer: amém.

E então seguir em frente,

Antes que me mateis.

Casanova (sem entender)

Por que vieste? 
Menina (recuando)

Vós me chamastes, o jantar prometestes...

\section{Casanova}

O quê! Jantar? - Além desse vidro,

Eu não preciso de nada, ouviu?

(não há vidro, bate com a mão no vazio.)

Menina (lamentando)

Agora vou embora... primeiro criam a desgraça,

Depois - uh, uh - a trapaça...

\section{Casanova}

Treze anos, Henri, que inferno!

Minha metade platônica!

Quem está chorando? Sob a luz do luar

Aparecerás como um sonho, um sonho. E Deus será

O juiz.

\section{Menina}

Compreendo: sois como os qualquer um

E não terá jantar algum.

Adeus!

Casanova (andando)

Estás indo?

\section{Menina}

Estou.

Eu vos odeio!

\section{Casanova}

Ah, como estás com raiva! 


\section{Menina}

Vos deixo com a senhora

Lua - entenda-vos com ela.

Beija-a.

\section{Casanova}

Bichinho feroz.

\section{Menina}

Não se atreva a olhar para mim!

Casanova (divertindo-se um pouco)

Diabinha!

Quero, e olho.

\section{Menina}

Em nada adiantará.

\section{Casanova}

Como envelhecer sem menininhas assim?

\section{Menina}

Eu queria tanto vos amar!

\section{Casanova}

Ora, ora! Ainda quererás!

\section{Menina}

Por que enlouquecestes de repente?

Casanova (batendo em seus joelhos)

Sente-se aqui. 
Menina (já nos joelhos)

Não olharás ${ }^{107}$ mais para a lua? - E para essas letras?

O que são essas letras? - não, para a janela

Não te atrevas olhar! - minha alma está atormentada!

(vira para si a cabeça dele com as mãos)

O que essas letras significam?

\section{Casanova}

Bem,

Apenas isso - uma aventura.

\section{Menina}

Amorosa?

\section{Casanova}

Não, não.

\section{Menina}

Ah! Sim, sim!

Conheço pessoas assim - a porta está trancada?

Jantar não quero mais.

(salta dos joelhos de Casanova para junto da estátua da Madona)

Um xale, bem aqui.

Para não deixar a Mãe de Deus tão chateada.

Fim

${ }^{107}$ A partir desse momento, a Menina começa a tratar Casanova não mais pelo respeitoso pronome bы (vós), mas como $m b l$, que traduzimos para a segunda pessoa do singular. 
Приключение

В пяти картинах 


\title{
Приключение
}

\author{
Vous oublierez aussi Henrietta... \\ Вы позабудете и Генриэтту \\ Casanova. Memoires.
}

\section{ЛИЦА}

ДЖАКОМО КАЗАНОВА, в первой картине 23 года, в последней

36 лет, острый угол и уголь.

АНРИ - ГЕНРИЭТТА, 20 лет, лунныЙ лед.

КАПИТАН, под пятьдесят, вояка.

ДЕВЧОНКА, 17 лет, вся молодость и вся Италия.

ЛЕ - ДЮК, слуга, ровесник и сподвижник Казаковы, преувеличенный

Казанова.

ГОРБУН, как все горбуны.

ВИОЛОНЧЕЛИСТ, 18 лет, лоза.

ПЕДАНТ, очаровательная развалина.

\section{марионетки}

ПОСОЛ ФРАНЦУЗСКИЙ, ПОСОЛ ИСПАНСКИЙ,

1-Й ИСПАНЕЦ, 2-Й ИСПАНЕЦ, 1-Й ФРАНЦУЗ,

2-Й ФРАНЦУЗ

ХОЗЯЙКА МОДНОЙ ЛАВКИ, сорокалетняя итальянская

скороговорка.

1-я МАСТЕРИЦА, 2-я МАСТЕРИЦА - ДЕВочки

\section{Время и место встреч}

I картина - комната гостиницы в Чезене

II картина - та же комната гостиницы 
III картина - загородная вилла в Парме

IV картина - комната гостиницы "Весы" в другом итальянском городе

V картина - та же комната гостиницы, 13 лет спустя - 1784 год

Час встреч: вечер и ночь.

Источники мои - IV том "Мемуаров" Казановы. 


\section{КАРТИНА ПЕРВАЯ}

\section{КАПЛЯ МАСЛА}

Ночь. Казанова, буйно разметавшись, спит на диване, под картой звездного неба.

Видно, что заснул случайно. На полу валяются книги.

Свечи в огромном трехсвечнике догорели. Начало картины в полной тьме.

Стук и голос за дверью

- Позвольте мне взойти!

- Вы заняты? Вы спите?

Вы, может, не одни?- Молчит, как гроб!

Да здравствует пример воров и кошек!

(На пороге молодой г у с а р с ночником.)

$<\Gamma$ У C A P $>$

Светло, как в погребе! - Ночник, свети,

Как факел на ветру!

К А 3 А Н О В А (во сне)

Жавотта, ты?

Браслеты я купил!

Г У C A P

Должно быть, бредит.

К А 3 А Н О В А (так же)

Но если граф к тебе еще придет...

А впрочем - черт с тобой!

\section{Г У C A P}

И Бог - со мной!

(Рассматривает разбросанные всюду книги.)

Что мы читаем?- Данте.- Ариост. 
"Значенье звезд".- "Семь спутников скелета".

Был или нет - у Асмодея - хвост...

К А 3 А Н О В А (так же)

Тогда Розине подарю браслеты!

Г У С А Р (у письменного стола)

Перо очинено... Весы... Печать...

А писем, писем! Полная корзина!

А, женский башмачок! Хотел бы знать,

Как в башмачке одном дошла...

К А 3 А Н О В А (так же)

Розина!

Г У C A P

Два женских имени за пять

Секунд - и все чего-то шарит!

Не весело, должно быть, спать

С одною картой полушарий!

(Наклоняет светильник к самому лицу спящего.)

Души и ветрености смесь!

Над скольких Ев невинных - змеем,

Над скольких Ариадн - стою - Тезеем?!

-Ох, масло капнуло! Ох, я пропал!

К А 3 А Н О В А (вскакивая в темноте)

Кто здесь?

Ле-Дюк! На помощь! Сбирры! Смерть! Розина!

Суматоха.

Г У С А Р (зажигая светильник)

И Бог сказал: Да будет свет! 
Ни сбирров, ни Розины нет, -

А просто нашалил светильник.

И перед вами - ваш сосед:

Гусар и бравый собутыльник.

K A 3 A H O B A

Я, кажется, заснул и вижу сои?

Как вы сюда попали?

Г У C A P

Прямо в двери.

Но если здесь у вас заведено

Не в дверь ходить - могу уйти в окно.

K A 3 A H O B A

Ле-Дюк!

Г У С A P

Не встанет вам помочь

Ваш Лепорелло. - А причина

Сему: не спит в такую ночь

Слуга такого господина.

K A 3 A H O B A

Вы вор?

Г У C A P

Немножко.

K A 3 A H O B A

Странно, цепь цела

И перстень пел... Нет, вы не вор,- вы хуже:

Вы чей-то муж! - Нет, хороши для мужа! 
Скажите же мне, сударь, что вам нужно?

Какая дурь сюда вас привела?

\section{Г У C A P}

(садясь на ручку кресла, доверчиво)

Я странным недугом недужен:

Моя болезнь - бессонные дела.

K A 3 A H O B A

Ну, побеседовали,- баста!

Идите просыпайте хмель!

Г У C A P

(твердо)

Скорей в могилу, чем в постель!

K A 3 A H O B A

И на затылок наложите пластырь.

Г У C A P

(певуче)

Ах, не залечит

Ласковый пластырь

Этого сердца,

Сей головы!

Ах, я бессонней самой совы!

Такой же, как вы,

Бессонных дел мастер!

K A 3 A H O B A

Так вы не муж?

$\Gamma$ У C A P 
Не муж.

K A 3 A H O B A

Не вор?

Г У C A P

Не вор.

K A 3 A H O B A

И вы не кредитор?

$\Gamma$ У C A P

Едва ли!

K A 3 A H O B A

Не муж, не вор, не кредитор,-

Зачем же вы сюда попали?

По звону шпор и по шнуровке

Гусар, очарованье дам.

Умалишенный - по речам,

И... ангелочек - по головке!

$\Gamma$ У C A P

И ложь, и правда...

K A 3 A H O B A

Как певуч

Ваш голос молодой... Но все же -

Зачем вы здесь?

Полоса луны.

Г У C A P 
Зачем на ложе

Нисходит этот лунный луч?

K A 3 A H O B A

Кто вы?

Г У C A P

Я - лунный луч. Вольна

Мне всякая дорога.

K A 3 A H O B A

Кто вы?!

Г У C A P

Как спутница Земли - Луна,

Я - вечный спутник Казановы.

А для людей - гусар Анри,

Грош, по рукам еще не стертый...

K A 3 A H O B A

Но все ж, дитя, какого черта

Сюда явились?

А Н Р И

- На пари!

K A 3 A H O B A

Пари?!

А Н Р И

(кладя ему руку на плечо)

Казанова, взгляните в окно!

Как в мире безумно от лунного света! 
Все минет, все канет... Не все ли равно:

Пари - или нежность. Анри - Генриэтта.

K A 3 A H O B A

(прозревая)

Анри? Генриэтта?

(Вскакивает.)

А Н Р И

Оставьте! Не тронь!

K A 3 A H O B A

(вне себя)

Пари - или нежность?

\section{А Н Р И}

(смеясь)

Какое бесстыдство!

Ни то, ни другое. В страшнейший огонь

Гусаров и женщин ведет - любопытство.

Входит К а п и т а н.

\section{К А ПИ Т А Н}

Прикрою дверь, а то сквозит.

Простите, сударь, за визит

В столь неурочный час полночный.

Всяк господин в своем дому.

Мне это свято, но всему

Виной - мальчишка сей порочный.

Чуть ночь настанет, быстр и бодр

Сей лодырь покидает одр

Свой, моему одру соседний. 
Ищу, свищу - ответа нет,

А поутру - один ответ:

- Где был, племянник? - У обедни!

Что, сударь, скажете на это?

K A 3 A H O B A

Все в мире - только имена!

Кто скажет: месяц, кто: луна...

Анри - сегодня, завтра - Генриэтта...

К А ПИ Т А Н

Что значит?..

K A 3 A H O B A

(вскипая)

То, что без ума

Я, сударь, от сего гусара,

Что сон бессоннице не пара,

Ну, словом, чтоб не тратить слов,

Я - Казанова, и готов

Платить казною или кровью.

К А ПИ Т А Н

Я - воин, и чужой любовью

Не промышляю. Чтят любовь

И юность - старые венгерцы.

А проливать чужую кровь

Сегодня мне мешает - сердце.

(Генриэтте)

- Свободна!

(Выходит.)

А Н Р И 
(занося ногу на подоконник)

Кажется, погасла

Луна, нырнула в глубину...

Забудьте бедную луну

И помните о капле масла! 


\section{КАРТИНА ВТОРАЯ \\ ДЕСЯТЬ ЦЕХИНОВ}

Следующий вечер. Та же комната. К а з а н о в а и А н р и, сменивший гусарский мундир на очаровательную мужскую одежду того времени, на разных концах дивана - беседуют.

K A 3 A H O B A

(продолжая нескончаемый диалог)

Я вас люблю!

\section{А Н Р И}

У вас прелестный голос!

K A 3 A H O B A

А вы меня не любите!

\section{А Н Р И}

He все

Так просто под луною, Казанова!

Семь ступеней у лестницы любовной...

K A 3 A H O B A

Я на восьмой тогда!

\section{А Н Р И}

И сотни тысяч,

И сотни тысяч верст меж "да" и "нет".

\section{K A 3 A H O B A}

Еще ни разу не поцеловали!

\section{А Н Р И}


Не все дороги в Рим ведут.

K A 3 A H O B A

(насторожившись)

Нет, Рим

Нам может быть опасен. Едем в Парму!

Я вас люблю!

А Н Р И

Прелестные слова!

K A 3 A H O B A

А вы меня не любите!

А Н Р И

...И губы...

K A 3 A H O B A

Я никогда так страстно не любил,

Так никогда любить уже не буду...

А Н Р И

(глубоко-серьезно)

Так - никогда, тысячу раз - иначе:

Страстнее - да, сильнее - да, страннее - нет.

K A 3 A H O B A

Что смотрите?

\section{А Н Р И}

Прелестные глаза!

Да, их должно быть целовать прелестно... 
Казанова тянется.

А Н Р И

(смеясь и отстраняясь)

Нет, нет, - как лунный луч: когда заснут.

Не забывайте: мы - авантюристы:

Сначала деньги, а потом - любовь.

K A 3 A H O B A

(падая с облаков)

Какие деньги?

\section{А Н Р И}

(играя в серьезность)

За любовь. Но долгом

Своим считаю вас предупредить:

Никак не ниже десяти цехинов.

K A 3 A H O B A

Тысячу!

А Н Р И

Мало!

K A 3 A H O B A

С этим перстнем!

\section{А Н Р И}

Мало!

K A 3 A H O B A

Тысячу - цепь - и перстень... 


\section{А Н Р И}

Мало!

K A 3 A H O B A

Чертов

Вчерашний проигрыш! - И пряжки!

А Н Р И

Мало!

K A 3 A H O B A

(в отчаянии)

И этот ларчик!

А Н Р И

Мало! Мало! Мало!

K A 3 A H O B A

Что же вы потребуете?

А Н Р И

(упираясь кончиком пальца в грудь Казановы)

- Душу

Сию - на все века, и эту

Турецкую пистоль - на смертный выстрел.

(Разглядывая пистоль.)

Турецкая?

K A 3 A H O B A

(как во сне)

Да, да...

А Н Р И 
Даешь?

K A 3 A H O B A

(так же)

Даю.

А Н Р И

(по-детски)

И не отнимешь?

K A 3 A H O B A

Нет...

А Н Р И

(грозя пальцем)

Ну-ну, мессэре!

Чтоб у меня не плакаться потом,

Что плата высока не по товару!

Нагнитесь.

Казанова склоняет голову.

Этот первый поцелуй

В безумный лоб, чтоб мудрым был и добрым.

Давайте - шаг за шагом - постепенно:

Как Бог велел: сначала в лоб, потом в глаза...

K A 3 A H O B A

(яростно)

Когда же в губы?!

А Н Р И

(серьезно) 
Слушайте, дружочек!

Бог дивный мир свой сотворил в неделю.

Женщина - сто миров. Единым духом -

Как женщиной мне стать в единый день?

Вчера гусар - при шпорах и при шпаге,

Сегодня - кружевной атласный ангел,

А завтра - может быть - как знать? Кто знает?!.

K A 3 A H O B A

(сжимая кулаки)

Ты поклялась свести меня с ума!

(Стук в дверь, - он, бешено)

Кто там?!

ГО Л О С 3 А Д В Е Р Ь Ю

Из модной лавки Санта-Кроче.

\title{
А Н Р И
}

(приподымаясь на цыпочки)

Поцеловали в лоб - целуем в очи!

Входит Хозяйка, за ней две мастерицы.

\author{
Х О 3 Я Й К А \\ (проталкиваясь, мастерицам) \\ Я первая! Нельзя же разом! \\ Привет, синьоры!
}

K A 3 A H O B A

В добрый час!

Уже синьора заждалась. 
Х О 3 Я Й К А

А я - нести надорвалась!

Три ражих девки над заказом

Три ночи не смыкали глаз.

Дорина обливалась потом,

С Джаниной сделалась икота,

Но разыграли, как по потам

Сонату, - бисер - не работа!

Где же синьора наша?

К А Э А H O B A

(на Анри)

- Вот.

Х О З Я̆ К А

Где?

K A 3 A H O B A

Bот.

Х О З Я Й К А

Веселый у господ

Был, верно, ужин?

K A 3 A H O B A

Говорят вам,

Что - вот!

Х О 3 Я ЙК А

Клянусь священной клятвой,

Что не синьору видит взгляд мой...

А - ну совсем наоборот. 


\section{К А Э А Н O В А}

А чтобы спор покончить скоро, -

Синьора, утомивши взоры

Непостоянством женских мод,

Кинула чепчик в огород

И порешила быть - синьором!

Х О 3 Я Й К А

Да, да,- как раз наоборот!

(Мастерицам.)

Ну, дети, это авантюра!

(Казанове.)

Но как же, сударь? Белокура...

Синьора. Та была черна

И - ох!- куда полней фигурой...

И ликом - что твоя луна!

Не спутала же я... Едва ли.

K A 3 A H O B A

(с деланным смехом)

Кругом запуталась, швея!

Х О ЗЯ Й К А

(с жаром)

Ну как же, сударь? Полным ртом

Ее вы в лавке целовали,

Еще Розиной называли:

"Розина, родинка моя!.."

\section{А Н Р И}

(в воздух)

Заказанный для темных глаз 
Атлас - теперь послужит светлым.

Жизнь поклялась: все будет пеплом...

(Кладя руку на плечо Казановы.)

Дружочек, не сержусь на вас.

1-я М А С Т Е Р И Ц А

И ни слова укора!

2-я М А С Т Е Р И ЦА

И ни капельки злобы!

Х О ЗЯ Й К А

(разгружая картонки)

Какие уборы, синьора!

Четыре робы, синьора!

1-я М А С Т Е Р ИЦА

Не плачет!

2-я М А С Т Е Р И ЦА

Не бесится!

K A 3 A H O B A

Генриэтта! - Анри!

А Н Р И

(над платьями)

Одно - цвета месяца,

Другое - цвета зари!

Х О $3 Я \breve{~ К ~ А ~}$

(продолжая)

Косынки! Мантилий! 


\section{А Н Р И}

Ваш подарок - блестящ.

Одно позабыли вы:

Цвета Времени - Плащ.

Так, большими ударами

Жизнь готовит нам грудь...

Х О $3 Я \breve{~ К ~ А ~}$

Довольно думать, сударыня,

Будемте мерить, сударыня...

\section{А Н Р И}

(в пространство)

Плащ тот пышен и пылен,

Плащ тот беден и славен...

Х О $3 Я \breve{И ̆ ~ А ~}$

(держа на весу платье)

Здесь возьмем, там убавим,

Тут ушьем, там зашпилим...

Анри, Хозяйка и мастерицы выходят.

\section{K A 3 A H O B A}

Тысячу громов! - Это нрав! - Я прав! -

Не торговка, а чертовка! - Но Анри! - Как сталь!

И бровью не повела! - Ну, дела! - Хвала

Господу в небесах - за любовь! - Кто там!?

ГО Л О С 3 А Д В Е Р Ю Ю

Вчерашний капитан. 
K A 3 A H O B A

Ах, это вы? Взойдите.

\section{К А ПИ Т А Н}

(входя)

Хотелось мне по поводу событий

Вчерашних - по душам - как друг -

потолковать.

Вы разрешаете, мессэре?

\section{K A 3 A H O B A}

Весь вниманье.

\section{К А П И Т А Н}

Сие созданье любит вас.

\section{K A 3 A H O B A}

(вспыхнув)

Созданье

Сие - невеста мне!

\section{К А ПИ Т А Н}

(невозмутимо)

Должно быть, мать

Что ль у нее до времени скончалась,

Иль просто колыбель ее качалась

Под бурным небом,- словом, быль темна.

Послушна как дитя, добра, умна,

Старик Гораций ей слагал бы оды! -

Но вдруг мужскую надевает моду,

По окнам бродит, как сама Луна,

Трезва за рюмкой, без вина - пьяна... 
K A 3 A H O B A

(угрожающе)

Нельзя ли поучтивей, старина?

К А П И Т А Н

(невозмутимо)

То в честь Платона составляет вирши,

То - молнией в седло.- Куда? - Приказ!

Жду час, жду два.- Влетает.

K A 3 A K O B A

Hy?

К А ПИ Т А Н

Дралась

С польским временщиком - за командиршу!

K A 3 A H O B A

Как в руки вам достался этот клад?

К А ПИ Т А Н

Я жил тогда, недели три назад,

В Чивите-Веккии, в гостинице...

(Щелкает пальцами.)

K A 3 A H O B A

Да шут с ней,

С гостиницей!

К А П И Т А Н

И вот, с косичкой куцей -

Гусар по лестнице, за ним - 
(пауза, и блаженно)

- еще гусар.

Вы хороши, я - нет. Вам двадцать лет, я стар,-

Но молод или нет,- всяк вправе быть убитым!

Сражен!- Заворожен!- Железняком к магниту

Тянусь. Тот впереди, а наш Анри за ним.

Сигарный дым прошел,- но в сердце что за дым

Пошел, когда она, ресниц скосивши стрелы,

Меня, как невзначай, своим плащом задела...

K A 3 A H O B A

А дальше?

\section{К А П И Т А Н}

Дальше - вот: из двух окон моих

Все видно в их окне. Не муж и не жених

Он ей, но и не брат,- да вовсе ей не нужен!

За ужином сидят,- похороны, не ужин!

Молчат и не едят,- не разжимают губ.

Другой уходит спать.

...Я, может, груб и глуп,-

Зову слугу: гляди!- Тот смотрит, рот разинув.

- Зови ее ко мне!

K A 3 A H O B A

Черт!

К А П И Т А Н 
За десять - цехинов!

K A 3 A H O B A

Пришла?

К А П И Т А Н

Пришла.- Выходим в парк.

Отсчитываю ей монеты.

Смеется:- Думаете, нету

Цехинов у меня?- и шварк

Мне под ноги кошель!

K A 3 A H O B A

Богиня!

К А П И Т А Н

Так и не ведаю поныне,

Мессэре, что ее за змей

Ужалил. - Окончанье просто:

Тот спал, а парочку друзей

В Чезену повезла повозка.

С тех пор не расстаемся.

K A 3 A H O B A

Tak.

А кто она? Откуда? 
К А П И Т А Н

Мрак.

Туман. Обман.- Роман, быть может.

Быть может, злостный опекун,

Иль зверский муж,- ей мало лун,

Но этот век безумно прожит!

\section{ГЕНРИЭ Т Т А}

(входя)

Позвольте мне вас потревожить...

Казакова и Капитан встают, столбенеют.

Синьоры...

К А П И Т А Н

Молния и мрак!

Санкта Мадонна! - Конь и шпоры!

Ах я подлец! Ах я дурак!

Х О З Я Й К А

Ну, как вам нравится синьора?

1-я М А С Т Е Р И ЦА

Конфетка!

2-я М А С Т Е Р И Ц А

Ангел!

1-я М А С Т Е Р И ЦА 
Божья мать!

К А ПИ Т А Н

Как быть? - Куда глаза девать?

X О 3 Я Й К А

(с ложной скромностью)

Не правда ли, для первой пробы -

Недурно?

K A 3 A H O B A

(только что очнувшись)

Сонм небесных сил!

X О 3 Я Й К А

Клянусь, никто домашней робы

С таким величьем не носил!

К А ПИ Т А Н

Отныне ни вина, ни карт.

Х О

(принимая от Казановы кошелек)

Какие звонкие цехины!

Сейчас июнь.

(Казанове) 
Пусть подарит вам март

Такую дочку.

(Генриэтте)

Вам - такого сына.

Хозяйка и мастерицы, приседая, выходят .

К А ПИ Т А Н

(со вздохом)

Им вслед, любезные друзья,

Со вздохом подымусь и я.

ГЕНРИЭ Т Т А

(светски)

Так скоро?

K A 3 A H O B A

Отчего так спешно?

К А ПИ Т А Н

Что делать,- срочные дела!

(Казанове)

Мне ваша молодость мила.

(Генриэтте)

Я ваш поклонник - неутешный.

(Выходит.)

K A 3 A H O B A

(надевая Генриэтте кольцо) 
Сегодня колечко, а завтра - запястье.

ГЕНРИЭ Т Т А

(в тон)

Сегодня безумье, а завтра - бесстрастье.

K A 3 A H O B A

Смотрите-за новым

К другим Казановам

В окошко не лазьте!

ГЕНРИЭ Т Т А

Я больше не вор и не кошка, -

Я ваша раба.

K A 3 A H O B A

Судьба ты моя! Роковое и грустное счастье!

Молчание.

K A 3 A H O B A

Генриэтта?

ГЕНРИЭ Т Т А

Казанова? 
K A 3 A H O B A

Взгляд опущен...

Ты не счастлива?

ГЕНРИЭ Т Т А

Я счастлива - но тихо.

Мне когда-то на кофейной гуще

В нашем замке нагадала лесничиха...

K A 3 A H O B A

В вашем замке?

\section{ГЕНРИЭ Т Т А}

Я ошиблась... Я случайно...

Ты не слушай...

K A 3 A H O B A

Генриэтта, где твой замок?

Кто ты?

ГЕНРИЭ Т Т А

Тайна.

K A 3 A H O B A

Ты не скажешь? 


\section{ГЕН РИЭ Т Т А}

Тайна,

Казанова! - А кофейное гаданье -

Только сонное ворчанье глупых мамок.

K A 3 A H O B A

Ты не веришь, верно, думаешь - я грубый,

Буду нежным, буду страшно осторожным.

Волком был, а буду шелком. - Можно

В этот локон мне поцеловать вас?

Г ЕНРИ Э Т Т А

(закрывая глаза)

В губы! 


\section{КАРТИНА ТРЕТЬЯ}

ВИОЛОНЧЕЛЬ

Терраса загородного дома в Парме. Ночь. Ступени в сад.

1-й Ф Р А Н ЦУ 3

Престранный праздник... Кавалеров-тьма,

А дам у нас...

(Глядит на Генриэтту, беседующую с Педантом.)

2-й Ф Р А Н Ц У 3

Не может быть на небе

Двух лун...

1-й $Ф$ Р А Н Ц У 3

Но звезды есть, кроме луны.

Прелестна - и до странности похожа

На лунный свет...

2-й Ф Р А Н Ц У 3

И на какой-то сон...

1-й Ф Р А Н Ц У 3

Никто друг другу не представлен.

2-й $Ф$ Р А Н ЦУ 3

Ясно, 
Хозяин наш чудак - к тому горбун -

K тому влюблен - и вовсе не намерен,

Инкогнито ее раскрыв, стада

Вздыхателей к дверям ее пригнать...

\section{1-й $Ф$ Р А Н Ц У 3}

A тот

С ней рядом, сух и жгуч, как адский уголь, -

Кто он?

\section{2-й Ф Р А Н Ц У 3}

Что за вопрос! Конечно, друг,

Не муж, конечно...

(Всматриваясь в Казанову.)

Я как будто где-то

Его встречал... Ну да - конечно, тот,

Что банк сорвал... Фарусси, иль Ферусси...

(Беседуя, отходят.)

Г О Р Б У Н

(подходя к Генриэтте и Педанту)

Небесная, как нравится вам ваш

Ученый собеседник?

ГЕНРИЭ Т Т А

Собеседник? 
Нескромным словом этим как дерзну

Сей столп премудрости назвать, пред коим

Колена клонятся мои...

П Е Д А Н Т

Когда б

Сам Цицерон через летейски воды

Обратный путь свершив, древесный свод

Сей огласил прекрасными речами,-

Клянусь, не отразил бы этот свод

Краснее речи...

ГЕНРИЭ Т Т А

Вы меня смутили.

П Е Д А Н Т

(с поклоном)

Учтивейшая всех подлунных жен,

Послушайте Педанта-Кавалера:

Во образе прелестном сем смущен

Не только Цицерон - сама Венера!

(Отходит.)

Г О Р Б У H

А что вы скажете на этот сад, -

Убежище хотя и не Амура,

(Тому виною горб!),- но девяти

Сестер бессмертных, коим вы десятой

Сестрой являетесь... 
ГЕНРИЭ Т Т А

Сей сад затмил

Навек в моих глазах сады Версаля.

Г О Р Б У

(оживленно)

Вы знаете Версаль?

\section{ГЕНРИЭ Т Т А}

(прохладно)

Да, да, слегка,

Проездом...

Г О Р Б У

Вспоминаю, что синьора

При нашей встрече в Опере - число

В сем сердце запечатлено - пристрастье

К медалям обнаружила...

\section{ГЕНРИЭ Т Т А}

\section{Страстна}

Я ко всему, что вечно.

Г О Р Б У $\mathrm{H}$

Буду льстить

Себя надеждой, что мои Челлини 
Заслужат то, чего - виновен горб! -

Я заслужить - себе надеждой нежной

Не льщу: улыбки.

\section{ГЕНРИЭ Т Т А \\ (указывая на Казанову)}

Разрешите мне

И кабалеро пригласить...

\section{Г О Р Б У $\mathrm{H}$}

(язвительно)

\section{Пристрастен}

Он также к ним?

\section{ГЕНРИЭ Т Т А}

(отчетливо)

Пристрастен он - ко мне,

А я - к нему. Идемте, кабалеро!

Генриэтта, Казанова и Горбун выходят.

\section{1-Й И С П А Н Е Ц}

Хозяин по уши влюблен!

\section{2-й И С П А Н Е Ц}

(намекая рукой на рост Горбуна)

Нетрудно

И выше головы! Клянусь плащом 
И шпагою гидальго: кроме шпаги

Bce - за единый взгляд!

\section{1-Й И С П А Н Е Ц}

Напрасен труд!

Подходят, беседуя, П о с о л и с п а н с к и й

и Посол французский.

П О С О Л ИС П А Н С КИ Й

О чем так горячо?

П О С О Л

Чей труд?

1-й И С П А Н Е Ц

Извечный

Прекрасный труд испанца: покоренье

Того, что непокорно. Нынче - той.

П О С ОЛ ИС ПАНСКИ Й

Ах, вы о нашей дивной чужестранке!

Но почему так безнадежно?

1-й И С П А Н Е Ц

Дон

Антонио, когда в теченье часа 
Красавица ни разу не вздохнет

Всей грудью - значит, счастлива, и значит,

Не нужно ей ни вас - ни вас - ни вас -

(на себя)

Ни вашего слуги, ни всей вселенной, -

Ни самого инфанта...

2-й И С П А Н Е Ц

Тише, тише!

Горбатые хитры и слышат все.

Оба испанца отходят.

П О С ОЛ ИС П А Н С К Й

А кто она?

П О С О Ф Р АНЦУ 3 СК ИЙ

Отнюдь не итальянка.

Сей стройный рост и заводь чудных этих глаз,

Зовя - отказывающих...

(С улыбкой.)

Да что нам

До родины ее, когда одна

У всех красоток родина: та пена,

Из коей нам Венера поднялась!

- А кто ее Парис? 
П О С ОЛ ИС П А Н С И Й

Какой-то плут.

Аббатишко разжалованный, мастер

Ловить Фортуну за конец плаща!

Ну и глазищи у него!

П О С О Л

А кожа!

Как будто черным вспоен молоком.

Но я в мужчинах - не знаток. В красотках

Мы знаем толк, в нас знают толк - они.

Явление Генризтты об руку с Горбуном.

П О С О Л И П А Н С К ИЙ

Вулкан с Венерой!

П ОСОЛ ФРАНЦУ З СКИ Й

Нет, скорей Диана

С плененным фавном!

Г О Р Б У Н

Возвращаю вам

Восьмое чудо мира - нашу Музу!

П ОСОЛ ФРАНЦУ

Я б единицей стройной заменил 
Восьмерку, друг,- и - таковы французы! -

Я "Дамой сердца" заменил бы Музу.

ГЕНРИЭ Т Т А

(взглядывая на Казанову)

Умею быть и Дамою Души.

П ОС ОЛ ФРАНЦУ З С ИЙ

А разве это - не одно и то же?

\section{ГЕ Н РИЭ Т Т А}

Секундной стрелкой сердце назову, А душу - этим звездным циферблатом!

Г О Р Б У Н

Божественно!

П Е Д А Н Т

Отменно!

П О С О Л

И остро!

П Е Д А Н Т

Вы как Спиноза - на любой вопрос

Имеете ответ. 
ГЕНРИЭ Т Т А

(смеясь)

Сентябрь - месяц

Мне вместо колыбели дал

(взглядывая в небо)

- Весы.

Мои ж часы, любезные друзья,

Заведены часовщиком Спинозой.

Из сада доносятся первые жемчужины менуэта.

ГЕНРИЭ Т Т А

(Казанове)

Прислушайтесь, Джакомо! - Менуэт!

Мой друг и рыцарь, становитесь в позу.

П Е Д А Н Т

Небесная, я вам сплету сонет,

Где рифма встретится "Спиноза" с рифмой

"Роза".

Менуэт.

П О СОЛ ИСПАНСКИЦ̆

Что мне бахромчатая шаль

Испании! 
П Е Д А Н Т

Впервые жаль

Педанту, что взамен наук

Па - не усвоил - менуэта!

Г О Р Б У Н

Проклятый горб мой!

K A 3 A H O B A

Генриэтта!

П О С ОЛ ФРАНЦУ 3 С К Й

Вы возвратили мне Версаль!

Пауза.

Смиренно верю и надеюсь,

Что, этим веером овеясь,

Ваш нежный отдых будет быстр?

ГЕНРИЭ Т Т А

Очаровательный министр!

Вы мне послушны?

П О С ОЛ ФРАНЦУ З С К Й

Есть и буду.

ГЕНРИЭ Т Т А 
Не заносите же причуду

Сию - на черный свой регистр.

Я больше не танцую.

ПОСОЛ

Танец -

За вами.

П Е Д А Н Т

Я как в землю врос!

ПО С О И ИС П А С КИ Й

Нет, даже перед Розой Роз

Не позабуду - что испанец!

(Отходит.)

ГЕНРИЭ Т Т А

Я музыки хочу.

Г О Р Б У H

Желанье

Владычицы - закон. Сюда,

Прекрасный Сандро!

Медленно и нехотя приближается, со своей виолончелью,

Прекрасный Сандро.

Предстоит вам честь 
И счастье быть услышанным синьорой.

Синьора хочет звуков.

П Р Е К Р А С Н Ы Й С А Н Д Р О

Ах,гроза,

Должно быть, близко. Я в каком-то странном

Тумане...

П О С ОЛ ФРАНЦУ З СКИЙ

Где гроза? Взгляните вверх:

Все звезды налицо. Коль не дочтетесь

Одной -

(глядя на Генриэтту)

- Взгляните вниз.

П Р Е К Р А С НЫ Й С А Н Д Р О

Какой-то звон

Мне чудится...

ГЕНРИЭ Т Т А

(участливо)

Вы не больны, надеюсь?

П Р Е К Р А С Н Ы Й С А Н Д Р О

Изнемогаю. Не могу играть.

Г О Р Б У Н 
Диковинные люди - музыканты!

Проси хоть час, хоть год, хоть век...

ГЕНРИЭ Т Т А

(глядя на Сандро, нежно)

На сих

Причудников нельзя сердиться, ибо

Как женщины - играют, как хотят,

Когда хотят - кому хотят...

(Протягивая руку Сандро.)

- Маэстро,

Вы мой союзник...

П Р Е К Р А С Н Ы Й С А Н Д Р О

(склоняясь)

Как струна - смычку.

ГЕНР ИЭ Т Т А

(подходя к виолончели)

Посмотрим, все ли мы с тобою в дружбе,

Виолончель, душа моей души?

(Садится, играет.)

K T O - T O

Сплю или нет?

Д Р У ГО Й 
Нет, это сон нам снится!

И С П А Н С И Й П О С О Л

(хватаясь за сердце)

Как нож!

Ф Р А Н Ц У З С К И Й П О С О Л

(гладя себя вдоль груди)

Как мед!

Г О Р Б У Н

Так добрый дух, скорбя,

Уходит в мир...

П Р Е К Р А С Н Ы Й С А Н Д Р О

(впервые человеком)

Лаири - ученица!

Что вы играли нам?

ГЕНРИ Э Т Т А

(ему)

Свое,-

(взглядывая на Казанову)

- Себя.

Горбун, за секунду до того отозванный слугой, подходит к Генриетте и окружающим ее. 
Г О Р Б У Н

Простите, что прерву очарованье...

K вам посланный с письмом. Не говорит -

Кем послан.

Все отходят.

ГЕНРИЭ Т Т А

Где письмо?

(Не вскрывая.)

- А! Семь печатей!

(Казанове)

Моя любовь,- расстаться мы должны. 


\section{КАРТИНА ЧЕТВЕРТАЯ}

\section{ГОСТИНИЦА "ВЕСЫ"}

Ночь. Дорожный развал. Горит одна свеча. У стола, уронив вниз голову в руки, сидит Казанова, Генриэтта, одетая по-дорожному, в беспокойстве ходит по комнате.

ГЕНРИЭ Т Т А

Который час?

K A 3 A H O B A

За час - который раз

Ты спрашиваешь?

ГЕНРИЭ Т Т А

Нынче ночью встали

Мои часы: должно быть, предпочли

Времени - Вечность: отлетела стрелка!

K A 3 A H O B A

Ты уронила их?

ГЕНРИЭ Т Т А

Нет, это ты

Задел их, сонный.

K A 3 A H O B A

Я не помню. 
Г ЕНР ИЭ Т Т А

\section{Помнишь?}

Еще ты вскрикнул:- Что это за звон?

А я смеясь тебе сказала:- Сердце.

(Глядя на часы.)

Мингер Спиноза, мудрый филозоф,

Но скверный часовщик вы!

K A 3 A H O B A

Генриэтта!

Мы скоро расстаемся. Сядь ко мне,

Как ты любила - хочешь? - на прощанье.

ГЕНРИЭ Т Т А

(качая головой)

Нет.

K A 3 A H O B A

Ты не хочешь?

\section{ГЕНРИЭ Т Т А}

Мало ли чего

Хотим, дружок. Пока живешь - все хочешь -

Всего. Но это Жизнь, а нынче - Смерть.

Солдаты смерть встречают стоя.

Ах, не забыть турецкую пистоль, 
Подарок твой!

K A 3 A H O B A

Мой мальчик! Генриэтта!

Последняя мольба к тебе!

ГЕНРИЭ Т Т А

Изволь.

K A 3 A H O B A

(по-детски)

Ночь глубока, дорожная карета

Так широка, а мы с тобой тонки,

Как два клинка... Клянусь тебе, я слезу

На первом повороте!

ГЕНРИЭ Т Т А

(у окна)

\section{Огоньки}

В домах - везде - погасли...

(Вполоборота - Казакове.)

Бесполезно.

K A 3 A K O B A

Нет у тебя души!

ГЕНР ИЭ Т Т А 
Должно быть - нет.

K A 3 A H O B A

А в жилах - лунный свет.

ГЕНРИЭ Т Т А

Быть может - да,

Быть может - нет.

K A 3 A H O B A

Скажи мне на прощанье:

Бес или ангел ты?

\section{ГЕНР ИЭ Т Т А}

Чужая тайна

Оставим это.

(Глядя на часы.)

Бедные часы!

- И надо же, чтоб именно весы

Щиток гостиницы изображал, где встреча

Вечнейшая кончается навек,

Как тает снег...

(Берясь за сердце.)

Боюсь, что здесь навек 
Покончено с законом равновесья!

(Снимает с руки кольцо, подает его Казанове.)

Возьми назад.

K A 3 A H O B A

(высокомерно)

Ни писем, ни колец

Обратно не беру!

ГЕНРИЭ Т Т А

(как эхо)

Ни клятв, ни писем

Напрасно не храню.

\author{
K A 3 A H O B A \\ (вскипая) \\ Ax - так? \\ ГЕНРИЭ Т Т А \\ (сама с собой)
}

Зачем?

Нет, дорогой, прощаться - так прощаться!

(Пишет что-то кольцом по стеклу, окно настежь, кольцо в ночь.)

Вот и пропало!

K A 3 A H O B A 
(прорываясь)

Хороша любовь!

Из-за каких-то там семи дурацких

Чертовых - черт! - печатей - в ночь - навек...

- Какая там любовь! Так,- приключенье!

ГЕНРИЭ Т Т А

Оставим это. Обещать одно

Мне должен ты. Коль в жизни доведется

Нам встретиться еще - не должен ты

Глазом моргнуть. Вот долг твой. Понял?

K A 3 A H O B A

(желчно)

Понял.

Любовь и долг, но это так же ново...

ГЕНРИЭ Т Т А

(на секундочку А н р и)

Как белый волк - и верный Казанова!

(По-другому)

Еще одно: нигде и никогда

Не смей разузнавать - под страхом смерти

Моей - кто я. Еще одно: люби

Другую, нет - других, нет - всех. Безумства -

Три - свершила я в свой краткий век.

Ты - третье и последнее.- Довольно.

- Который час? 
K A 3 A H O B A

Так ты уйдешь одна?

\section{ГЕНРИЭ Т Т А}

Да, как пришла.

K A 3 A K O B A

Нет, это невозможно!

\section{ГЕНРИЭ Т Т А}

Все можно - под луной!

Лунный луч.

- Гляди, луна

Уж зажигает нам фонарь дорожный...

(Тушит свечу, наклоняется над спинкой кресла, кладет Казакове на голову руки.)

Когда-нибудь, в старинных мемуарах, -

Ты будешь их писать совсем седой,

Смешной, забытый, в старомодном, странном

Сиреневом камзоле, где-нибудь

В Богом забытом замке - на чужбине -

Под вой волков - под гром ветров - при двух свечах...

Один - один - один,- со всей Любовью

Покончив, Казанова! - Но глаза,

Глаза твои я вижу: те же, в уголь 
Все обращающие, те же, в пепл и прах

Жизнь обратившие мою - я вижу...

И литеры встают из-под руки, -

Старинные - из-под руки старинной,

Старинной - старческой - вот этой вот моей...

(Прижимает к рукам его руки.)

Когда-нибудь, в старинных мемуарах,

Какая-нибудь женщина - как я

Такая ж... Но который час?

Казанова молча показывает ей часы.

- Все поздно!

- Даю вам клятву, что тебе приснюсь!

(Затыкает за пояс пистоль. В дверях)

Прощай! - Одна - над тобой и мной

Луна бездомная.

K A 3 A H O B A

(к ней)

Скажи мне!

\section{ГЕНРИЭ Т Т А}

(качая головой)

Все под большой луной

Играем втемную. 


\section{КАРТИНА ПЯТАЯ \\ ТРИНАДЦАТЬ ЛЕТ СПУСТЯ}

Комната гостиницы "Весы", где прощались Генриэтта и Казанова. Входят веселой уличной бурей - Казанова и его тысяча первая подруга.

Д Е В Ч О Н К А

Вы здесь живете?

K A 3 A H O B A

Нынче здесь.

А завтра...

Д Е В Ч О Н К А

Графский вкус!

Святой Исус! Диван, комод

И люстра... Все как у господ!

И пол коврами устлан весь!

-Я только одного боюсь,

Что это все не наяву,

Что вдруг - боюсь - проснусь!

K A 3 A H O B A

Где муж твой?

Д Е В Ч О Н К А

Спят мужья мои! 
K A 3 A H O B A

А как тебя зовут?

Д Е В Ч О Н К А

Мими,

Я ужинать хочу!

K A 3 A H O B A

Люблю

У женщин - аппетит!

Д Е В Ч О Н К А

О, я бы даже королю

Сказала: кто не сыт,

Любить не может!

K A 3 A H O B A

Как с детьми:

Накормишь - и бай-бай!

Д Е В Ч О Н К А

Да, да, сначала накорми,

Потом и обнимай!

K A 3 A H O B A

Чем ужинать мы будем? 
Д Е В Ч О Н К А

\section{Всем!}

Давай, коли даешь!

Пожалуй - и тарелку съем!

А вилку, ложки, нож -

В карман, на память!

K A 3 A H O B A

(позабавленно)

И гусей

В карман, на память?

Д Е В Ч О Н К А

Все в карман!

K A 3 A H O B A

(с комическим вздохом)

Ну что ж, перелистаем сей

Гастрономический роман!

- Так же целуешь ты, как ешь?

Д Е В Ч О Н К A

Целую так, как ем,

Пью как целую - и пою,

Как пью!

K A 3 A H O B A 


\section{Сплошной Эдем!}

Ле-Дюк! Не слышит! - Старый трюк!

Лентяй! - Ле-Дюк! - Наглец! Ле-Дюк!

Л Е - Д Ю К

(просовывая голову в дверь)

Что надо?

K A 3 A H O B A

Надо мне, пострел,

Чтоб ты мне назло спать не смел!

Беги к хозяину, вели-

Да расторопнее, бревно! -

Чтобы тащил сюда вино

И снедь со всех концов земли.

И что иначе, дескать, граф...

Л Е - Д Ю К

Хороший граф!

K A 3 A H O B A

Треклятый нрав!

Л Е - Д Ю К

Такой же граф, как я!

K A 3 A H O B A 
(в ярости)

Убью!!!

(Хладнокровно.)

А что останется - в твою

же пасть перепадет, удав!

Л Е - Д Ю К

Останется тут!

K A 3 A H O B A

Чертов сын!

Л Е - Д Ю К

Каков, мессэре, господин,

Таков слуга.

K A 3 A H O B A

Молчи, наглец!

Л Е - Д Ю К

(разгораясь)

Кто черту - сын, а вы - отец:

Трудами вашими рогат

Весь мир, мессэре! 
K A 3 A H O B A

(полусмеясь)

Шут проклятый!

- Вон!!!

Л Е - Д Ю К

Лондон - Рим - Париж - куда ни

кинешь взгляд-

По всей Европе ваши чертенята!

Казанова пускает в него чернильницей, тот, увернувшись, убегает.

K A 3 A H O B A

(вслед)

Дурак!

(К Девчонке)

- Вздохнула, как во сне...

Взгрустнулось - иль устала слушать?

Д Е В Ч О Н К А

Я думаю о том, что буду кушать

И сколько денег вы дадите мне.

(Задумчиво.)

У тараканов - страшные усы...

Приду домой - пустой чугун и старый веник... 
K A 3 A H O B A

Чего бы ты хотела?

Д Е В Ч О Н К А

Дом. - Часы. -

Лакея в золотом и мно-ого денег!

K A 3 A H O B A

Зачем тебе они?

Д Е В Ч О Н К А

Зачем?

Была ничем, а буду всем.

(Сентенциозно.)

Как цвет нуждается в поливке,

Так нужно денег, чтобы жить, -

Хотя бы для того, чтоб лить

Не сливки в кофий по утрам, а кофий в сливки!

(Трепля на себе юбки.)

Чтобы к чертям вот эти тряпки!

Чтобы катать в своей коляске!

K A 3 A H O B A

(вокруг нее)

Очаровательные лапки!

Очаровательные глазки! 
Д Е В Ч О Н К А

Вздыхатели - так и роятся!

Тот есть тебе несет, тот пить...

(Хлопая в ладоши.)

Чтобы красивеньких - любить,

А над плешивыми - смеяться!

K A 3 A H O B A

Сама Премудрость!

Д Е В Ч О Н К A

Может быть.

K A 3 A H O B A

А сколько лет тебе?

Д Е В Ч О К А

Семнадцать.

- Скорей бы ужин!

K A 3 A H O B A

А потом бай-бай...

Д Е В Ч О Н К А 
Моя кровать была бы голубая,

Нет,- алая! А в головах - Амур,

И чтобы ямочки везде,- ну пухлый-пухлый!

K A 3 A H O B A

Ты, кажется, еще играешь в куклы?

Д Е В Ч О Н К А

(оскорбленно)

Нет, никогда!

K A 3 A H O B A

Признайся, - иногда!

Д Е В Ч О Н К А

Когда была я очень молода,

Тогда играла: в мать и дочку - раньше.

K A 3 A K O B A

А куколку живую хочешь нянчить?

Д Е В Ч О Н К А

Похожую на вас - хочу, на всех -

Нет, не хочу.- Смешно! - И будет квакать,

Как лягушонок!.. Нет, грешно! 
K A 3 A H O B A

Что - грех?!

Всех девушек удел - грешить и плакать, И плакать и грешить, и плакать вновь,

И вышивать потом на церковь ризы...

\section{Д Е В Ч О Н К А}

Я буду звать ее: моя Любовь,

А при крещеньи дам ей имя: Лиза.

(Постепенно переходя в скороговорку.)

А над кроватью был бы балдахин,

Розовым шелком вышит,- всюду кисти!

И я бы в ней спала одна; боюсь,

Когда храпят - и жарко, а хозяйка

Когда б пришла поздравить, я бы ей -

Смотри - вот так - в глаза бы наплевала!

(Плюется.)

Так, так, так, так. Потом бы золотой

В лоб запустила - не один, а тыщу!

Вот-вот-вот-вот - за то, что у ворот

Стужей меня знобила.- Скоро ужин?

А впрочем, чтобы дотерпеть,

Я песенку могу вам спеть.

Хотите?

K A 3 A H O B A 
Спой!

Д Е В Ч О Н К А

Вы не скупой?

Вы мне дадите золотой?

Казанова, смеясь, опускает ей за шиворот несколько монет. Визг.

Д Е В Ч О Н К А

(поет)

Страсть ударяет молотом,

Нежность пилит пилой.

Было веселым золотом,

Станет сухой золой.

Лучше-пока не выцвели

Очи от слезных дел-

Милый, гуляй с девицами,

В розах, как Бог велел!

Много в саду садовников,

Роза в саду-одна!

Дальше сквозь строй любовников

Гонит меня луна...

(Обрывает.)

Короткая песня, а в Рим доведет!

- Хорошая песня?

K A 3 A H O B A 
На розовый рот

Я твой загляделся, на шейку твою...

Д Е В Ч О Н К А

(обиженно)

Как странно, что смотрят, когда я пою!

(Взглядывая в окно.)

- Луна!

K A 3 A H O B A

Богородица всех измен!

Д Е В Ч О Н К А

(мечтательно)

Она голубого цвета...

(Вглядываясь в окно, читает.)

"Забудешь" - а дальше?- "и Ген... и Ген...

Забудешь и Генриэтту!"

K A 3 A H O B A

(подойдя к ней)

Что ты читаешь?

Д Е В Ч О Н К А

То, что на стекле

Написано - нет, здесь, левей - алмазом...

"И Генриэтту?.." 
K A 3 A H O B A

Или я ослеп?!

Гостиница "Весы" - часы - спаси мой разум!

Алмазом по стеклу - кольцом - кольцо!!!

Тринадцать лет назад!!!- Эй, кони, мчите!!!

(Ударяет кулаком по стеклу. Стекло вдребезги. Взрыв ветра.)

Д Е В Ч О Н К А

Какое страшное у вас лицо!

И почему вы так кричите?

K A 3 A H O B A

Что ты? Кто ты? Вон, негодяйка, сгинь!

(В окно.)

Моя Любовь! Мой лунный мальчик!

Д Е В Ч О Н К А

Мне остается лишь сказать: аминь.

И тут же отправляться дальше.

- Еще убьете!

K A 3 A K O B A

(не понимая)

Ты зачем пришла? 
Д Е В Ч О Н К А

(пятясь)

Вы сами звали, обещали ужин...

K A 3 A K O B A

Что! Ужин? - Кроме этого стекла,

Мне - понимаешь? - ничего не нужно!

Стекло выбито, попадает рукой в пустоту.

Д Е В Ч О Н К А

(хныкая)

Сейчас уйду... Сперва введут в беду,

Потом - у-у - выталкивают в спину...

K A 3 A H O B A

Тринадцать лет, Анри, в каком аду!

Платонова родная половина!

Здесь кто-то плачет? - В лунной полосе

Взойдешь, как сон... как сон... и Бог

рассудит...

Д Е В Ч О Н К А

Я понимаю: вы такой, как все,

И никакого ужина не будет.

Прощайте! 
K A 3 A H O B A

(очнувшись)

Ты уходишь?

Д Е В Ч О Н К А

Ухожу.

Я ненавижу вас!

K A 3 A H O B A

Ого! Ты злая!

Д Е В Ч О Н К А

Я вам предоставляю госпожу

Луну, а вас - Луне предоставляю!

Целуйтесь с ней!

K A 3 A H O B A

Рассерженный зверек!

Д Е В Ч О Н К А

Не смейте на меня глядеть!

K A 3 A H O B A

(позабавленный)

Чертенок!

Хочу - гляжу! 
Д Е В Ч О Н К А

А все равно не впрок!

K A 3 A H O B A

Ну и состарься без таких девчонок!

Д Е В Ч О Н К А

Я так хотела вас любить!

K A 3 A H O B A

Ну-ну!

Еще захочешь!

Д Е В Ч О Н К А

Чтоб взбесились вдруг вы?

K A 3 A H O B A

(хлопая себя по колену)

Садись сюда-хоп!

Д Е В Ч О Н К А

(уже на камнях)

Больше на Луну

Глядеть не будешь - и на эти буквы?..

А что это за буквы?- Нет, в окно 
Не смей глядеть! - Души моей мученье!

(Поворачивает руками его голову к себе.)

- Так что это за буквы?

K A 3 A H O B A

Так,- одно -

Единственное - приключенье.

Д Е В Ч О Н К А

Амурное?

K A 3 A H O B A

Нет, нет...

Д Е В Ч О Н К А

Ну да, ну да!

Знаем мы вас! - Дверь на задвижку запер?

Ужинать не хочу.

(Одним прыжком с колен Казановы к статуэтке Мадонны.)

А шаль - сюда,

Чтобы не огорчалась Божья матерь. 


\section{BIBLIOGRAFIA}

OBRAS DE MARINA TSVETÁEIVA

ЦВЕТАЕВА, Марина. Издранные произеведенияю. Минск: Mastatskaia Literatura, 1984.

. Избранное, Москва: Книжний Клуб, 2012.

. Вольный проезд. Москва: Азбука Классика, 2010.

. Век мой громкий, Москва: ПрозаиК, 2012.

. Конец Казановы. Москва: Азбука Классика, 2010.

. Повесть о Сонечке. Москва: Азбука Классика, 2010.

TSVETAEVA, Marina. Romantika. Tradução e apresentação de Hélene Henry. Paris:

Gallimard, 1998.

TSVETÁIEVA, Marina. Depois da Rússia, trad. Nina Guerra e Filipe Guerra. Lisboa:

Relógio d'Água, 2001.

- Indícios flutuantes. Seleção, tradução e apresentação de

Aurora F. Bernardini. São Paulo: Martins Fontes, 2006.

- Vivendo sob o fogo. Seleção, organização e prefácio de

Tzvetan Todorov. Tradução do russo e do francês de Aurora F. Bernardini. São Paulo:

Martins Fontes, 2008.

\section{Obras SObRe MARINA TSVETÁEIVA}

ALMEIDA, Paula Costa Vaz de. O meu Púchkin de Marina Tsvetáeiva: tradução e apresentação. Dissertação de Mestrado, FFLCH/USP, 2008.

BERNARDINI, Aurora F. Indícios flutuantes em Marina Tzvetáieva. Tese de livredocência, FFLCH/USP, 1976.

BRODSKY, Joseph. "Footnote to a poem" in Less than one: selected essays [1986]. Londres: Peguin Moderns Classics, 2011, p. 195-267. 
CIEPIELA, Catharin. The Same Solitude: Boris Pasternak and Marina Tsvetaeva. Cornell University Press, 2006.

DINEGA, Alyssa W. A Russian Psyche: The Poet Mind of Marina Tsvetaeva. Wisconsin: University of Wisconsin Press, 2001.

FEILER, Lily. Marina Tsvetaeva: The Double Beat of Heaven and Hell. Raleigh: Duke University Press Books, 1994.

KARLINSKY, Simon Marina Tsvetaeva: The Woman, her World, and her Poetry (Cambridge Studies in Russian Literature). Cambridge University Press, 1986.

MAKIN, Michael. Marina Tsvetaeva: The Poetics of Appropriation. Oxford: Clarendon Press, 1993.

SMITH, Alexandra. "Wrinting as a Performance: The Case of Marina Tsvetáieva" in New Zeland Slavonic Journal, 2003, p. 143-53.

TODORÓV, Tzvetan. A beleza salvará o mundo - Wilde, Rilke e Tsvetaeva: os aventureiros do absoluto, trad. Caio Meira. São Paulo: Difel, 2011.

TORLONO, Zara M. Soul and Passion: Marina Tsvetaeva's Classical Plays: Ariadna \& Phaedra. Staroe Vino, 2012.

VILA-MATAS, Enrique. “La galaxia Tsvetáieva” in Letras libres. Cidade do México: Vuelta, n. 14, fev/2000.

\section{GERAL}

ADORNO, Theodor W. "Sinais de pontuação". In: Notas de Literatura I. Tradução e apresentação Jorge M. B. de Almeida. São Paulo: Duas Cidades/34, 2003.

AKHMÁTOVA, Anna A. Antologia poética, trad. e apresentação de Lauro Machado Coelho. Porto Alegre: LPM, 2003.

ANDRADE, Homero Freitas de. "A vida do senhor Bulgákov”. In: $O$ diabo solto em Moscou. São Paulo: Edusp, 2002.

ARMSTRONG, Rebecca. Cretan Woman: Pasiphae, Ariadna, and Phaedra in Latin Poetry. Oxford: Oxford University Press, 2006.

AUERBACH, Erich. Mimesis. A representação da realidade na literatura ocidental. São Paulo: Perspectiva, 1971. 
BAKHTIN, Mikhail. Problemas da poética de Dostoiévski, trad. Paulo Bezerra. Rio de Janeiro: Forense-Universitária, 1981.

BRITTO, Paulo Henrques. A tradução literária. Rio de Janeiro: Civilização Brasileira, 2012.

BULFINCH, Thomas. O Livro de Ouro da Mitologia - Histórias de Deuses e Heróis. Rio de Janeiro: Ediouro, 2006.

BYRON, L. Dom Juan. Londres: Penguin Classics, 2004.

CASANOVA, Giacomo. Memorias. Madri: Aguilas Ediciones, 1982.

CAVALIERE, Arlete. O inspetor geral de Gógol/Meyerhold: um espetáculo síntese. São Paulo: Perspectiva, 1996. . "A arte do discurso: a paródia" in Nicolai Gógol, $O$ nariz \& A terrível vingança. São Paulo: Edusp, 1990.

. Teatro russo: percurso para um estudo. São Paulo:

Humanitas, 2009. . "Nota à presente edição" e "O teatro de Maiakóvski: mistério ou bufo?" in Vladímir Maiakóvski, Mistério bufo, trad. Arlete Cavaliere. São Paulo: $34,2012$. ; VÁSSINA, Elena (orgs.). Teatro russo: literatura e espetáculo. São Paulo: Ateliê, 2011. ; VÁSSINA, Elena; SILVA, Noé (orgs.). Tipologia do simbolismo nas culturas russa e ocidental. São Paulo: Humanitas, 2005.

CHEVAlLIER, Jean J.; GHEERBRANT, Alain. Dicionário de símbolos. Rio de Janeiro: José Olympio, 2012.

COELHO, Lauro Machado. Anna, a voz da Rússia: vida e obra de Anna Akhmátova. São Paulo: Algol, 2008.

DIDEROT, Dennis. Discurso sobre a poesia dramática, trad. Franklin de Matos. São Paulo: Cosac Naify, 2006.

FALEIROS, Álvaro. Traduzir o poema. São Paulo, Ateliê, 2012.

FIGES, Orlando. A tragédia de um povo. A revolução Russa 1891 - 1924. Tradução de Valéria Rodrigues. Rio de Janeiro: Record, 1999.

, O. Natasha's dance: a cultural history of Rússia. Londres: Penguin Books, 2002. 
GUINSBERG, Jacó. Stanislávski e o teatro de arte de Moscou. São Paulo: Perspectiva, 2001.

, J. Stanislávski, Meierhold \& Cia. São Paulo: Perspectiva, 2001.

HUTCHEON, Linda. Uma teoria da paródia: ensinamentos das formas de arte do século XX, trad. Tereza Louro Pérez. Lisboa/Rio de Janeiro: Edições 70, 1989.

JAKOBSON, Roman. A geração que esbanjou seus poetas. Tradução e posfácio de Sônia Regina Martins Gonçalves. São Paulo: Cosac Naify, 2006.

KELLY, Ian. Casanova: muito além de um grande sedutor, trad. Roberto Franco Valente. Rio de Janeiro: Zahar, 2008.

MAGALDI, Sábato. O texto no teatro. São Paulo: Perspectiva, 2008.

MELO E SOUSA, Antonio Candido; ROSENFELD, Anatol; PRADO, Décio de A.; GOMES, Paulo Emílio S. A personagem de ficção. São Paulo: Perspectiva, 2007.

MONTEFIORE, Simon Sebag. Stálin: a corte do czar vermelho, trad. de Pedro Maia Soares. São Paulo: Companhia das Letras, 2006.

PAZ, Octavio. Os filhos do barro, trad. Ari Roitman e Paulina Wacht, São Paulo: Cosac Naify, 2013.

POMORSKA, Krystyna. Formalismo e futurismo. Tradução de Sebastião Uchoa Leite. São Paulo: Perspectiva, 1972.

ПУШКИН, Александр. Евгений Онегин, Москва: Ексмо, 2012.

PÚCHKIN, Aleksandr S. Eugênio Oneguin. Tradução de Dário Moreira de Castro Alves. Rio de Janeiro: Record, 2010.

A. Boris Godunov. Tradução de Irineu Franco Perpétuo. Rio de Janeiro: Globo, 2007.

A. Pequenas tragédias. Tradução de Irineu Franco Perpétuo. Rio de Janeiro: Globo, 2006.

RIPELLINO, Angelo Maria. O truque e a alma. São Paulo: Perspectiva, 1996. A. M. Maiakóvski e o teatro de arte de vanguarda. São Paulo:

Perspectiva, 1986.

ROSENFELD, Anatol. O teatro épico. São Paulo: Perspectiva, 2006. A. Texto/Contexto I. São Paulo: Perspectiva, 1996. , A. Texto/Contexto II. São Paulo: Perspectiva, 2006.

ROSTAND, Edmond. L'Aiglon. Paris: Gallimard, 1986. 
RYNGAERT, Jean-Pierre. Introdução à analise do teatro. Tradução de Paulo Neves. São Paulo: Martins Fontes, 1996.

SCHNAIDERMAN, Boris. Os escombros e o mito - a cultura e o fim da União Soviética. São Paulo: Companhia das Letras, 1997. , B. Tradução, ato desmedido. São Paulo: Perspectiva, 2011.

TOLEDO, D. de O.; FILIPOUSKI, A. M. R. (orgs.) Teoria da Literatura. Formalistas Russos. São Paulo: Globo, 1978.

TOMACHEVSKI, B. V. Teoriia Literatury. Poetika. Moscou: Aspent Press, 1999.

TINIANOV, I. O problema da linguagem poética. Rio de Janeiro: Tempo Brasileiro, 1975.

VÁRIOS AUTORES. Poesia russa moderna, trad. de Augusto de Campos, Haroldo

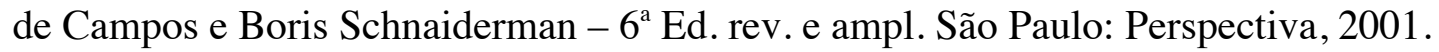
VÁRIOS AUTORES. Cadernos de Literatura de Cultura Russa, vol. 1. Curso de Russo. DLO/FFLCH/USP. São Paulo: Ateliê, 2004.

WATT, Ian. Mitos do individualismo moderno. Tradução de Mario Pontes. Rio de Janeiro: Zahar, 1997. 